\title{
The United Nations Charter As Constitution of The International Community
}

\author{
BARDO FASSBENDER ${ }^{*}$
}

The Charter of the United Nations (the Charter) was brought into existence in the form of an international treaty. In the course of the last fifty years, however, the "constitutional predisposition" of the Charter has been confirmed and strengthened in such a way that today the instrument must be referred to as the constitution of the international community. In this Article, the Author suggests that the Charter is the constitution of the international community in its entirety, i.e., in all subjects of international law, and that such an understanding of the Charter has significant repercussions for its legal status, interpretation, amendment, and possible future reform. The Article first discusses how the concept of a constitution has been used with regard to the modern state. The Author next presents writers who have made consistent use of "constitutional" models in international law. The Article then explains why the concept of a constitution can be applied to bodies other than states and discusses the relationship between the international community and an international constitution. Next, the Article distinguishes the constitutional law of the international community from "general international law," jus cogens, and obligations erga omnes. Finally, the Author outlines a number of consequences of the constitutional approach with particular emphasis placed on the admission and expulsion of members.

I. INTRODUCTION ......................... 531

II. "CONSTITUTION" AND ITS ASSOCIATION WTTH THE MODERN

STATE ............................ 532

* Lecturer in Law, Humboldt University, Berlin, Germany. Many ideas set out in this article are elaborated on in the author's forthcoming book U.N. SECURITY COUNCIL REFORM AND THE RIGHT OF VETO: A CONSTITUTIONAL PERSPECTIVE, to be published by Kluwer Law International, The Hague. If not otherwise indicated, translations are provided by the author. 
III. THE TRANSFER OF THE CONSTITUTIONAL IDEA INTO THE SPHERE OF INTERNATIONAL LAW: DIFFERENT APPROACHES

..... 538

A. Unsystematic Ways of Using Constitutional Language ...................... 538

B. Alfred Verdross and his School .............. 541

C. The New Haven School . . . . . . . . . . . . . . . . 544

D. The Doctrine of International Community ....... 546

IV. THE INTERNATIONAL COMMUNITY AND ITS CONSTITUTION 551

A. A Contested Notion ................... 553

B. The Traditional Dichotomy Between "The International" and "The Constitutional" ............ 555

C. International Community and International Constitution ....................... 561

D. International Community, Constitution, and Organization ................... 561

V. The U.N. Charter as A Constitution . . . . . . . . . 568

A. The "Ideal Type" of a Constitution ............. 569

B. Constitutional Characteristics of the U.N. Charter

.......................... 573

1. A "Constitutional Moment" ............. 573

2. System of Governance ............ 574

3. Definition of Membership ........... 576

4. Hierarchy of Norms ............... 577

5. "Eternity" and Amendment ........... 578

6. A "Charter" ... . . . . . . . . . . . . . . . . . . 579

7. Constitutional History ............. 580

8. Universality and the Problem of Sovereignty ... 581

VI. Conceptual Distinctions $\ldots \ldots \ldots \ldots \ldots \ldots \ldots \ldots . \ldots 85$

A. Constitutional Law and "General International Law" .......................... 585

B. "Constitutional By-Laws" of the International Community .................... 588

C. Constitutional Law, Jus Cogens, and Obligations

Erga Omnes ....................... 589

VII. Consequences ......................... 593

A. Non-Member States . . . . . . . . . . . . . . 593

B. The Charter as a Living Instrument ........... 594 
C. Constitutional Interpretation ............ 595

D. Constitutional Amendment ............. 598

E. Freedom and Restraint of Security Council Reform ......................... 606

F. Legal Persons Other than States as Addressees of Security Council Decisions ... . . . . . . . . . . . . 609

G. Admission and Expulsion of U.N. Member States . . . 610

VIII. Conclusion ..................... 616

Failing to recognize itself as a society, international society has not known that it has a constitution. Not knowing its own constitution, it has ignored the generic principles of a constitution.'

The arch from the by-gone era to the new is being built... . The all-important question: will it hold? ${ }^{2}$

\section{INTRODUCTION}

The Charter of the United Nations was brought into existence in the form of an international treaty. It was felt, however, that just calling the Charter a treaty, placing it on a level with thousands of other international agreements, would not do justice to its outstanding importance in postwar international law. Its substance was better understood by President Harry S. Truman when he compared the Charter in the final session of the San Francisco Conference to a constitution that grows and develops and expands as time goes on. ${ }^{3}$

Good arguments support the view that the Charter has had a constitutional quality $a b$ initio. In the course of the last fifty years the "constitutional predisposition" of the Charter has been confirmed and strengthened in such a way that today the instrument must be referred to as the constitution of the international community. This characteriza-

1. Philip Allott, Eunomia: New ORder For A NEW WORLd 418 (1990).

2. F.M. van Asbeck, Public International Law in Motion: Farewell Lecture Delivered at Leyden University (1959), in INTERNATIONAL SOCIETY IN SEARCH OF A TRANSNATIONAL LEGAL ORDER 452, 453 (H.F. van Panhuys \& M. van Leeuwen Boomkamp eds., 1976).

3. See Harry S. Truman, Speech (June 26, 1945) in I Documents OF THE UNITED NATIONS CONFERENCE ON INTERNATIONAL ORGANIZATION 680 (United Nations Information Organizations eds., 1945). 
tion goes beyond a now widely-shared perception of the Charter as the "constituent treaty" of an international organization which has to be distinguished from other treaties because it establishes permanent organs and lays down the rules by which they shall function. Rather, I suggest that the Charter is the constitution of the international community in its entirety, i.e., all subjects of international law, and that such an understanding of the Charter has significant repercussions for its legal status, interpretation, amendment, and possible future reform.

First, I will depict how the concept of a constitution has been used with regard to the modern state, which is its historical and theoretical point of departure. Next, I will present writers who-though in very different ways-have made consistent use of "constitutional" arguments in international law and, in particular, with regard to the Charter. I distinguish three main groups of scholars: the school founded by the Viennese jurist Alfred Verdross; the New Haven School; and authors focusing on the idea of an "international community." Based on this analysis, I will explain why the concept of constitution can be applied to bodies other than states, and discuss the relationship between international community and international constitution. In a fourth section, I will discuss a number of characteristic features which, together, represent a paradigm, or, in Max Weber's methodology, Idealtypus of constitution to which the Charter is compared. Subsequently, I will distinguish the constitutional law of the international community from "general international law," jus cogens, and obligations erga omnes. Finally, I will outline a few consequences of the constitutional approach. A question of particular interest is that of admission and expulsion of members.

\section{II. “CONSTITUTION" AND ITS ASSOCIATION WITH THE MODERN STATE}

What is or makes a "constitution"? As is true for many other fundamental notions of law, the term, even if limited to public communities, is used in many different ways. Definitions vary from period to period, place to place, and author to author. Today, positivist ideas compete with those of legal realism and fragments of continental preWorld War II teachings. It seems that continental scholars have been more interested in the abstract question of how to define a constitution than British or American authors. Great Britain does not have a written constitution, and the Americans lived for more than two hundred years under an instrument the constitutional quality of which they have no reason to question. Europeans, on the other hand, have experienced many constitutional breaks and instances of constitution-making since 
the end of the eighteenth century. The pragmatism of common law lawyers, who are less inclined to fall under the spell of abstract notions, may also account for the relative absence of a pertinent Anglo-American debate. The question of how a constitution works is deemed more important than that of what a constitution is.

In Germany and Austria, the years between the two World Wars saw a few scholars whose differing approaches continue to influence constitutional thought in Europe and beyond: Hans Kelsen, Rudolf Smend, Hermann Heller, and Carl Schmitt. Their teachings reveal the variety of ideas, notions and historical experiences associated with the constitutional concept.

In Kelsen's positivist "pure theory of law"-a theory meant to free the law from all purportedly extra-legal elements-a constitution is described as "the highest level within national law." The positive constitution is further classified as a constitution in a formal and in a material sense. ${ }^{4}$

The constitution in the formal sense is a certain solemn document, a set of legal norms that may be changed only under the observation of special prescriptions, the purpose of which it is to render the change of these norms more difficult. The constitution in the material sense consists of those rules which regulate the creation of the general legal norms, in particular the creation of statutes. ...5

Rudolf Smend emphasized the integrative and conciliatory function of constitutional law. "The constitution is the (positive) legal order of a state and, more exactly, the process of its integration." 6

Following Smend and Heller, Konrad Hesse has defined a constitution as the "legal fundamental order of a public community."

[The constitution] determines the guiding principles according to which political unity shall be constituted and governmental tasks be performed. It establishes procedures to

4. See HANS KelSEN, Allgemeine StAATSLEHRE 248-54 (photo. reprint 1993) (1925).

5. Hans Kelsen, General Theory of Law and State 124 (1945). See also Hans KELSEN, REINE RECHTSLEHRE 228-30 (photo. reprint 1983) (2d ed. 1960).

6. RUDOLF SMEND, VERFASSUNG UND VERFASSUNGSRECHT 78 (1928), reprinted in RUDOLF SMEND, STAATSRECHTLICHE ABHANDLUNGEN UND ANDERE AUFSÄTZE 119 (3d ed. 1994). Philip Allott describes the principle of integration as one of seven "generic principles of a constitution." However, to him integration of law means that law is part of the total social process, and not so much that it integrates society. ALLOTT, supra note 1, at 168, 170-71, 29899. On the other hand, a constitution is seen as an essential part of the self-identifying, selfstructuring and self-ordering of society. See ALLOTT, supra note 1, at 141-43.

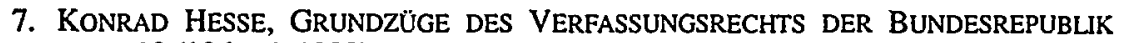
DEUTSCHLAND 10 (19th ed. 1993). 
resolve conflicts in the community, and organizes and structures the formation of political unity and governmental activity. It creates the foundations and sets forth the essential features of the legal order as a whole.

Carl Schmitt established a hierarchy between a "constitution" and constitutional laws, insisting on the relative importance of the latter. The constitution-not being a law or a norm, but a decision-comes first; the constitutional laws follow. A constitution, as the prerequisite of any legislation, including the adoption of constitutional laws, is "the fundamental political decision of the entity in whom the power to establish the constitution is vested."9 From this distinction Schmitt drew several conclusions, in particular with regard to the possibility of amending constitutional law.

Hermann Heller criticized Schmitt's attack on formal constitutional law as incompatible with the idea of rule of law. A constitution, he said, could not be understood as a merely factual "decision" of a nonnormative power. At the same time, he also rejected Kelsen's concept of a constitution the validity of which depends on a "basic norm" constructed by logical inference. ${ }^{10}$

In the United States, the authors of the Federalist Papers underlined the character of the constitution as "higher law" binding the executive, legislative and judicial branches of government. James Madison emphasized the distinction "between a Constitution established by the people and unalterable by the government, and a law established by the government and alterable by the government." "Where no Constitution, paramount to the government, either existed or could be obtained, no constitutional security, similar to that established in the United States, was to be attempted." 11 Alexander Hamilton defined a "limited constitution" as "one which contains certain specified exceptions to the legislative authority," and which provides for a control of this authority by independent courts. "No legislative act, therefore, contrary to the Constitution, can be valid. To deny this would be to affirm that the deputy is greater than his principal; ... that the representatives of the people are superior to the people themselves ...."12

8. Id. For a similar view of the function of a constitutional system, see Marc Weller, The Reality of the Emerging Universal Constitutional Order: Putting the Pieces of the Puzzle Together, 10 CAMBRIDGE REV. INT'L AFF. 40, 43 (Winter-Spring 1997).

9. CARL SCHMITT, VERFASSUNGSLEHRE 23 (1928).

10. See Hermann Heller, StaAtSlehre 264-65, 276-77 (1934).

11. THE Federalist No. 53, at 331-32 (James Madison) (Clinton Rossiter ed., 1961).

12. THE Federaust No. 78, at 466-67 (Alexander Hamilton) (Clinton Rossiter ed., 1961). 
Following those ideas, the U.S. Supreme Court asserted an authority of judicial review as early as in 1803. Chief Justice John Marshall's famous statement in Marbury $v$. Madison characterized the constitution as "a superior, paramount law, unchangeable by ordinary means."13

Although the Framers imagined the Constitution as an authoritative text and the highest form of law, "the legal tradition in which the Constitution came to be immersed refused to share this ideal; here true law-givers were judges, who discovered the true meaning of spoken and written normative sources generated by competing power centers." Case-law, following its own inner dynamics, reduced the significance of the constitutional text, and the view that the Constitution is a charter of principles conflicted with the heritage of judge-made law with its innate skepticism about abstract rules and schemes. ${ }^{14}$ Observing and justifying this development of the Constitution by practical application, American legal realism described "any working constitution ... as being in essence not a document, but a living institution built (historically, genetically) in first instance around a particular document." 15 As far as constitution is understood as a process, this view and Rudolf Smend's coincide. ${ }^{16}$

Influential as this Realist opinion has been, it has never remained unchallenged. In a dissenting opinion of 1966, Justice Hugo Black, for instance, artfully defended positivist thought and criticized the majority "for consulting its own notions rather than following the original meaning of the Constitution." To him, this was "an attack not only on the great value of our Constitution itself, but also on the concept of a written constitution which is to survive through the years as originally written unless changed through the amendment process which the Framers wisely provided." 17 Being interested in American opinions on what makes up a constitution, one thus has primarily to look at the discussion about constitutional interpretation. ${ }^{18}$

13. 5 U.S. (1 Cranch) 137, 2 L. Ed. 60 (1803).

14. Mirjan R. Damaška, Reflections on American Constitutionalism, 38 AM. J. COMP. L. 421, 426-28, 442 (1990).

15. Karl Llewellyn, The Constitution as an Institution, 34 CoLUM. L. REv. 1, 3 (1934).

16. Both doctrines arose at the same time. I do not know whether their possible interaction has already been studied.

17. Harper v. Virginia Board of Elections, 383 U.S. 663, 677-78 (1966) (Black, J., dissenting) (emphasis added).

18. See, e.g., INTERPReting the Constitution: The Debate over Original INTENT (Jack N. Rakove ed., 1990). 
Both positivist and Realist ideas have been integrated by Philip Allott who distinguishes three faces of a constitution-the legal, the real, and the ideal. His views also epitomize the degree to which formerly sharply divided opinions about the nature and role of a constitution have moved closer in our time.

The legal constitution is the constitution as law, a structure and a system of retained acts of will ... which are concerned with the distribution and use of social power .... The legal constitution determines the categories of person holding the categories of social power; it determines the contents and limits of social power. It determines the methods of implementing and enforcing social power....

The real constitution is the constitution as it is actualized in the current social process, a structure and a system of power....

The ideal constitution is the constitution as it presents to society an idea of what society might be . . . . In the ideal constitution, society conceives of its other selves, possible selves which conform to its idea of itself as society .... Its possible selves are possibilities inherent in the legal constitution and the real constitution, but they are also possibilities which shape the legal and the real constitution. ${ }^{19}$

If we turn our attention to the constitutions of states in force, we find that, notwithstanding the different theories summarized above, and notwithstanding special accommodations responding to particular historical or political conditions, constitutions almost always present a complex of fundamental norms governing the organization and performance of governmental functions in a given state ("frame of government") and the relationship between state authorities and citizens. More recently, statements of policy goals (regarding, for example, economic development, culture, international peace, and conservation) feature prominently in constitutional texts. ${ }^{20}$ In principle, the instrument shall provide a legal frame and guiding principles for the political life of a community for an indefinite time. It is (positive) law attributed to the sovereign (in a democratic state the people), binding on all state institutions and in this respect paramount, extending to all members of

19. ALLOT, supra note 1 , at 135-36. See also id. at 255,415 .

20. For a comprehensive comparative analysis of such clauses, see KARL-PETER SOMMERMANN, STAATSZIELE UND STAATSZIELBESTIMMUNGEN (1997). See also LOUIS HENKIN, ELEMENTS OF CONSTITUTIONALISM 1 (Columbia University Center for the Study of Human Rights ed., 1994) (emphasizing the programmatic-i.e., non-normative-character of former socialist constitutions). 
the society and, generally, governing the exercise of all public authority. More often than not, it is arranged in a single written text and more difficult to amend than other law. The idea of constitutional supremacy, i.e., of the constitution taking precedence over law of "lower rank," with the consequent possibility of unconstitutional, and therefore void, legislative acts, was generally accepted only in this century. It gains practical importance if courts (either all of them, or only higher, or special constitutional courts) are empowered to review the constitutionality of such acts.

The American and European "constituted," or "constitutional," state of the nineteenth and twentieth century has given the formal notion of constitution a specific substantial meaning which by now has largely superseded the other denotations. In 1776, the Concord Town Meeting declared that "a Constitution in its proper idea intends a system of principles established to secure the subject in the possession and enjoyment of their rights and privileges, against any encroachments of the governing part." In that same sense Article XVI of the French Déclaration des droits de l'homme et du citoyen of 1789, which was made part of the constitution of 1791, read: "Toute société, dans laquelle la garantie des droits n'est pas assurée ni la séparation des pouvoirs déterminée, n'a point de constitution." Human rights and political freedoms of citizens, sovereignty and self-determination of the people, democracy and separation of powers, rule of law-these partially overlapping terms describe the distinctive content which the notion has acquired. ${ }^{22}$ Accordingly, a constitution is a matter of form and content.

For its implementation and enforcement, constitutional law cannot rely upon any higher law or authority. It is the structure of the constitution itself which has to ensure its effectiveness and duration. ${ }^{23} \mathrm{~A}$ constitution establishes rules regarding the formation and exercise of political power. It is in constant interaction with strong social forces, such as parties, pressure groups, bureaucratic or military institutions, which it cannot completely control. In that sense, its future is precarious. As the German scholar Ulrich Scheuner wrote, "fundamentally, every constitution is a blueprint of a political order with which the present

21. For text, see SOURCES AND DOCUMENTS ILLUSTRATING THE AMERICAN REVOLUTION 1764-1788 AND THE FORMATION OF THE FEDERAL CONSTITUTION 176 (Samuel Eliot Morison ed., 2d ed. 1929). For the importance of the "language of rights" for American constitutionalism, see Gerhard Casper, Changing Concepts of Constitutionalism: 18th to 20th Century, 1989 SUP. CT. REv. 311, 312, 316.

22. See HENKIN, supra note 20 , at $2-8$.

23. See Ulrich Scheuner, Verfassung, in STAATSTHEORIE UND STAATSRECHT: GESAMMELTE SCHRIFTEN 171, 173-74 (Joseph Listl \& Wolfgang Rüfner eds., 1978). 
seeks to bind the future." 24 If the framers are wise, they ordain rules sufficiently open and flexible to evolve together with the community whose life they shall govern.

\section{THE TRANSFER OF THE CONSTITUTIONAL IDEA INTO THE SPHERE OF INTERNATIONAL LAW: DIFFERENT APPROACHES}

Today, the terms "constitution" and "constitutional law" are not infrequently used by judges and scholars with regard to international law and, particularly, the United Nations. However, this rhetoric is rarely based on any coherent idea of constitutionalism. Only few writers have made an effort systematically to explain both the reasons and the consequences of the adoption of constitutional arguments. They can be grouped into three major schools: the one founded by the Viennese jurist Alfred Verdross, the New Haven School, and the doctrine of international community, respectively. In this section, I will first identify typical, unsystematic uses of constitutional language. I will then discuss in more detail the three schools.

\section{A. Unsystematic Ways of Using Constitutional Language}

First, the notion of constitution appears to have been introduced in international law to distinguish treaties establishing an institution (i.e., a legal entity endowed with its own organs) from other international agreements. This is the rather innocent reason for official expressions like "Constitution of the World Health Organization" or "Constitution of the International Labour Organization." Here, "constitution" is a synonym for what Article 5 of the Vienna Convention on the Law of Treaties calls a "constituent instrument." 25 Wolfgang Friedmann referred to "international constitutional law" as the comparative study of "constitutions" of intergovernmental organizations. ${ }^{26}$

But there are more ambitious intentions. President Truman's opinion that some sort of dynamism is inherent in the very concept of a constitution is widely shared. Professor Franck said,

24. Id. at 173.

25. For corresponding academic usage, see, e.g., Henry G. Schermers, International Organizations, in INTERNATIONAL LAW: ACHIEVEMENTS AND PROSPECTS 67, 68 (Mohammed Bedjaoui gen. ed., 1991). (1964).

26. See Wolfgang Friedmann, THE Changing Structure of INTERNATIONAL LAW 153 
[t]he law of, or about, international organizations is essentially constitutional law. This is true not only because it is descriptive of the internal rules governing the operation of institutions and societies, but because it is treated by lawyers in a manner different from other law-treated as being capable of organic growth. ${ }^{27}$

Professor Rosenne has demonstrated that scholars and judges advancing a "constitutionalist" theory conceptually distinguish constituent instruments of intergovernmental organizations from the bulk of multilateral treaties, in particular with regard to their interpretation, the acquisition and loss of membership, reservations, and amendments. ${ }^{28}$ "[T] $]$ he element of treaty appears merely as the presupposition of the organization, the foundation upon which the superstructure, the constitution of the organization, and even more the constitutional practices based on that constitution, are established."29

The International Law Commission referred to the notion of a constitution when seeking to explain that the legal capacity of an intergovernmental organization does not only depend on the terms of its constituent treaty. ${ }^{30}$ With regard to the U.N. Charter, the terms "constitution" and "constitutional" were occasionally invoked by members of the International Court of Justice to support a method of Charter interpretation oriented to pursuing the aims and purposes of the U.N. in a

27. Thomas M. Franck, Book Review, 77 HARV. L. Rev. 1565 (1964) (reviewing D.W. Bowett, The Law of International Institutions (1963)).

28. See ShabTaI RosenNe, DeVElopmentS IN THE LAW OF TREATIES 1945-1986, at 181258 (1989).

29. Id. at 191.

30. Considering Sir Humphrey Waldock's report on the law of treaties, the I.L.C. adopted the following redraft of article 3, paragraph 4, on June 22, 1962: "In the case of international organizations capacity to conclude treaties depends on the constitution of the organization concerned." 1 Y.B. INT'L L. COMM'N 240 (1962) (emphasis added). Sir Waldock explained that the expression "had been chosen because it was broader than 'constituent instrument'; it covered also the rules in force in the organization." Id. at 242. In its commentary, the I.L.C. noted:

The term 'constitution' has been chosen deliberately in preference to 'constituent instrument.' For the treaty-making capacity of an international organization does not depend exclusively on the terms of the constituent instruments of the organization but also on the decisions and rules of its competent organs. ... [1]t is the constitution as a whole-the constituent treaty together with the rules in force in the organization-that determine the capacity of an international organization to conclude treaties.

2 Y.B. INT'L L. COMM'N 164 (1962). The Commission later decided to omit the question of the treaty-making capacity of international organizations from the draft articles. 
changing global context. ${ }^{31}$ As Professor Skubiszewski noticed, "the perception of the Charter as a constitution" with its "emphasis on the purposes of the Organization favours the teleological method and the application of the doctrine of implied powers."32 Similarly, in textbooks of international law, ${ }^{33}$ and even in political discourse,${ }^{34}$ constitutional language is now often used with regard to founding treaties of international organizations and, in particular, the U.N. Charter, but generally no reasons are given for the adoption of this terminology.

The question of interpretation aside, a "constitution" is referred to as a symbol of a higher form of (political) unity in the international sphere. A "draft constitution of a League of Nations" submitted in 1918 by a German politician influenced by President Wilson's ideas was presented with the words that the league should be "a higher community of peoples joining together for the preservation of peace and their

31. For a particularly clear expression of this idea, see Voting Procedures on Questions Relating to Reports and Petitions Concerning the Territory of South-West Africa, 1955 I.C.J. 67, 106 (June 7) (Lauterpacht, J., sep. op.) ("A proper interpretation of a constitutional instrument must take into account not only the formal letter of the original instrument, but also its operation in actual practice and in the light of the revealed tendencies in the life of the Organization."). See also id. at 112 ("constitutional Charter"), and International Status of SouthWest Africa, 1950 I.C.J. 128, 186, 187 (July 11) (de Visscher, J., dissenting) ("a treaty of a constitutional character like the United Nations Charter"). A "broad and liberal interpretation" of Charter provisions commensurate with "the ever changing pattern of international existence" was also advocated by Sir Percy Spender. See Certain Expenses of the United Nations, 1962 I.C.J. 151, 182, 185-87 (July 20) (Spender, J., sep. op.). Judge Alvarez, who perhaps was the strongest advocate of the method of teleological Charter interpretation on the bench, referred to certain categories of multilateral conventions, among them "those which seek to develop world international organization," as "the Constitution of international society, the new international constitutional law," and explained: "They are not established for the benefit of private interests but for that of the general interest; they impose obligations upon States without granting them rights ..... See Reservations to the Convention on the Prevention and Punishment of the Crime of Genocide, 1951 I.C.J. 15, 49, 51 (May 28) (Alvarez, J., dissenting). For comment, see Georg Schwarzenberger, The Problem of International Constitutional Law in International Judicial Perspective, in RECHT IM DIENST DES FRIEDENS: FESTSCHRIFT FÜR EBERHARD MENZEL ZUM 65. GEBURTSTAG AM 21. JANUAR 1976 241, 243-49 (Jost Delbrück et al. eds., 1975).

32. See Krzysztof Skubiszewski, Remarks on the Interpretation of the United Nations Charter, in VÖLKERRECHT ALS RECHTSORDNUNG-INTERNATIONALE GERICHTSBARKEIT -MENSCHENRECHTE: FESTSCHRIFT FÜR HERMANN MOSLER 891, 893 (Rudolf Bernhardt et al. eds., 1983). For characteristic elements of an "interpretative process as applied in a 'constitutionalist' manner," see ROSENNE, supra note 28, at 237-43. 1990).

33. See, e.g., IAN BROWNLIE, PRINCIPLES OF PUblic INTERNATIONAL LAW 689 (4th ed.

34. See, e.g., the statement by United Kingdom Ambassador to the U.N. Ivor Richard, Nov. 12, 1974, quoted in YEHUDA Z. BLUM, ERODING THE UNITED NATIONS CHARTER 7 (1993) ("[T]he Charter is and must be the constitutional foundation for all that we do. Respect for that Charter must permeate all our decisions."). 
common well-being." 35 In this view, a community which can rightly call its fundamental rules a "constitution" has realized a particularly high degree of cohesion.

\section{B. Alfred Verdross and his School}

It is not by chance that the first scholar who established the notion of constitution in the context of international law arose from a school assuming a unity of (national and international) law. This scholar was Alfred Verdross, a student of Hans Kelsen, who, in 1926, published a book entitled Die Verfassung der Völkerrechtsgemeinschaft (The Constitution of the International Legal Community). ${ }^{36}$ In this study, which was based on Kelsen's monism, he used the word to describe "those norms which deal with the structure and subdivision of, and the distribution of spheres of jurisdiction in, a community." ${ }^{37}$ Accordingly, neither Kelsen's Grundnorm nor international law as such was understood to make up this constitution. Rather, this constitution was cromrpised of the fundamental principles of international law determining its sources, subjects and execution, and the jurisdiction allocated to states.

In his long life, Verdross repeatedly addressed the problem of an international constitution and, within a certain spectrum, he arrived at different conclusions. Compared to his monograph of 1926, given in the first postwar edition of his treatise on international law: "Those norms which constitute this community [of international law], can be called a constitution of the community of states in a substantive sense. But as [this notion] is used in a broader or narrower sense, either all or only the most important rules of general international law can be grouped under this heading." ${ }^{\text {"38 }}$ According to the Viennese scholar, the constitution of the universal community of states was based on customary law and some multilateral treaties like the Kellogg-Briand Pact of 1928. Since the establishment of the League and the U.N., the community of states also had a constitutional instrument, that is a constitution in a formal

35. MatThias ERzBerger, DeR VölKerbund: DeR Weg ZUM WeltFRIEDEN 161-62 (1918) (draft constitution at 184-94).

36. For a comprehensive evaluation of Verdross' work, see the articles published in 6 EuR. J. INT'L L. (1995). With regard to our question, see, in particular, Bruno Simma, The Contribution of Alfred Verdross to the Theory of International Law, id. at 33.

37. ALFRED VERDROSS, DIE VERFASSUNG DER VÖLKERRECHTSGEMEINSCHAFT v (1926).

38. ALFRED VERDROSS, VÖLKERRECHT 74 (2d ed. 1950). 
sense. This constitution, however, was only "quasi-universal" and existed only in the framework of general international law. ${ }^{39}$

In 1976, Verdross, in a new edition of his treatise coauthored with Bruno Simma, claimed that today the constitutional law of the universal community is embedded in the United Nations Charter. ${ }^{40}$ In the past, one had had to distinguish between general international law and the law of the U.N., the latter only applying to a part of the community of states.

But since the U.N. includes almost all states and the few states which remain outside have recognized its fundamental principles, the U.N. Charter has gained the rank of the constitution of the universal community of states. Therefore, we had to take the Charter as a starting point and explain the law which had been in force before the Charter became operative in the framework established by the latter because that [earlier] law is now binding only in so far as it has not been repealed by the Charter .... $4 \mathrm{I}$

Verdross and Simma use the term "constitution" in a normative sense. It is a set of rules of international law which take precedence over other norms in so far as their existence is a precondition for the validity of the latter from a logical and a legal point of view. At the same time, constitution is regarded as an outcome of history or, in other words, a result of an actual agreement among states at a particular point of time rather than a purely theoretical construct. In the development of modern international law, this constitution has become ever more comprehensive, with regard to its geographical sphere of operation as well as the complexity of its rules. Starting with a few limited principles, mainly concerning the creation of international law, this constitution now encompasses far-reaching substantive rules with which all states have to comply. The founding document of the U.N. replaced the constitutions of the non-organized community of states when the U.N. gained universal acceptance. For the first time, a written text became the constitution of the world community.

39. See id. In the fifth edition of his treatise, Verdross returned to a stricter definition. See VERDROSS, VöLKERRECHT 136 (in collaboration with Stephan Verosta \& Karl Zemanek, 5th ed. 1964).

40. See ALFRED VERDROSS \& BRUNO SMMA, UNIVERSELLS VÖLKERRECHT: THEORIE UND PRAXIS 5 (1976).

41. AlFrEd VERdROSS \& BRUNO SimMA, UNIVERSELLES VÖLKERRECHT: THEORIE UND PRAXIS vii-viii (3d ed. 1984) (emphasis added) [hereinafter VERDROSS \& SIMMA (3d ed.)]. See also id. at 72,221. Albert Bleckman supports the theory that general international law has been incorporated by the Charter. See Albert Bleckmann, Comment on Art. 2(1), in THE CHARTER OF THE UNITED NATIONS: A COMMENTARY 77, 79 (Bruno Simma ed., 1994) [hereinafter CHARTER OF THE U.N.]. 
Steadily gaining ground, in particular among German and Austrian scholars, ${ }^{42}$ this notion of constitution of the universal community of states oscillates between on the one hand, general principles of law common to states, enabling them to enter into legal relations and build a legal community, and on the other hand, a more comprehensive system of fundamental rules the nature of which can again be either formal or substantive.

Professors Verdross and Simma, however, shy away from drawing those conclusions from their approach which alone appear to be logical. Take, for instance, the question of amendments to the Charter. In 1973, Verdross said that the Charter, "because it was established on the basis of the constitution of the international legal community," cannot only be amended according to its articles 108 and 109 but also in every other way provided for by that constitution, that is by any kind of international agreement or rule of customary law. ${ }^{43}$ But if the Charter is now understood as "a part" of that very constitution, ${ }^{44}$ so that the instrument and its "legal basis" have merged and the Charter has risen to the constitutional level, there is no longer any higher category of law which would take precedence over the express rules of the Charter. The problem of the relationship between the Charter and "general international law" is even more striking in Verdross' and Simma's treatise. Here, the Charter "is an international treaty which can be amended according to the generally applicable rules." ${ }^{45}$ Is it possible, or helpful, to call a set of rules applying to a legal community its "constitution" if these rules are governed by yet another set of rules? At the same time, the Charter, as the constitution of the international community, is said to have incorporated "general international law." Do then the "generally applicable rules" exist on the same (constitutional) plane as the norms of the Charter proper? If this is true, it remains unclear which rules of

42. See Heribert Franz Köck, UN-Satzung und allgemeines Völkerrecht: Zum exemplarischen Charakter von Art. 103 SVN, in VÖLKERRECHT ZWISCHEN NORMATIVEM ANSPRUCH UND POLITISCHER REALITÄT: FESTSCHRIFT FÜR KARL ZEMANEK ZUM 65. GEBURTSTAG 69, 88-89 (Konrad Ginther et al. eds., 1994); Jochen A. Frowein, Reactions by Not Directly Affected States to Breaches of Public International Law, 248 REC. DES COURS 349, 356-62 (1994-IV); Georg Ress, Interpretation, in THE CHARTER OF THE U.N., supra note 41, at 27,42. Louis Henkin refers to the Charter as "a new social contract [of the international system]." Louis Henkin, The Mythology of Sovereignty, in ESSAYS IN HONOUR OF WANG TIEYA 351 , at 357 (R. St. J. Macdonald ed., 1993). See also Rudolf Bermhardt, Comment on Art. 103, in THE CHARTER OF THE U.N., supra note 41, at 1119,1123, 1125; and Wolfgang Graf Vitzthum, Comment on Art. 2(6), in id. at 138.

43. ALFRED VERDROSS, DIE QUELLEN DES UNIVERSELleN VölKERRECHTS: ENNE EINFÜHRUNG 35-36 (1973).

44. Id. at 35 .

45. VERDROSS \& SimMA (3d ed.), supra note 41, at 168. 
general international law the Charter has incorporated with the consequence that they share its constitutional quality. ${ }^{46}$ It seems that two fundamentally different views have not been reconciled-the traditional perception of the Charter as a treaty which is governed by the rules of general international law, and the novel constitutional approach, which finds it difficult to make the validity of the instrument depend on norms outside the Charter.

\section{The New Haven School}

Confronting the analytical tradition and its preoccupation with rules, and further developing earlier sociological approaches to law, the New Haven School of Jurisprudence is "emphatically oriented to process and context."47 A reader not familiar with the school's general ideas has to be careful not to misread terms like "constitutional" and "constitutive" which have a meaning distinctly different from that prevailing in mainstream legal writing.

A key term of the School is that of "constitutive process." This process is described as "authoritative power exercised to provide an institutional framework for decision and to allocate indispensable functions"; its outcome-"constitutive decisions"-are those decisions

which identify and characterize the different authoritative decision-makers in a community, specify and clarify basic community policies, establish appropriate structures of authority, allocate bases of power for decision and sanctioning purposes, authorize procedures for making the different kinds of decisions, and secure the continuous performance of all the different kinds of decision functions (intelligence, promotion, prescription, etc.) necessary to making and administering general community policy. ${ }^{49}$

46. The conflict between progressiveness and traditionalism, which is characteristic of the doctrine, appears from a recent comment by Professor Simma. See Bruno Simma, Human Rights, in THE UNITED NATIONS AT AGE FIFTY: A LEGAL PERSPECTIVE 263, 270 (Christian Tomuschat ed., 1995). (1994).

47. Nicholas Onuf, The Constitution of International Society, 5 EUR. J. INT'L L. 1, 5

48. Myres S. McDougal et al., The World Constitutive Process of Authoritative Decision, in MYRES S. MCDOUGAL \& W. MICHAEL REISMAN, INTERNATIONAL LAW ESSAYS: A SUPPLEMENT TO INTERNATIONAL LAW IN CONTEMPORARY PERSPECTIVE 191, 192 (1981).

49. HaRold D. LASSWEll \& MYRES S. MCDOUGAL, I JURISPRUdenCE FOR A FREE SOCIETY: STUDIES IN LAW, SCIENCE AND POLICY 93 (1992). 
Seen in the light of this theory, the Charter represents a constitutive decision. In particular, it identifies authoritative decision-makers and procedures for decision-making. At the same time, further constitutive decisions can originate in the organization. Think, for example, of the Security Council entrusting a sub-body with making certain decisions.

Charter-based procedures are seen as a part of a "network of practices specialized to decision"; ${ }^{50}$ the Charter "is only a part of [the] ongoing world constitutive process." "51 The New Haven School is concerned with the "description and appraisal of the whole factual constitutive process" rather than with a "description of a number of formal governmental structures." 52 Seeing law from the "policy perspective," the School insists that the "changing features of "world constitutional law' are to be understood by perceiving the intimacy of interplay between law and the entire social process of the world community." 53

From this it follows that the New Haven School cannot support the idea of the U.N. Charter as a constitution in a normative sense, i.e. as written constitution of the international community. The School is not concerned about a weakening of state freedom caused by an expansion of the scope of obligations arising for states. It must reject international constitutional law so understood as an antiquated revival of normativism or inadequate "conventional constitutionalism." ${ }^{\text {"I }}$ In the School's view, the U.N. Charter is an expression of "constitutive decisions" establishing a process of authoritative decision. However, as was already pointed out, the process of writing a "constitution" is seen as just the beginning of a continuing "constitutive process."

The problem with this approach is that law as it appears "in the books" is easily called into question while only skilled observers are able to determine in an ambitious exercise the "new" law supposed to be applicable at a given moment of time. The outcome of this operation is, of course, again open to criticism. Influenced by the realist movement's critique of textualism, the School has pushed the inductive method in international law to its limits. ${ }^{55}$

50. McDougal et al., supra note 48, at 194.

51. W. Michael Reisman, The Constitutional Crisis in the United Nations, 87 AM. J. INT'L L. 83, 100 (1993).

52. McDougal et al., supra note 48 , at 198-99.

53. Id. at 195.

54. See McDougal et al., supra note 48 , at 226.

55. See also, e.g., MARTI KOSKENNIEMI, FrOM APOLOGY TO UTOPIA: THE STRUCTURE OF INTERNATIONAL LEGAL ARGUMENT 170, 176 (1989). 
However, a constitution shall authoritatively, and as clearly as possible, inform all members of a legal community of their rights and responsibilities, the institutions set up by the constitution, and their powers and procedures. Every member of the group shall be able to rely on the wording of the constitution as long as it has not been amended in the way provided for in the instrument itself. "[A] constitution can be a fundamental order existing as a matter of fact. But with respect to its contents, general validity and duration it only becomes reliable if it has been put into legal terms and given the form of a written instrument." It is this unambiguous legal foundation which the international community would win by recognizing the Charter of the United Nations as its constitution. Constitutional interpretation provides for the necessary adjustment to new circumstances. "A difficult balance must thus be found between maintaining, on the one hand, the sanctity of the constitution and the concept of the rule of law, and, on the other, ensuring through imaginative interpretation the survival of the organization in the stress and strain of modern civilization." 57

\section{The Doctrine of International Community}

Against the background of traditional international law, Professor Verdross' concept was a bold and revolutionary one, and the New Haven School developed a new and distinctive approach which stressed the interdependence of law and politics. The ideas first advanced by the late Judge of the International Court of Justice Hermann Mosler represent a cautious, but nevertheless consequential transition from traditional doctrine to a more progressive theory. In his lectures delivered in the Hague in 1974, he sought to depict "the international society as a legal community"58 - that is, "to show how the international society, consisting of States and organisations set up by States,

56. Paul Kirchhof, Die Identität der Verfassung in ihren unabänderlichen Inhalten, in I HANDBUCH DES STAATSRECHTS DER BUNDESREPUBLIK DEUTSCHLAND 775, 776 (Josef Isensee \& Paul Kirchhof eds., 1987) [hereinafter HANDBUCH DES STAATSRECHTS]. For a theoretical and historical inquiry into the foundations of, and reasons for, a written constitutional instrument, see Hasso Hofmann, Zur Idee des Staatsgrundgesetzes, in RECHT-POLITIK-VERFASSUNG: STUDIEN ZUR GESCHICHTE DER POLITISCHEN PHILOSOPHIE 261 (1986); and Dieter Grimm, Der Verfassungsbegriff in historischer Perspektive, in DIE ZUKUNFT DER VERFASSUNG 101, 126-28 (1991) [hereinafter ZUKUNFT]. See also ALLOTT, supra note 1, at 291 (arguing that the adoption of written constitutions is a necessary concomitant of the self-creating of new societies).

57. Louis B. Sohn, Expulsion or Forced Withdrawal from an International Organization, 77 HARV. L. REV. 1381, 1423 (1964).

58. 140 REC. DES COURS (1974-IV). Revised version published as MOSLER, THE INTERNATIONAL SOCIETY AS A LEGAL COMMUNITY (1980). See also Hermann Mosler, International Legal Community, II ENCYCL. PUB. INT'L L. 1251 (1995). 
constitutes a community governed by law."59 Judge Mosler's remarks emphasize the formal side of a constitution, that part concerned with the creation, validity and termination of law. ${ }^{60}$ Constitution appears to be another word for Kelsen's Grundnorm, the basic norm of a system of positive law upon which the validity of all other norms depends. It provides the ultimate basis of obligation in a legal system. As we have seen, this doctrine also plays a role in the theories set forth by Professors Verdross and Simma. Substantive principles-basic legal values and goals-do not seem to belong to such a constitution, at least not to its core. They are instead said to form the "common public order (ordre public international)." ${ }^{61}$ Mosler assumed "a close connection between jus cogens and public order of the international community," but insisted that the two are not identical. ${ }^{62}$ The latter concept is understood to have a wider meaning because the rules belonging to it "apply not only to the members of the international community acting as contracting parties but are also binding in relevant legal situations other than treaty relations." ${ }^{63}$ In Mosler's view, the I.C.J. adopted the same position in the Barcelona Traction case when it developed the doctrine of obligations erga omnes. These obligations essentially constitute Mosler's "public order." 64

What is the position of the U.N. and its Charter in this constitutional framework? In outright opposition to the view held by Professors Verdross and Simma, Judge Mosler said that "the Charter of the United Nations is not part of general international law, though it may in the course of time come to be generally accepted as such. . . "65 Accordingly, the author is of the opinion that the general principle that a treaty cannot bind a non-member state without its consent also applies to the Charter. ${ }^{66}$ It comes as a surprise, therefore, when the author concludes: "Nevertheless, if there is a real threat to international peace and security in which non-members of the Organisation are involved, intervention by the United Nations is, in my opinion, justified." ${ }^{\text {"W }}$ Why? Nothing in the

59. MOSLER, supra note 58 , at $\mathrm{xv.}$

60. See id. at $15-16,84-85$.

61. See id. at 17.

62. Id. at 19; also quoted in Hermann Mosler, lus Cogens im Völkerrecht, 25 SCHWEIZERISCHES JAHRBUCH FÜR INTERNATIONALES RECHT (ANNUAIRE SUISSE DE DROIT INTERNATIONAL) 9, 22-26 (1968). See also Sir Humphrey Waldock, Second Report on the Law of Treaties, 2 Y.B. INT'LL. COMM'N 36, 52 (1963).

63. MOSLER, supra note 58, at 19.

64. See id.

65. Id. at 192.

66. See id.

67. Id. at 193. 
author's foregoing explanations prepares the reader for such a result. The only possible road connecting the Charter to his principles of a "public order of the international community" binding upon all its members is deliberately not chosen.

Almost twenty years later, the theme of international community was taken up by Professor Tomuschat in his 1993 lectures in the Hague. Much more resolved than his predecessor, he expanded the concept of an international constitution interdependent of the international community.

Together with the rules on discharge of the executive and the judicial functions, the rules on law-making form the constitution of any system of governance. All these sets of prescriptions can be logically characterized as meta-rules, rules on how the bulk of other rules are produced, how they enter into force, how they are implemented and who, in case of differences over their interpretation and application, is empowered to settle an ensuing dispute....

Every modern system of governance is operated through law-making, administration and adjudication. The question arises whether the international community can be called a system of governance regulated by a constitution in the sense just delineated ${ }^{68}$

The author answers this question in the affirmative: "[T]he international community can indeed be conceived of as a legal entity, governed by a constitution. ..." ${ }^{\prime 99}$ Much like the authors examined above, he sees formal rules concerning the creation, implementation and adjudication of law as the key elements of a constitution, Professor Tomuschat subsequently puts more emphasis on substantive provisions, thus joining together what Judge Mosler called "constitution" and "public order:"

The international community and its constitution were created by States. Over centuries up to the present time, buttressed in particular by the U.N. Charter, the idea of $a$ legal framework determining certain common values as the

68. Christian Tomuschat, Obligations Arising for States Without or Against Their Will, 241 REC. DES COURS 195, 216 (1993-IV). See also G.M. DANILENKO, LAW-MAKING IN THE INTERNATIONAL COMMUNITY 14 (1993).

69. Tomuschat, supra note 68 , at 236 . 
guiding principles States are bound to observe and respect has gained ground and has been progressively strengthened. ${ }^{70}$

States live, as from their birth, within a legal framework of a limited number of basic rules which determines their basic rights and obligations with or without their will, leaving them, however, sufficient room for self-responsible action within the openings of that legal edifice. One may call this framework, from which every State receives its legal entitlement to be respected as a sovereign entity, the constitution of international society or, preferably, the constitution of the international community, community being a term suitable to indicate a closer union than between members of a society. ${ }^{71}$

From this it appears that the principal feature of the international constitution is its non-consensual character. A constitution is the entirety of those basic rules-whether procedural or substantive-which every state is bound to observe irrespective of its own will. This marks a departure from the position of Judge Mosler to whom consensus, as principal rules governing the formation and evolution of law, still represents the community's basic constitutional principle. ${ }^{72}$ Among those basic rules, sovereign equality of states is described as "the most basic axiomatic premise of the international legal order" "; it "is the core element of the constitutional framework which no State, acting individually, can reject."74

In another difference with Judge Mosler, Professor Tomuschat brings the Charter in direct relationship with the constitution of the

70. Id. at 236 (emphasis added). See also id. at 314; Christian Tomuschat, Die internationale Gemeinschaft, 33 ARCHIV DES VöLKERRECHTS 1, 7 (1995).

71. Tomuschat, supra note 68 , at 211 (emphasis added). This substantive notion of a constitution of the international society is reminiscent of that put forward by Professor Scelle. "[L]es normes constitutives ou constitutionelles ... sont reconnues à un moment donné, dans une société déterminée, comme étant les bases de toutes les autres prescriptions normatives et constructives, parce qu'essentielles à la vie même et au progrès de la société . . . . Toute collectivité intersociale, y compris la communauté universelle du Droit des Gens repose, comme les collectivités mieux intégrées et notamment les collectivités étatiques, sur un ensemble de règles constitutives essentielles à leur existence, à leur durée, à leur progrès . . . [-] une constitution au sens large, mais au sens juridique ...." GEORGES SCELLE, 2 PRÉCIS DE DROIT DES GENS: PRINCIPES ET SYSTÉMATIQUE 4, 7 (1934). It is characteristic of the change which in recent years has taken place in the jurisprudence of the former socialist countries that the Russian member of the I.L.C. essentially follows Tomuschat's teachings. See Igor Ivanovich Lukashuk, The Law of the International Community, in INTERNATIONAL LAW ON THE EVE OF THE TWENTY-FIRST CENTURY: VIEWS FROM THE INTERNATIONAL LAW COMMISSION 51 (United Nations ed., 1997).

72. See Mosler, supra note 58 , at $1252,1254$.

73. Tomuschat, supra note 68 , at 237.

74. Id. at 292-93. 
international community. The two are not, however, identical (as is the case according to Verdross and Simma). The Charter is styled a "world order treaty," i.e. a treaty "intended to concretize, and elaborate on, principles which on their part are constituent elements of the international legal order."75

Together with rules included in other "world order treaties"-such as the two International Covenants on Human Rights of 1966, the Genocide Convention, the Vienna Convention on Diplomatic Relations and the Law of the Sea Convention-certain provisions of the Charter are hence mirroring and concretizing "the constitutional premises of the existing international legal order."76 The premises themselves are considered to be "unwritten law."77

Professor Tomuschat understands these constitutional rules as part of customary law. What, then, distinguishes them from this latter category? Clearly, they are particularly firm and stable. They have to be kept apart from "contingent prescriptions that, in the same way as traffic rules on left-hand or right-hand driving, must be determined for the sake of legal clarity and avoiding disorder." 78 In the case of contingent rules, state consent can still be regarded as the relevant basis of obligation, whereas constitutional prescriptions are determined by community interests which may allow for some degree of majoritarianism.

Compared to Professors Verdross and Simma, who recognized the U.N. Charter as the constitution of the international community, both the New Haven School and Professor Tomuschat de-emphasize the importance of the instrument. To the former, the Charter is just one, albeit momentous, element in a "world constitutive process of authoritative decision." To the latter, it is but one of several "world order treaties" the provisions of which enjoy constitutional rank to the extent that they relate to "the three basic functions of governance," or mirror and concretize constitutional, or axiomatic, premises of the international legal order. Consequently, the United Nations is not recognized as "a comprehensive organizational structure" of the international community. ${ }^{79}$ The one decisive premise appears to be the sovereign equality of

75. Id. at 269.

76. Tomuschat, supra note 68 , at 299 . Judge Lachs similarly stressed the "constitutional" significance of instruments other but the U.N. Charter. He, however, rather thought of treaties establishing U.N. specialized agencies. See Manfred Lachs, Quelques réflexions sur la communauté internationale, in LE DROIT INTERNATIONAL AU SERVICE DE LA PADX, DE LA JUSTICE ET DU DÉVELOPPEMENT: MÉLANGES MICHEL VIRALLY 349, 354 (1991).

77. See Tomuschat, supra note 68 , at 309.

78. Id. at 286.

79. Id. at 239. 
states, because all the other basic rules to which the author refers either derive from sovereign equality or are expressly stated in the Charter. Since sovereign equality also appears in the text of the Charter, it is not quite clear why it is necessary to go back to "premises" existing independently of the instrument. None of the premises adds anything to what is expressly provided for in the Charter. However, a logical inference from this is that the Charter has to be in accordance with the constitutional premises, and that the power of states to amend it is correspondingly limited. Sometimes the author uses the notion of a constitution only with regard to the constitutional premises or ground rules; then again, the term the term describes all customary and contractual rules concerning the performance of governmental functions in the international community, and concretizing the ground rules.

\section{THE INTERNATIONAL COMMUNITY AND ITS CONSTITUTION}

The foregoing overview of different approaches to the idea of constitutional law of the international community has demonstrated a certain amount of agreement but also considerable differences of opinion. Surrounded by writers standing in the tradition of analytical positivism, the New Haven School has remained alone in twentieth century international legal theory. With its emphasis on legal decisionmaking as part of a larger and complex societal process, and with its caveat that one should not mistake formal rules as the law in force, the School has deeply influenced legal thought. It has contributed to a general awareness of the limited significance of rules, but it has not succeeded in winning the majority over to its edifice of ideas-the theoretical foundations from which this limited significance follows. "Mainstream" legal thought has remained rule-oriented, and ruleoriented is at the heart of the present debate about international constitutionalism. The existence or non-existence of a constitution of the international community with its possible consequences can only be a concern of those who believe in the importance of norms. One must not, however, lose sight of either the process which a constitution represents and of which it is a part, or its task of integrating the respective community.

The present-day debate is dominated by scholars who cautiously seek to develop the international legal system towards greater cohesion and effectiveness. Rooted in positivism and determined not to lose touch with actual state practice, they have difficulty describing as law in force what they have come to believe the law should be. They are hindered from coming up with something like Kelsen's pure science of 
law on the one hand or a coherent and sufficiently differentiated, but anti-normative theory of law as McDougal's on the other. Hence, one finds, a certain improvisation that cannot satisfy those looking for a clear and convincing theoretical foundation upon which the concept of an international constitution could rest. To their most outspoken critics, the schools in the mainstream are unfortunate captives of the old order. ${ }^{80}$ Also, they make little use of earlier theoretical work in sociological jurisprudence and international relations that could help clarify concepts like law, community, and constitution. Taking up a criticism voiced many years ago, one may say that conclusions are based on common sense, opinion, and intuition rather than on theoretical clarification and empirical validation. ${ }^{81}$

The discussion today suffers generally from terminological confusion. While today there is an established use of the word "constitution" with regard to states, nothing like this can be said for the sphere of international law and organization. Here, "constitution" has yet to become a defined category. This is not surprising if one remembers the long and winding road the notion has traveled. To carry a concept that has been shaped in a particular field and historical context into another is always difficult. It is a task especially hard to accomplish in the case of a term that is of central importance to the whole idea of the modern state and, with it, the modern international system.

Those who oppose the relevance of constitutionalism to international law correctly note that the concept is meant to describe or promote a legal integration of states which is more intense than the traditional one. He who is satisfied with the present state of affairs or who insists on preserving the independence of the individual state vis-àvis the international community as much as possible certainly has no reason to refer to the notion of a universal constitution. International constitutionalism is a progressive movement which aims at fostering international cooperation by consolidating the substantive legal ties between states as well as the organizational structures built in the past. The idea of a constitution is summoned as a symbol of (political) unity which eventually will be realized on a global scale.

80. See ALLOTT, supra note 1 , at 296.

81. See Helga Maria Hemes, Concepts of Community in Modem Theories of International Law 485, at 499 (1970) (unpublished Ph.D. dissertation, The John Hopkins University, Baltimore, Maryland) (on file with author). 


\section{A. A Contested Notion}

There are, I think, two major arguments with which one could challenge the adoption of the constitutional idea by international law.

First, one could question whether it is worthwhile trying to make use of a notion which is already marked by certain signs of exhaustion in its traditional domain, the national state. "Constitution" as we understand it today is a concept invented by eighteenth and nineteenth century legal philosophy, one adopted and modified by politics, as an answer to particular problems and aspirations of that age of transition from feudalism to liberalism. Written constitutions were favored as a means of limiting state intrusion on private rights and liberties and of ensuring political participation and self-determination of citizens. Indeed, they served the regulatory needs of that time. When, later, the state was not only supposed to protect citizens against each other and governmental despotism but was also supposed to guarantee minimum standards of social security, the constitution turned out to be a less able tool. ${ }^{82}$ Today, it appears that the new challenges societies are facing, particularly risks arising from scientific and technological progress, can hardly be adequately dealt with by constitutional legislation. Also, new actors like political parties, pressure groups, and domestic, foreign and multinational corporations do not fit in the established constitutional scheme.

Although constitutionalism is not uncontested on a domestic level, the concept still has much to offer scholars of international law. Here, its primary purpose - the organization and allocation of authority and responsibility with the aim of establishing and preserving peace and legal order-is still of topical interest. Classical goals of constitutionalism, such as security and freedom of the individual member of the community, transparency and unambiguousness of the law, separation of powers, law-making procedures adequate to the needs of the community, and peaceful settlement of disputes are yet to be achieved on the international plane. In addition, the notion of the constitution offers a coherent explanation of current developments in international law which more and more emphasize interests of "the international community as a whole" over those of individual states.

The second objection relates to the fact that the present concept of constitution is grounded in Western legal and political thought. At least, discussion has for centuries focused so much on Western texts, from

82. For this and the following, see Dieter Grimm, Die Zukunft der Verfassung, in ZUKUNFT, supra note 56 , at $397-437$. 
Aristotle to Kelsen, that almost no attention has been paid to the possible existence of constitutional thought in other cultures. However, the universal recognition of fundamental human rights, including the dignity of the individual human being (which is a cornerstone of constitutionalism) as well as an increasingly widespread declaration of belief in democracy, points to a stock of common constitutional values that is more substantial than usually is believed. Particular contributions non-Western cultures have made to postwar international law also fit well in the program associated with constitutionalism. These include the promotion of social, economic and cultural rights, the fight against colonialism and racism, and the concept of "common heritage of mankind."

Further, with the achievement of independent statehood in Latin America, Africa, Asia, and the former Soviet Union, the idea of constitution has spread far beyond its Western roots. According to Professor Häberle, there is today an "international family" of constitutional states, a universal community in which there is a free exchange and interplay of ideas and rules. ${ }^{83}$ The drafting of a new constitution in post-apartheid South Africa, in which society at large widely participated, demonstrates a profound belief in a constitution as an instrument of organizing government and securing freedom for individuals and communities. ${ }^{84}$ "This constitution," President Nelson Mandela said, "is our own humble contribution to democracy and the culture of human rights world-wide; and it is our pledge to humanity that nothing will steer us from this cause." ${ }^{\prime 85}$ Deputy President Thabo Mbeki emphasized the African character of the constitution in its universal setting:

As an African, this [constitution] is an achievement of which I am proud, proud without reservation .... . Our sense of elevation at this moment also derives from the fact that this magnificent product is the unique creation of African hands and African minds. But it also constitutes a tribute to our loss of vanity that we could, despite the temptation to treat ourselves as an exceptional fragment of humanity, draw on

83. See Peter Häberle, Die Entwicklungsstufe des heutigen Verfassungsstaates, in RECHTSVERGLEICHUNG IM KRAFTFELD DES VERFASSUNGSSTAATES 105, 107 (1992) [hereinafter RECHTSVERGLEICHUNG]. For a comparative analysis of the constitutional law of developing states, see Häberle, Die Entwicklungsländer im Prozess der Textstufendifferenzierung des Verfassungsstaates, in id. at 791, 820 et seq.

84. See South African Constitutional Assembly, Annual Reports 1995 and 1996 (visited Feb. 23, 1998) <http://www.constitution.org.za/annual.html >.

85. Address by President Nelson Mandela to the Constitutional Assembly on the Occasion of the Adoption of the New Constitution, May 8, 1996 (visited Feb. 23, 1998) <http://www.constitution.org.za/speeches.html>. 
the accumulated experience and wisdom of all humankind, to define for ourselves what we want to be. ${ }^{86}$

In South Africa, the idea of constitution appears to have transcended its Western origins and meaning. This is not to say that elsewhere the very core of constitutionalism is not defied. Islam, for example, rejects a separation of religion and state and, hence, rejects a secular state guaranteeing impartial government, an independent judiciary, and individual freedom of conscience and expression. But in holding these beliefs, Islam seems to be ever more isolated. It can no longer identify "the West" as its rival culture. In fact, basic constitutional concepts and values have come to be almost universally accepted.

In this situation, a constitution of the international community stands a good chance of succeeding, especially as it does not even aim at imposing a specific form of government on nations. All it strives for is the establishment and preservation of an international order in which basic rights and interests of individuals and communities are acknowledged and conflicting claims peacefully settled. Given the diversity of our world, such order can only be based on a framework which we have come to label constitutional.

\section{B. The Traditional Dichotomy Between "The International" and "The Constitutional"}

With the notion of a constitution, the proponents of international community seize one of the central concepts of the modern state, turning a word used to defend national independence into their own weapon. This is not an easy undertaking because, since the time of the American and French Revolution, the two concepts of state and constitution have been so closely linked that one could almost say: Wherever there is a state, there is a constitution, and wherever there is a constitution, there is a state (and no more international law). Since the nineteenth century most scholars assumed as a premise the basic dichotomy between the forum internum of a state, where a sovereign power is entitled and able to make law binding on all its subjects, and the realm of international law which was a system of coordination between equals. The corre-

86. Statement of Deputy President Thabo Mbeki on Behalf of the African National Congress on the Occasion of the Adoption by the Constitutional Assembly of "The Republic of South Africa Constitution Bill 1996," May 8, 1996 (visited Feb. 23, 1998) <http://www.constitution.org.za/speeches.html>. 
sponding legal instruments seemed to be a constitution and statutes on the one hand, and international agreements on the other. ${ }^{87}$

However, there is no compelling reason to reserve the term constitution for the supreme law of a (sovereign) state. This statist constitutionalism, according to which one group of people can live under just one constitution, corresponds to a scheme of disconnected, legally self-sufficient states which is not only refuted by the real world we live in but also explicitly rejected by the many constitutions providing for the possibility of supranational integration. In contrast, Konrad Hesse explicitly defines a constitution as the fundamental legal order of a public community (Gemeinwesen). ${ }^{88}$ The Swiss professor Jean-François Aubert explained that it is the primary object of a constitution to organize a body politic (corps politique). ${ }^{89}$ The Oxford Companion to Law describes a constitution as "[t]he fundamental political and legal structure of government of a distinct political community." Although it is not a legal authority, it may be useful to quote the definition of the word "constitution" from The Oxford English Dictionary: "The system or body of fundamental principles according to which a nation, state, or body politic is constituted and governed."91

87. For a classical German voice, see PAUL LABAND, 1DAS STAATSRECHT DES DEUTSCHEN REICHES 33-34, 55-58 (5th ed. 1911). This concept was an important element of the distinction between Bundesstaat (federal state) and Staatenbund (confederation of states) with which German constitutional lawyers were preoccupied for a good part of the second half of the nineteenth century. See, e.g., GEORG JELIINEK, ALLGEMEINE STAATSLEHRE 774 (3d ed. 1913).

The Maastricht decision of the German Constitutional Court of 1993 still follows this line of thinking. See Brunner v. Federal Government, Entscheidungen des Bundesverfassungsgerichts in Zivilsachen [BHGZ][Supreme Court] 89, 155, 186, 190 (F.R.G.) (1993); unofficial transl. in 69 CoMMON MKT. L. REV. 57, 88, 91 (1994) and 33 I.L.M. 395, 421, 424-25 (1994). See also Josef Isensee, Integrationsziel Europastaat? in 1 FESTSCHRIFT FÜR ULRICH EVERLING 567, 580-81 (Ole Due et al. eds., 1995): "Different from a state, the European Union does not need a constitution .... It is a product of treaty law and viable only due to treaties .... The EU is not able to bring forth a constitution of the quality which is characteristic of the German Basic Law. It is based on individual sovereign states who have joined together in the Union but not on a single sovereign people who would be the source of legitimacy and point of reference of a constitution."

For a recent critical examination of the dichotomy between "the international" and "the constitutional" with regard to the European Union, see J.H.H. Weiler \& Ulrich R. Haltern, The Autonomy of the Community Legal Order-Through the Looking Glass, 37 HARV. INT'L L.J. 411, 417-23 (1996).

88. See HESSE, supra note 7, at 10, and Hesse, Verfassung und Verfassungsrecht, in 1 HANDBUCH DES VERFASSUNGSRECHTS DER BUNDESREPUBLIK DEUTSCHLAND 3, 7 (Ernst Benda et al. eds., 2d ed. 1994).

89. See JEAN-François AUbERT, LA CONSTITUtion, SON CONTENU, SON USAGE 28 (1991).

90. DAVID M. WALKER, THE OXFORD COMPANION TO LAW 277 (1980).

91. 3 THE OXFORD ENGLISH DICTIONARY 790 (2d ed. 1989). 
Peter Häberle's concept of a constitution as a public and open process ${ }^{92}$ is likewise applicable to communities other than a state: "Constitution does not just amount to the constitution of a state." 93 To Philip Allott, "[a] constitution is a structure-system which is shared by all societies." Of the authors of the Weimar period whose works we have considered above, it is Rudolf Smend's idea of a constitution as the legal order of a process of integration that seems particularly suitable for non-statal communities. ${ }^{95}$

The modern state, it is true, deprived legal communities "below" the level of central government of their right of independent lawmaking. The law enacted by them became derivative in the sense that its validity depended on its being in accord with the rules set out by the "highest" authority in "the constitution." However, already the example of a federal state like the United States of America, Germany or the Swiss Confederation, where the individual states retained their constitutions, challenges this clear-cut model.

Today, there is an increasing awareness of the limits of the nationstate in the face of the tasks it is meant to fulfill. It is widely acknowledged that local and regional communities need to be given more responsibility and legal autonomy to perform the tasks central governments are unable adequately to perform. Accordingly, traditionally centralized states like Italy and Spain have established regions and autonomous communities, respectively, with far-reaching legislative and executive powers. ${ }^{96}$ Stemming from neo-Scholastic philosophy, the principle of "subsidiarity" offers a theoretical foundation for the demand for greater local participation, and it has been explicitly recognized in article $3 \mathrm{~b}$ of the E.C. Treaty as inserted by the Treaty on European Union of February 7, 1992. It is not clear why such communities should be denied the right to conceive of themselves as having a constitution, which has proven its worth as a means of integration and delimitation of competencies in similar contexts.

What is true for the domestic sphere is also true for international life. Here, too, communities and bodies with varying degrees of

92. See Peter Häberle, Verfassung als öfFentlicher PROzess: Materialien zU EINER VERFASSUNGSTHEORIE DER OFFENEN GESELLSCHAFT, chs. 4-7 and passim (2d ed. 1996) [hereinafter VERFASSUNGSTHEORIE].

93. PETER HÄBERLE, Verfassungsinterpretation als öffentlicher Prozess- ein Pluralismuskonzept, in VERFASSUNG ALS ÖFFENTLICHER PROZESS, supra note 92, at 121, 122.

94. ALLOTT, supra note 1 , at 167.

95. See Ingolf Pernice, Carl Schmitt, Rudolf Smend und die europäische Integration, 120 ARCHIV DES ÖFFENTLICHEN RECHTS 100, 117-18 (1995).

96. See COSTITUZIONE [COST.] arts. 114-133 (Italy); and CONSTITUCION [C.E.] arts. 143158 (Spain). 
autonomy have to play their role to meet the regulatory needs of the international community which "[n]ever before in history have ... been as acute as today." 97 It is precisely the process of expanding constitutionalism beyond the sovereign state in both directions, domestic and international, that gives evidence to the viability, adaptability and topicality of the idea of constitution. The fundamental rules of a system of governance concerning the scope and nature of its authority, the allocation of powers to specific organs, and the way these powers are to be exercised can be referred to as a constitution, even if that system is an international or supranational organization.

A process of gradual "constitutionalization" of a treaty-based public order is increasingly recognized in the case of the European Union. It is open to question whether the so-called primary law of the Union (the founding treaties) can be characterized as a "constitution," and what consequences would result from such a finding. This is not the place to join this discussion. Although there are, in the legal order of the Union and the United Nations, certain parallel developments, it must be borne in mind that the main reason for a constitutional perception of the E.U. is its gradual approximation of a state-like (federal) system. ${ }^{98}$ In our context, the debate is of interest only in so far as authors argue in favor, or against, the possibility of a constitutional foundation of a supranational community which is not, and does not necessarily have to become, a state.

Having untied the bond between state and constitution, one may also apply the term in the realm of universal international law without necessarily being a proponent of a "world state." An international constitution so understood is not bound to put an end to interstate relations based on international law. However, the use of a wider notion involves the need for distinguishing between different forms and categories of constitutions which have different legal effects. If local communities, "sovereign" states and supranational communities all can have constitutions, there cannot be just one type of constitution. The paradox is that while we seek to apply the notion to communities other than a state, essential characteristics of that notion-and exactly those intriguing us-developed when, and possibly because, it was closely connected with the modern state.

If there is a plurality of constitutions, the lawyer will wish to establish the relationship between them. At this moment, I only suggest

97. Tomuschat, supra note 68 , at 212 .

98. See, e.g., Eric Stein, Lawyers, Judges, and the Making of a Transnational Constitution, 75 AM. J. INT'LL. 1, 24 (1981). 
that, when determining their respective status in relation to "classical" state constitutions, one will have to distinguish between constitutions of domestic communities (like cities, regions and member states of federations) on the one hand, and those of supranational and international communities on the other. With regard to the former, their relationship is determined by the constitutional law of the state in question, while the status of the latter is established by international law.

The opposition of treaty and constitution referred to at the beginning of this section is far from self-evident. To the contrary, in the classical works of Hobbes, Grotius, Locke, and Rousseau the establishment of governmental power is seen as a result of a free association and agreement of individuals. "Men being ... by nature all free, equal, and independent," Locke said, "no one can be . . . subjected to the political power of another without his own consent, which is done by agreeing with other men, to join and unite into a community ...."100 In contemporary constitutional thought, the idea of a societal "fundamental consensus" and the need for its continuous renewal plays a significant role. ${ }^{101}$ To a part of the German constitutional movement of the nineteenth century, a constitution was a compact between the monarch and the people. Actual examples of such a Verfassungsvertrag, or consented constitution, are the constitutions of the kingdoms of Württemberg and Saxony of 1819 and 1831 , respectively. ${ }^{102}$ Recently, John Rawls' work has led to a revival of contractualism. ${ }^{103}$

There is another association of treaty and constitution in the form of a treaty by which several independent states establish a federation or confederation. ${ }^{104}$ German constitutional doctrine has called such an agreement a Bundesvertrag, or treaty-constitution. Historical examples are the "Articles of Confederation and perpetual Union" between the thirteen original United States of America of 1777, the Constitution of

99. See Jörg Fisch, Vertrag, Gesellschaftsvertrag, Herrschaftsvertrag, in 6 GESCHICHTLICHE GRUNDBEGRIFFE 901, 918-32 (Otto Brunner et al. eds., 1990). 1989).

00. JoHN LOCKE, Two TREATISES OF GOVERNMENT (1690) 164 (W.S. Carpenter ed.,

101. For an extensive discussion, see INGOLF PERNICE, BILLIGKEIT UND HÄRTEKLAUSELN IM ÖFFENTLICHEN RECHT 337-50 (1991).

102. For texts, see 1 AUSGEWÄHLTE URKUNDEN ZUR DEUTSCHEN VERFASSUNGSGESCHICHTE SETT 1806, at 44 and 113, respectively (Wilhelm Altmann ed., 1898) [hereinafter AUSGEWÄHLTE URKUNDEN].

103. See, e.g., JOHN RAWLS, A THEORY OF JUSTICE (1971).

104. For a recent reexamination of the concepts and their relation to that of modern intergovernmental organization, see THE MODERN CONCEPT OF CONFEDERATION 29, 42, 63 (European Commission for Democracy through Law ed., 1995). 
the United States of $1787,{ }^{105}$ the fundamental acts of the German Confederation of 1815 and $1820,{ }^{106}$ and the constitutions of the North German Confederation and the German Empire of 1867 and 1871, respectively. ${ }^{107}$ Although the term has not been used with regard to intergovernmental organizations of the twentieth century, it can generally give expression to the process of creating a new international or supranational body by way of an international treaty.

In the case of such a treaty-constitution, it is an open question which of its two constituents will be consolidated. If the first, i.e. the form of the instrument, prevails, the new corporation will have a separate legal personality but "no measure of independence or power to eradicate its subordination to its States' parents and its subjection to the classical laws governing the States' treaty relations .... . The basic principles of the law of treaties would apply to privilege the makers of the treaty at all critical junctures in the life of a treaty-treaty-making, amendment, interpretation and organization." 108 It is only if the second constituent succeeds, and substance triumphs over form, that the instrument will subordinate the constituent units to the new creation and will apply to each of them irrespective of their continuous individual consent. In spite of its origins, it becomes non-consensual or "autonomous." 109 While it is possible, and indeed not uncommon, to speak of a "constitution" also in the first case, the attribute distinctively characterizing a constitution is only present in the latter.

Whether the one or the other element will prevail, is partly determined by the language of the instrument. It may either stress the contractual basis of the association ${ }^{110}$ or its constitutional quality, for instance by referring to, or installing, a constituent power independent of the founding states. ${ }^{11}$

105. See U.S. CoNST. art. VII, cl. 2: "Done in Convention by the Unanimous Consent of the States present ...."

106. For texts, see AUSGEWÄHLTE URKUNDEN, supra note 102, at 9 and 73, respectively.

107. For texts, see 1867 BUNDESGESETZBLATT 2 and 1871 REICHSGESETZBLATT 63 , respectively; reprinted in 2 DOKUMENTE ZUR DEUTSCHEN VERFASSUNGSGESCHICHTE 272, 384 (Ernst Rudolf Huber ed., 3d ed. 1986).

108. Weiler \& Haltern, supra note 87, at 417-19.

109. Id. For the non-consensual character of the international constitution as understood by Professor Tomuschat, see supra text accompanying note 71 . For the concept of constitutional autonomy, see Theodor Schilling, The Autonomy of the Community Legal Order: An Analysis of Possible Foundations, 37 HARV. INT'L L.J. 389 (1996).

110. See, e.g., ARTICLES OF CONFEDERATION, art. 2 (U.S. 1781), and Final Act of the Conference of May 15, 1820, Constitution of the German Confederation, art. 2, 71 Consol. T.S. 89 ("mutual and equal contractual rights and obligations").

111. See, e.g., U.S. CoNST. pmbl. ("We the People of the United States ..."). 
As regards our subject, the possible constitutional quality of the U.N. Charter, this means that by simply describing it as a treatyconstitution in the sense stated above we could not arrive at a clear answer to our question. The term does not resolve the dichotomy between an international treaty and a (international) constitution. However, to the extent that a constitution of the international community can be conceived, the dichotomy between "the international" and "the constitutional" is overcome. What is therefore needed is a closer look at possible constitutional traits of the Charter.

\section{International Community and International Constitution}

In constitutional theory, there are two conflicting views as to the relationship between community and constitution. According to the first view, only a political community which is already there, not a plurality of unrelated individuals, can enact a constitution. In other words, the political entity (in particular, the state) comes first, its constitution follows. ${ }^{112}$ The second view assumes exactly the opposite when it sees a community as the result of a constitutive process. To Rudolf Smend, "state" as an empirical reality is continuously affected by a process of integration which is partly regulated by constitutional law. ${ }^{113}$ Hermann Heller explained that a political entity does not exist "as such," but as an organized body, its organization being dependent on rules. "In the case of a state, normativeness and existence do not conflict but are mutually dependent." 114

If one subscribes to the first view, one has to prove the existence of an international community as a pre-condition of the creation of a constitution applying to such a community. If one follows the second view, it is sufficient to demonstrate an occurrence of international constitution-making because a community will necessarily follow from such a constitutive act. The idea of a so-called treaty-constitution, which we addressed above, ${ }^{115}$ perfectly fits in with the second view-the making of such a constitution does not presuppose the existence of the community which is to be "constituted"; all that is required is that the states in question desire to establish such a constitution.

112. See SCHMTT, supra note 9, at 61-62. See also Josef Isensee, Staat und Verfassung, in I HANDBUCH DES STAATSRECHTS, supra note 56, at 591, 595.

113. See SMEND, supra note 6, at 78-85.

114. HELLER, supra note 10 , at $194,230$.

115. See supra text accompanying note 104. 
It seems that at least in the international sphere there is an interaction and reciprocal reinforcing of the two concepts of community and constitution, a dialectical relationship between the two which makes it futile to ask what has been, or has to be, first. "A society forms its constitution to bear its identity. But it also forms its constitution to shape its identity."116 Similarly Professor Tomuschat writes of an "interdependence that exists between the two concepts of international community and its constitution." 117 Even if one accepts both that from a theoretical and logical point of view a community can be created by the making of constitution and that its existence as a legal entity depends on its being constituted in such a way, its life will still be influenced by the measure of cohesion present at the moment of its constitutional birth. So much was even admitted by Smend and Heller. ${ }^{118}$ Therefore, I do not deem it superfluous to inquire into the present character of the international community. I will return to the two conflicting views when dealing with the question of homogeneity. ${ }^{119}$

Ubi societas, ibi jus, goes a Roman maxim. Whether this is true or not will depend on how one defines "society" and "law." Convinced that law requires the existence of a society as its substratum, generations of international lawyers have struggled to prove the existence of an international society in the face of war and hatred between nations.

An inversion of the saying is at least as valid: Ubi jus, ibi societas. Where individuals or legal persons enter into legal relationships-whether bilateral, multilateral, or constitutional-legal communities come into being. As soon as independent communities established legal relations with one another, an international system of corresponding size and character came into existence. However, "international community" as understood by the scholars introduced above goes beyond such a formal notion. Instead, it describes "an overarching system which embodies a common interest of all States and, indirectly, of mankind." 120 These scholars refer to article 53 of the

116. ALLOTT, supra note 1 , at 141 . Cf. id. at 338-39, figs. 11 and 12.

117. Tomuschat, supra note 68 , at 219 . Consider also J.L. Brierly's remark about the relationship between law and society: "Law can only exist in a society, and there can be no society without a system of law to regulate the relations of its members with one another." J.L. BRIERLY, THE LAW OFNATIONS: AN INTRODUCTION TO THE INTERNATIONAL LAW OF PEACE 41 (Sir Humphrey Waldock ed., 6th ed. 1963).

118. See SMEND, supra note 6, at 78, and HELLER, supra note 10, at 165-66, 239-40, 254 $55,277-79$.

119. See infra text accompanying note 128.

120. Tomuschat, supra note 68, at 227. See also HEDLEY BUL, THE ANARCHCAL SOCIETY: A STUDY OF ORDER IN WORLD POLITICS 13 (2d ed. 1995) ("A society of states (or international society) exists when a group of states, conscious of certain common interests and common values, form a society in the sense that they conceive themselves to be bound by a common set 
Vienna Convention on the Law of Treaties which, in order to define rules of jus cogens, introduced the notion of "the international community of States as a whole" in the language of multilateral treaties ${ }^{121}$ and to the category of "obligations erga omnes" as acknowledged by the International Court of Justice in its Barcelona Traction decision. ${ }^{22}$ They also attach importance to the fact that the General Assembly and the Security Council, as well as the world conferences organized under the auspices of the U.N., frequently address the "international community." This is sometimes defined as the global community of states (as in the two Vienna Conventions), sometimes as a community consisting of states and intergovernmental organizations, and sometimes as a collective name for states, intergovernmental organizations and NGO's. In the final paragraph of its Declaration on the Occasion of the Fiftieth Anniversary of the U.N., the General Assembly used a still broader notion when it

recognize[d] that our common work will be the more successful if it is supported by all concerned actors of the international community, including non-governmental

of rules in their relations with one another, and share in the working of common institutions.").

121. For text of the article, see 8 I.L.M. 679, at 698 (1969). The provision has been copied verbatim in article 53 of the Vienna Convention on the Law of Treaties Between States and International Organizations or Between International Organizations of 1986, 25 I.L.M. 543, at 572 (1986).

122. See Barcelona Traction (Belg. v. Spain), 1970 I.C.J. 1970, 3, at 32, paras. 33-34 (Feb. 5). Article 19(2) of the draft articles on state responsibility (part 1) adopted by the I.L.C. on first reading on July 25, 1980, defines an "international crime" as follows: "An internationally wrongful act which results from the breach by a State of an international obligation so essential for the protection of fundamental interests of the international community that its breach is recognized as a crime by that community as a whole constitutes an international crime." Report of the International Law Commission, U.N. GAOR, Supp. No. 10, U.N. Doc. A/35/10 (1980); 2 Y.B. INT'L L. COMM'N, pt. 2, 30, 32 (1980) (emphasis added).

According to Article 26(2a) of the draft statute for an international criminal tribunal prepared by a working group of the I.L.C. in 1993, the tribunal should, under the conditions set out in paragraph 1 of the Article, have jurisdiction in respect to "crimes under general international law, that is to say, under a norm of international law accepted and recognized by the international community of States as a whole as being of such a fundamental character that its violation gives rise to the criminal responsibility of individuals." Report of the International Law Commission, U.N. GAOR, Supp. No. 10, U.N. Doc. A/48/10 (1993); 2 Y.B. INT'L L. Comm'N, pt. 2, 100, 109 (1993) (emphasis added). However, the provision was not included in the draft statute for an international criminal court adopted by the I.L.C. on July $21,1994$. In addition to the crimes already made punishable at Nuremberg, Article 20(e) of the draft statute only refers to "crimes ... which, having regard to the conduct alleged, constitute exceptionally serious crimes of international concern." Report of the International Law Commission, U.N. GAOR, Supp. No. 10, U.N. Doc. A/49/10, 43, 70 (1994) (emphasis added). For further examples of a normative recognition of the international community, see DANILENKO, supra note 68, at 12-13. 
organizations, multilateral financial institutions, regional organizations and all actors of civil society. ${ }^{123}$

According to Professor Abi-Saab, "identité [de système juridique] est en premier lieu celle de la base idéologique ou de la source de légitimité de l'ordre juridique ... dans le milieu social où il s'applique." 124 The proposition appears to be well-founded that today the international community can be identified by its agreement upon such "sources of legitimacy." Thus, the international legal community - corollary of any international law-has taken on a new quality. It can no longer be simply described as a Genossenschaft, or association of equals not subordinated to any higher authority and exclusively associated by agreement. The community is meant to be more than the sum of its constituent parts; it does not express a mere volonté de tous but a volonté générale. ${ }^{125}$ As Judge Lachs put it, "le réseau de coopération internationale a dépassé le stade du "lien contractuel'."126 In order to signify this difference, one may refer to the traditional system as "international society," and to the new one as "international community."

The question ensues whether the present international community is formed in a way which allows it to have, or to bring forth, a constitution in the meaning described above, i.e., whether it can be referred to as a constitutional community. ${ }^{127}$ To Carl Schmitt, any association of political communities requires, as an essential prerequisite, a certain homogeneity of its members, that is "a substantial similarity which establishes a concrete and real correspondence between the member states that prevents the occurrence of the extreme conflict within the

123. Declaration on the Occasion of the Fiftieth Anniversary of the United Nations, G.A. Res. 50/6, U.N. GAOR, para. 17 (1995). See also Mohammed Bedjaoui, General Introduction, in INTERNATIONAL LAW: ACHIEVEMENT AND PROSPECTS 1, at 5, para. 11 (M. Bedjaoui gen. ed., 1991). In contrast, Philip Allott defines international society as "the social becoming of five billion human beings and of uncounted subordinate societies." ALLOTT, supra note 1, at 415, 306,411 . For my (more conventional) definition, see infra text accompanying note 240.

124. Georges Abi-Saab, "Humanitê" et "communauté international" dans la dialectique du droit international, in HUMANTTÉ ET DROT INTERNATIONAL: MÉLANGES RENÉ-JEAN DUPUY 1, 2 (1991).

125. See Michael Koch, Comment, in ALlocation OF LaW ENFORCEMENT AUTHORITY IN THE INTERNATIONAL SYSTEM 178 (Jost Delbrück ed., 1995) [hereinafter ALLOCATION OF LAW ENFORCEMENT AUTHORITY].

126. Lachs, supra note 76 , at 355.

127. In 1934, Georges Scelle still answered this question in the negative, holding that "[d]ans les milieux internationaux, l'ordre juridique constitutif ou constitutionnel est, la plupart du temps, trop insuffisamment évolué pour que l'on puisse songer à la rédaction d'une charte." SCELLE, supra note 71 , at 9-10. 
association." 128 This view is based on the belief that the existence of any political entity, in particular the state, depends on a "substantial similarity" of its constituent members. It is an overstatement of the interdependence of law and the rest of the social process. ${ }^{129}$

Hermann Heller rejected Schmitt's concept, which he traced back to Rousseau, the age of Romanticism and Hegel, holding that empirically peoples and nations are not homogeneous entities but rather characterized by all sorts of economic, intellectual or denominational differences. "Relative homogeneity [of a people] can be one of the causes of the unity of a state, but it can also be an effect of that very unity." But, Heller said, it is never this homogeneity alone by which a state is established. Instead, in the end a state results from conscious human action, an act of organization. ${ }^{130}$

With regard to the international community, Hedley Bull has suggested a sort of homogeneity which turns Schmitt's concept upside down: "The future of international society is likely to be determined ... by the preservation and extension of a cosmopolitan culture, embracing both common ideas and common values, and rooted in societies in general as well as in their elites."131

Variety, differences, opposites are the characteristic features of life on this planet, and nobody intends to level them. Schmitt's "substantial similarity" contrasts sharply with the very idea of the international community. What is decisive, and sufficient, is that there is core area of agreement on how to behave.

Differences and even contradictions, clashes of interest, disputes over the distribution of the world's resources ... do not impede a basic consensus about the necessity commonly to salvage the globe's life supporting capacity and to maintain a minimum standard of mutual respect as outlined in the Charter of the United Nations and the other great texts defining the realm of common agreement. ${ }^{132}$

128. SCHMITT, supra note 9, at 375-76. For critique, see J.H.H. Weiler, The State "über alles": Demos, Telos and the German Maastricht Decision, in 2 FESTSCHRIFT FÜR ULRICH EVERLING, supra note 87, at 1651, 1655-63, 1670-83; and Pernice, supra note 95, at 105-08, 110-11 (waming that to Schmitt "substantial similarity" of a community implies its preparedness to exclude or destroy what is dissimilar).

129. For the view that "law and the rest of the social process are integral to each other," see ALLOTT, supra note 1, at 317.

130. See HeLleR, supra note 10, at 163-66, 230. See also id. at 194-95, 230, 243.

131. BUL, supra note 120 , at 305.

132. Tomuschat, supra note 68 , at 237-38. See also Henkin, supra note 42 , at 358 . 
The prohibition on the use of force, the obligation to respect fundamental human rights, and the obligation to protect the natural environment as far as this is a prerequisite of common survival are rules based upon universal agreement-notwithstanding the fact that they are open to interpretation and not always observed. It may also be pointed out that, in international relations, there is a U.N. "monopoly on the legitimate use of physical force"-a monopoly which, in the domestic sphere, is held by the state. Since Thomas Hobbes, "Common Peace and Safetie" is the primary raison d'être of the modern state. The commitment of the Soviet Union and its allies to obeying the mentioned rules could hardly be taken at face value, and the "Cold War" also prompted Western states to violate international law, but the demise of communism has significantly strengthened the respective international consensus.

The international community thus is a community based on an agreement on rules. Common belief in a number of elementary rules generates law, and this law reinforces the sense of community. That is all the homogeneity which is needed.

This it not meant to belittle the shortcomings in the way the community has reacted to violations of its rules. Its passivity with regard to the massive war crimes and human rights violations committed on the territory of the former Yugoslavia, in Rwanda, and in Zaire (Congo) is still fresh in everybody's mind. One cannot but agree with Professor Weiler who, in 1993, remarked that "the paralysis of the U.N., the powerlessness of its peace-keeping forces and the inaction of Europe-forever canvassing, discussing, consulting, debating, communicating, and refining while the decimation goes on-are frustrating, mind numbing, soul chilling." 133 However, different from the past there is at least a common awareness both of the need for community action and the inadequacy of the actual response.

In conclusion, the international community, as it exists today, provides a sufficient social basis for a constitutional charter, a charter which, as an element of a broader process of integration, will further strengthen the unity of the community it governs.

\section{International Community, Constitution, and Organization}

In principle, there cannot be a community, understood as a distinct legal entity, in the absence of a constitution providing for its own

133. Joseph H.H. Weiler, Editorial, 4 EuR. J. INT'LL. 157 (1993). 
organs. Legal personality requires the actual ability to perform legal acts.

An international community without institutions able to represent it would be a legal anomaly, a phenomenon with blurred contours always at risk of being called into question. For this reason, too, there is an inevitable relationship between the concepts of international community and international constitution. Not only does the constitution need a community as its substratum in social reality, but the community also needs to be constituted. In the absence of organs clearly entitled to voice the opinions, and to apply and enforce general laws of the international community, the process of the community's "constitutionalization" is not complete. Dédoublement fonctionnel will not do any more in a community of the sort outlined here, just as it appears inconceivable to leave law enforcement and adjudication in a state solely, or even mainly, in the hands of individuals. ${ }^{134}$

The United Nations is the primary institutional representative of the international community. From a constitutional point of view, it would be unsatisfactory to regard an undefined number of intergovernmental organizations and international conferences as organs of the international community. Such a plurality of voices would necessarily result in contradictions and ambiguities which are the exact opposite of what any legal community must strive to realize-clarity, transparency and reliability of the law. Compared to "functional" universal organizations established to further cooperation of states in narrowly defined fields like postal services, agriculture, industrial development, etc., the U.N. has a much broader, and more political, mandate. According to article 1 of the Charter, its purposes are, inter alia, to "maintain international peace and security," to "develop friendly relations among nations," and to "achieve international cooperation in solving international problems of an economic, social, cultural, or humanitarian character." The special case of the Republic of China (Taiwan) left aside, today only Switzerland, the State of the Vatican City, Kiribati, Tuvalu, Tonga and Nauru do not belong to the U.N. The U.N. General Assembly is the only body whose resolutions have been attributed binding legal quality by a number of governments and eminent

134. For G. Scelle's idea of "dédoublement fonctionnel des compétences gouvernementales," according to which "chaque organisation étatique joue son rôle législatif, judiciaire, exécutif, comme une sorte de section ou de circonscription des communautés internationales particulières ou générales," see SCELLE, supra note 71, at 10-12. 
scholars. ${ }^{135}$ Moreover, the U.N. is the only global body with potentially strong executive powers and a judicial organ with a significant jurisdiction. As Professor Antonio Cassese said, "the U.N. ultimately acts in the interest and on behalf of the whole world community, of which it is the legitimate representative." 136

If, therefore, under the present circumstances, the U.N. appears to be the institution furnishes the international community with organs, the next step would be to examine whether the U.N. Charter can indeed be considered as the constitution of this very community. In consequence, the Charter would not only be the founding instrument of the United Nations Organization, but it would also constitute-as a constitutional instrument-the international community as a whole.

\section{THE U.N. Charter AS A CONSTITUTION}

Professors Verdross' and Simma's reasoning is based on state consent. In 1945, the authors say, the Charter was the constitution of the United Nations Organization, an association of states within the universal legal community. Since in the meantime almost all states have acquired membership in the U.N. and the few states remaining outside the organization have recognized its main principles, the Charter has now become the "constitution of the universal community of states."

This concept is not revolutionary. If the founding treaty of an international organization is called its constitution, and this organization acquires universal membership, one can of course speak of a "constitution of the universal community of states." What is problematic is the position of non-member states under the Charter. The respective doctrinal problems are not convincingly solved by any of the scholars discussed above. Judge Mosler approves of measures of the Security Council against non-member states without giving any reasons. ${ }^{137}$ Professors Verdross and Simma, as well as Professor Tomuschat, would

135. For an overview, see BLAINE SLOAN, UnITEd NATIONS GenERAL AsSEMBly REsolutions IN OUR CHANGING WORLD ch. 2 (1991). See also Military and Paramilitary Activities in and Against Nicaragua (Nicar. v. U.S.), 1986 I.C.J. 14, 99-100, para. 188 (June 27).

136. ANTONIO CASSESE, INTERNATIONAL LAW IN A DIVIDED WORLD 159 (1986). Consider also Scelle's remark about the U.N.s predecessor, the League of Nations: "La Societé doit tendre à se degager de l'emprise des gouvernements, à acquerir une vitalité propre, et à organiser économiquement et juridiquement la communauté internationale." G. Scelle, L'admission des nouveaux membres de la Société des Nations, 28 REVUE GÉNÉRALE DE DROIT INTERNATIONAL PUBLIC 122, 138 (1921).

137. See supra text accompanying note 67. 
have the Council act as an agency of states on the basis of general international law-a construct hardly convincing and inconsistent with their own premises. ${ }^{138}$ The entire practice of the Council since 1977, when it began to address its Chapter VII based decisions to "all States,"139 and this to non-members, finds no explanation.

\section{A. The "Ideal Type" of a Constitution}

In order to ascertain whether a specific set of rules can be referred to as the, or as a part of the, constitution of the international community, we need to define such a constitution. As I tried to demonstrate above, there is no general agreement as to what makes a "constitution."

It seems that if we want to attribute constitutional quality to the U.N. Charter, we would best apply the fairly broad definition of constitution developed by Rudolf Smend or Peter Häberle. The idea is tempting, but in the end not convincing. The Smend and Häberle sought to explain the place and function of a constitution as a part of a national legal and societal order. Smend emphasized the role a constitution plays in the larger process of integration of a state. He did not say that wherever a legal document plays a significant role in integrating a community, it is a constitution. Häberle held that the interpretation and application of a constitution is an open and public process involving many institutions and individuals. He did not say that any process of that kind is a constitution. Even if we called the Charter a constitution, it would be hard to say that certain normative consequences result from that finding.

At the end of my brief survey, I pointed out that contemporary written constitutions are almost universally distinguished by a number of characteristics. ${ }^{140}$ These are sets of fundamental norms about the organization and performance of governmental functions in a community, and the relationship between the government and those being governed. The instruments shall, in principle for an indefinite period of time, provide a legal frame and guiding principles for the political life

138. See VERDROSS \& SiMMA (3d ed.), supra note 41, at 177; Tomuschat, supra note 68 , at 253.

139. See S.C. Res. 418, U.N. SCOR, 48th Sess., 2046th mtg., para. 2, U.N. Doc. S/RES/418 (1977), reprinted in 1977 U.N.Y.B. 161. For a recent example, see S.C. Res. 1070, U.N. SCOR, 51st Sess., 3690th mtg., U.N. Doc. S/RES/1070 (1996) (Sudan) ("The Security Council ... acting under Chapter VII of the Charter . . . . [d]ecides that all States shall deny aircraft permission to take off from, land in, or overfly their territories if the aircraft is registered in Sudan ....").

140. See supra text accompanying note 20 . 
of a community. They are binding on governmental institutions and community members alike, and paramount law in the sense that law of lower rank has to conform to the constitutional rules. At a later point, I explained that the political community in question does not necessarily have to be a state. ${ }^{141}$

It is this normative notion of constitution on which we base our analysis of the U.N. Charter. The point of reference is an ideal type of constitution established according to Max Weber's methodology.

Weber's ideal type (ideal not in the sense of perfect or best, but as opposed to "real") of a phenomenon or development, be it sociological or normative, is determined by intentionally intensifying and combining one or more of its individual features to form a consistent theoretical construct. $^{142}$

[The ideal type] is a theoretical construct which is neither historical nor "true" reality ... . Instead, it is a purely ideal, or imagined, "border-notion" (Grenzbegriff) - a yardstick or standard to which reality is compared in order to elucidate certain significant elements of its empirical substance .... It is its purpose to show as clearly as possible the individuality of cultural phenomena. ${ }^{143}$

Today a solely inductive, necessarily descriptive, construction of constitution in the normative sense could not lead us beyond the range of state constitutions. Although sometimes called "constitutions," the international treaties establishing intergovernmental organizations generally lack the legal autonomy as well as the political quality of a normative constitution. ${ }^{144}$ All we could arrive at is an abstract form of constitution of a (sovereign) state which then could be placed next to the Charter in order to expose similarities and differences.

The ideal type method, however, allows us to leave the element of state out of an account because we do not regard it as an essential

141. See supra text accompanying note 87 et seq.

142. See Max Weber, Die "Objektivität" sozialwissenschaftlicher und sozialpolitischer Erkenntnis (1904), reprinted in GESAMMELTE AUFSÄTZE ZUR WISSENSCHAFTSLEHRE 146, 190 91 (Johannes Winckelmann ed., 7th ed. 1988) [hereinafter Weber, Objektivität]. For a shorter explanation, see MAX WEBER, WIRTSCHAFT UND GESELLSCHAFT: GRUNDRISS DER VERSTEHENDEN SOZIOLOGIE 9-11 (Johannes Winckelmann ed., 5th ed. 1972). For its translation, see MAX WEBER, SELECTIONS IN TRANSLATION 23-25 (W.G. Runciman ed., E. Matthews transl., 1978).

143. Weber, Objektivität, supra note 142, at 194, 202. For a similar method of constructing "analytical-synthetic generalizations" in the form of "generic principles which are shared by all the constitutions of all societies," see ALLOTT, supra note 1, at 167-70.

144. See supra text accompanying note 109. 
characteristic of a constitution. ${ }^{145}$ Nevertheless, we still draw on an institution and process of municipal law, although traditionally international lawyers have argued against such an approach "as betraying a regrettable tendency to imitation, as ignoring the special structure of international relations, and as threatening to thwart, by introducing technicalities and intricacies of municipal jurisprudence, every attempt at a fruitful and creative scientific activity in the domain of international law."146

Having examined the practice of states particularly regarding the use of private law, Professor $\mathrm{H}$. Lauterpacht repudiated this view, holding that

there is in the constant recourse to analogy something more than a peculiarity of one historical period. A critical examination shows that the use of private law exercised, in the great majority of cases, a beneficial influence upon the development of international law; that in other cases international law ultimately adopts solutions suggested by private law, without paying regard to the so-called special character of international relations; that it adopts, even now, notions of private law whenever exigencies of international life seem to demand such a solution ..... ${ }^{147}$

According to Arnold McNair, Lauterpacht's investigation "vindicate[d] the practice of resort to rules and conceptions of private law for the purpose of the development of international law." 148 Later, when sitting on the I.C.J., Sir Arnold remarked that "[i]nternational law has recruited and continues to recruit many of its rules and institutions from private systems of law." 149 Indeed, in historical perspective the idea of constitution would only be the latest of many legal concepts which first took shape in a domestic context and were later applied to international law. Treaty and custom as sources of law, the doctrine of subjects of law, the court as a means of interpretation of law and dispute settlement-these are all concepts that unfolded, understandably

145. See supra text accompanying note 88 .

146. H. LAUTERPACHT, PRIVATE LAW SOURCES AND ANALOGIES OF INTERNATIONAL LAW (WITH SPECIAL REFERENCE TO INTERNATIONAL ARBITRATION) vii (1927). For a recent examination, see M. Shahabuddeen, Municipal Law Reasoning in International Law, in FIFTY YEARS OF THE INTERNATIONAL COURT OF JUSTICE: ESSAYS IN HONOUR OF SIR ROBERT JENNINGS 90 (Vaughan Lowe \& Malgosia Fitzmaurice eds., 1996).

147. LAUTERPACHT, supra note 146 , at viii.

148. LAUTERPACHT, supra note 146, at v (foreword by Amold D. McNair).

149. International Status of South-West Africa, 1950 I.C.J. 128, 148 (July 11) (McNair, J.. sep. op.). See also South West Africa Cases (Second Phase), 1966 I.C.J. 6, 294-95 (July 18) (Tanaka, J., dissenting). 
enough, in legal settings the development of which preceded that of the international community. The "general principles of law recognized by civilized nations" referred to in Article 38 of the I.C.J. Statute are defined by many writers to include principles common to all or "the principal legal systems of the world." 150 In our time, international law is about to adopt the concept of individual criminal responsibility beyond the narrow field of violations of humanitarian law. ${ }^{151}$ An institution of public law, a constitution seems to be even better suited to be applied in public international law than concepts of domestic private or criminal law. ${ }^{152}$ On the other hand, it must be admitted that it was comparatively easier to introduce rules and institutions of private law, as a system of coordination, into an order understood as a law of equals than it is to introduce constitutional rules implying a relationship of subordination. There had to be a fundamental change in our perception of the international community before one could think of drawing on constitutional law.

There is a difference between relying on a rule of municipal law for the solution of a specific case and looking at certain institutions common to a multitude of national legal systems in order to explain facts and conditions in international law which already exist as a matter of fact but are not yet adequately understood. The latter type of activity cannot be criticized as hampering a "fruitful and creative scientific activity" in international law. Rather, one is merely drawing on conditions and institutions of municipal law "for the purpose of appreciating a concept or solving a problem in international law which is materially similar to a corresponding concept or problem in municipal law." ${ }^{153}$ By necessity, such an analysis must reveal differences and, thus, the peculiarity of the international constitutional order. The constitutional idea in international law will become apparent as an autonomous concept rather than an extrapolation of the law of a particular state or states, ${ }^{154}$ it will eventually emancipate itself from its origins, and it will

150. See Statute of the I.C.J., signed June 26, 1945, art. 9, 59 Stat. 1055, 33 U.N.T.S. 993. [hereinafter Statute of the I.C.J.]; VERDROSS \& SiMMA (3d ed.), supra note 41, at 382-87; and VERDROSS, supra note 43, at 124-28 (with an overview of arbitral decisions).

151. See Draft Code of Crimes against the Peace and Security of Mankind, U.N. GAOR, 48th Sess., Supp. No. 10, at 9-120, U.N. Doc. A/51/10 (1996).

152. For a recourse to municipal constitutional law in regard to the law of international organizations, see Michael Bothe \& Georg Ress, The Comparative Method and Public International Law, in INTERNATIONAL LAW IN COMPARATIVE PERSPECTIVE 49, 53-57 (William E. Butler ed., 1980), and Bernard Dutoit, Comparative Law and Public International Law, in id. at $67,79-85$.

153. Shahabuddeen, supra note 146 , at 92 .

154. $C f$. THOMAS M. FRANCK, FAIRNESS IN INTERNATIONAL LAW AND INSTITUTIONS 85 (1995). 
no longer be necessary to go back to its historical and theoretical point of departure.

\section{B. Constitutional Characteristics of the U.N. Charter}

A number of features of the ideal constitution, as conceived according to Max Weber's methodology, may be recognized in the Charter.

\section{A "Constitutional Moment"}

It was evident to participants in the San Francisco Conference and observers alike that the drafting of the Charter was a true "constitutional moment" in the history of international law. ${ }^{155}$ The delegates were confronted with a profound transformation of the international order that had already begun with World War I, and they sought to stabilize the new situation. "A constitution outlines the program that legitimizes the new order." 156 Reading the Charter, in particular its Preamble and Chapter I, in light of this observation, one clearly recognizes the will of its drafters firmly to establish a new world order in which international peace and security would be safeguarded, and friendly relations among nations promoted. The broad powers conceded to the Security Council, as well as Articles 2, paragraph 6, and 103, indicate a renunciation of the traditional concepts of sovereignty and bilateralism. Hans Kelsen characterized the claim made by the Charter on non-member states as "revolutionary" and added, "Whether it will be considered as a violation of the old, or as the beginning of a new international law, remains to be seen." "157 Although formally established on the basis of international law in force at the time, the Charter was indeed meant to mark "a new stage in the course of history." 158 The new order is described in a typically constitution-like manner-in a short and clear text establishing the most important goals and policies of the newly defined community.

These facts were rendered obscure during the long years of the Cold War when international law and politics resembled so much

155. The term is borrowed from BRUCE ACKERMAN, WE THE PEOPLE: FOUNDATIONS (1991), passim.

156. Isensee, supra note 112 , at 594.

157. HaNs Kelsen, THE LaW OF THE UNITEd Nations 110 (1950).

158. Aegean Sea Continental Shelf Case (Greece v. Turk.), 1976 I.C.J. 3, 33 (Sept. 11) (Tarazi, J., sep. op.). See also CASSESE, supra note 136, at 222 ("The system inaugurated in 1945 was revolutionary indeed."). 
classical pre-war balance of power-exercises. It is only now that the almost revolutionary approach of the Charter is being rediscovered.

The past is always prologue to the present. ${ }^{159}$ No constitution can ignore or deny it. By necessity, even a revolutionary constitution that aggressively turns against the previous legal order takes account of it. It is therefore not unusual that a constitution incorporates law of the past. Thus, we can readily accept the proposition that the Charter partly reflects constitutional principles which were in force long before the Charter was drafted. But the word "reflect" does not comprehensively describe what the Charter has done to these primordial rules. By embracing or incorporating them, it has also confirmed them-given them a place in the new order.

\section{System of Governance}

It is the minimum quality of any constitutional instrument that it provides for the performance of basic functions of governance, that is to say, making and applying the law and adjudicating legal claims. It has rightly been observed that the three functions are performed by the international community, though still in a way much less refined than in developed national systems of law. The Charter includes express provisions relating to legislation, application of law, and adjudication. Leaving aside the stale question of the lawmaking capacity of the General Assembly, there is no doubt about the right of the Security Council to enact "secondary law" according to Chapter VII of the Charter. Different from a typical national legislative body, and in accordance with the current state of constitutional development of the international community, the scope of law the Council can decree is limited ratione materiae. The maintenance and restoration of peaceful relations between the members of the community, however, is a task not to be underestimated. "[T]o protect and safeguard peace and security is the key function of governance in any human community." 160 In the absence of peace, no other governmental activity can properly be carried out. The recent past has, moreover, witnessed an increasingly broad definition of the notion of "international peace and security" by the Council, which allowed it to take action in situations previously considered to be of an essentially domestic character.

The Security Council is not only the most important lawmaking body of the United Nations, but it is also the central executive agent. It

159. See William Shakespeare, THE TEMPEST, act 2 , sc. 1.

160. Tomuschat, supra note 68 , at 334 . 
is the Council itself which, according to the Charter, shall enforce its decisions. Article 43 of the Charter envisages a strong executive element in the form of armed forces of member states to be made available to the Security Council.

Apart from the Security Council, the executive power is little developed in the scheme of the Charter. Some administrative tasks are allotted to the General Assembly, ECOSOC, and the Trusteeship Council. ${ }^{161}$ The Secretary-General is meant to be not much more than an officer assisting the other principal organs in the performance of their duties. Perhaps Chapter XV of the Charter is the clearest evidence of the intention of the founding members not to install a "world government." But again, largely due to the Cold War stalemate in the Security Council, the role of the Secretary-General in the prevention or resolution of international conflicts was expanded. In particular, the performance of the good offices function has rightly been called "the most crucial indicator of the Secretary-General's evolving constitutional role within the U.N. system." 162

Compared to mature domestic constitutional structures, the judicial function, as provided for in Chapter XIV of the Charter, is as underdeveloped as the legislative and executive. The International Court of Justice does not have compulsory jurisdiction over international disputes, ${ }^{163}$ and members of the international community other than sovereign states have no standing in the Hague at all. Less critical is the fact that the I.C.J., "the principal judicial organ of the United Nations", ${ }^{164}$ has no contentious jurisdiction over disputes arising between the principal organs of the U.N. or between member states and the U.N., nor is it prima facie empowered to invalidate U.N. legal acts. Only a minority of states with undoubtedly constitutional systems of government have established courts with such sweeping powers. ${ }^{165}$ Finally, it should be mentioned that the Security Council, in spite of its prevailing political character, also performs a semi-judicial function when recommending terms of settlement of international disputes or

161. See U.N. CHARTER, arts. 15-17, 60, 63, 66, 68, 85 and 87.

162. Thomas M. Franck \& Georg Nolte, The Good Offices Function of the UN SecretaryGeneral, in UNITED NATIONS, DIVIDED WORLD: THE UN'S ROLES IN INTERNATIONAL RELATIONS 143, 144 (Adam Roberts \& Benedict Kingsbury eds., 2d ed. 1993).

163. See Statute of the I.C.J., supra note 150, art. 36 .

164. U.N. CHARTER art. 92.

165. For an overview of courts outside the United States being empowered to settle dispute between state organs, and to judicial review, see HENRY J. ABRAHAM, THE JUDICIAL PROCESS 270-71, 288-300 (6th ed. 1993). 
situations which might lead to international friction (see Chapter VI of the Charter). ${ }^{166}$

The central role of the Security Council in the U.N. "system of governance" does not allow us to speak of a true separation of powers in the organization. ${ }^{167}$ The Charter assigns, nonetheless, different (limited) powers and tasks to different organs and establishes, to some degree, a system of checks and balances. ${ }^{168}$ Strict separation of powers cannot be regarded as an essential feature of constitutionalism because many constitutional systems, especially those of the parliamentary type, provide for some sort of exception. ${ }^{169}$ In this regard too, the U.N. can be understood as a rudimentary constitutional order capable of being developed into a more sophisticated state in the future. As Judge Weeramantry, referring to the Security Council and the I.C.J., wrote in his dissenting opinion in the Lockerbie case,

[a]s with the great branches of government within a domestic jurisdiction such as the executive and the judiciary, they perform their mission for the common benefit of the greater system of which they are a part. In the United Nations system, the sphere of each of these bodies is laid down in the Charter, as within a domestic jurisdiction it may be laid down in a constitution. ${ }^{170}$

\section{Definition of Membership}

Generally a constitution defines the members of the respective community, either explicitly ${ }^{171}$ or tacitly by reference to inherited and unchallenged rules. Chapter II of the Charter sets out rules regarding the acquisition, suspension and loss of membership in the organization.

166. See, e.g., ELIHU LAUTERPACHT, ASPECTS OF THE ADMINISTRATION OF INTERNATIONAL JUSTICE 37-48 (1991). It seems that it was Kelsen who first referred to the Security Council and the General Assembly as "quasi-judicial organs of the United Nations." KELSEN, supra note 157 , at $476-77$.

167. See Questions of Interpretation and Application of the 1971 Montreal Convention Arising from the Aerial Incident at Lockerbie (Libya v. UK; Libya v. U.S.), 1992 I.C.J. 3, 114, at 55, 165 (Apr. 14) (Weeramantry, J., dissenting) [hereinafter Lockerbie]. See also id. at 26, 138 (Lachs, J., sep. op.).

168. Professor Allott describes the principle of the intrinsic limitation of power ("all legal power is limited") as one of the generic principles of a constitution. ALLOTT, supra note 1, at $168,173-74$.

169. For a respective survey of European constitutional systems, see CONSTANCE GREWE \& HÉlÈNE RUIZ FABRI, DROITS CONSTITUTIONNELS EUROPÉENS 366-83 (1995).

170. Lockerbie (Weeramantry, J., dissenting), 1992 I.C.J. at 165.

171. See, e.g., U.S. CONST. amend. XIV, $§ 1, \mathrm{cl} .1$, and GRUNDGESETZ [Constitution][GG] art. 116 (F.R.G.). 
It must be admitted, though that today they appear incomplete (no community members but sovereign states are considered) and, as regards admission and expulsion, out of line with the actual state of law. ${ }^{172}$

\section{Hierarchy of Norms}

Another characteristic feature of any constitution is that it establishes a hierarchy of norms. After the constitution has entered into force, rules claiming to be law of the respective society must be in conformity with the standards determined by the constitution. Following Article 20 of the Covenant of the League of Nations, which led Professor Lauterpacht to attribute the character of "higher law" to that instrument, ${ }^{173}$ the Charter clearly gives expression to such a hierarchical model: "In the event of a conflict ... [the] obligations under the present Charter shall prevail". ${ }^{174}$ The precedence of the Charter has been recognized in multilateral treaties and General Assembly resolutions, as well as in draft articles adopted by the International Law Commission. ${ }^{175}$ It was emphasized by the I.C.J. in its order in the Lockerbie case and provided the basis of its denial of provisional measures. ${ }^{176}$ As Professor Tomuschat wrote,

172. For a discussion of membership of the international community, and of admission and expulsion of U.N. member states, see infra text accompanying notes 240 and 284 et seq.

173. See H. Lauterpacht, The Covenant as the "Higher Law", 17 BRIT. Y.B. INT'L L. 54 (1936).

174. U.N. CHARTER art. 103.

175. See Vienna Convention on the Law of Treaties, opened for signature May 23, 1969 , art. 30(1), 1155 U.N.T.S. 331; Vienna Convention on Treaties with and between International Organizations, Mar. 21, 1986, art. 30(6), 25 I.L.M. 543; Declaration on Principles of International Law concerning Friendly Relations and Co-operation among States in Accordance with the Charter of the United Nations, Annex to G.A. Res. 2625, U.N. GAOR, 25th Sess., Supp. No. 28, U.N. Doc. A/8028 (1970), reprinted in 9 I.L.M. 1292 (1970) [hereinafter Declaration of Friendly Relations] (principle of good faith, last paragraph); article 39 of the I.L.C.'s Draft Articles on State Responsibility (former article 4 of Part II), Report of the International Law Commission, U.N. GAOR, Supp. No. 10, U.N. Doc. A/51/10, 121, at 139 (1996).

176. See Lockerbie, 1992 I.C.J. 15, paras. 39-41, and 126-27, paras. 42-44, respectively. See also id. at 28-29, 140-41 (Shahabuddeen, J., sep. op.) (quoting Nicaragua, 1984 I.C.J. 440, para. 107); id. at 47, 157, paras. 29-30 (Bedjaoui, J., dissenting); id. at 60-61, 67, 170-71, 177 (Weeramantry, J., dissenting). See Vera Gowlland-Debbas, The Relationship between the International Court of Justice and the Security Council in the Light of the Lockerbie Case, 88 AM. J. INT'LL. 643, 647-48 (1994). See also Effect of Awards of Compensation Made by the United Nations Administrative Tribunal, 1954 I.C.J. 76, 83 (July 13) (Hackworth, J., dissenting), quoted in Land, Island and Maritime Frontier Dispute (El Sal. v. Hond.), 1990 I.C.J. 18, 49 (Feb. 28) (Shahabuddeen, J., dissenting) ("The duty of a court when faced with apparent incompatibility between a legislative enactment and the constitution (the Charter) is to try to reconcile the two. If this cannot be done the constitution must prevail."). 
it is not easy to explain why the Charter should take [such] precedence .... The fact is, however, that the purported effect of Article 103 has never been called into question. According to all probability, states today view the Charter as the constituent instrument of the international community, which sets the framework for any permissible governmental activity. ${ }^{177}$

\section{5. "Eternity" and Amendment}

The French Constitution of 1793 held that no generation can subject future generations to its laws. ${ }^{178}$ And yet, another distinguishing quality of a constitution is its claim to be valid regardless of the passing of time. Every constitution aspires to eternity. The Charter, too, makes such a claim. It only provides for amendment, not for termination. ${ }^{179}$

According to Articles 108 and 109, amendments to the Charter come into force for all U.N. members when they have been adopted by a two-thirds majority of the General Assembly, or the General Conference, respectively, and ratified by two thirds of the member states, including the permanent members of the Security Council. There is a striking difference between that rule and the one traditionally applied to the amendment of international treaties - the requirement of consensus among the parties.

Referring to Article 26 of the Covenant of the League of Nations, Sir Fischer Williams wrote:

This proposition is of exceptional importance. It involves the proposition that the Covenant itself is not a mere agreement between independent states imposing only contractual obligations. An agreement of that merely contractual character could obviously not be amended without the assent of each individual contracting party. The Covenant is, on the contrary, a document constitutive of a permanent organization ..., and the permanency of the organization requires that its constitution should be subject to readjustment to the conditions of its life; otherwise it could not survive. For this

177. Christian Tomuschat, The Lockerbie Case Before the International Court of Justice, REV. INT'L COMM'N JURISTS, at 38, 43-44 (June 1992).

178. See Fr. CONST. art. 28. See also Letter from Thomas Jefferson to Samuel Kercheval (July 12, 1816), in THOMAS JeFFERSON: WRITINGS 1395, at 1402 (Merrill D. Peterson ed., 1984).

179. See Certain Expenses of the U.N., 1962 I.C.J. 151, 182, 185 (July 20) (Spender, J., sep. op.). 
readjustment the unanimity of the corporation is not requisite; a dissentient minority cannot veto the readjustment . . . ${ }^{180}$

While this is also true in the case of the Charter, the latter takes another major step towards constitutionalism. According to Article 26, paragraph 2 of the Covenant, an amendment did not bind a dissenting state, "but in that case it shall cease to be a Member of the League." In contrast, a U.N. member state, although opposing an amendment, is bound by it. Even by withdrawing from the organization, a state cannot escape its constitutional obligations.

\section{A "Charter"}

The drafters of the Charter styled their work a "Charter," thereby choosing a name which denotes an especially elevated class of legal instruments. In modern English law, a charter is a deed granted only by the Crown, in the form of letters patent under the Great Seal, of special powers, rights, privileges and immunities. ${ }^{181}$ On his accession to the throne, Henry I issued the "Charter of Liberties," which placed restrictions on the power of the Crown. The most famous instrument bearing the title of a Charter is the Magna Carta to which King John assented in 1215. It gained "permanent significance as the first great instance of the setting down, in writing, of limitations on the royal power."182 The British colonies in North America began their life under "Charters" granted by the King. The first enactment of the first popular assembly of New York Colony was called the "Charter of Liberties and Privileges" (1683). At the time Thomas Jefferson drafted the Declaration of Independence, the Charters were seen as guarantors of constitutional freedom. In the Declaration, the King was reproached for "taking away our Charters, abolishing our most valuable Laws, and altering fundamentally the Forms of our Governments." ${ }^{183}$ In Europe, the French Constitution of 1814 (revised in 1830) was styled Charte constitutionelle. During the Second World War, in 1941, President Roosevelt and Prime Minister Churchill chose the title "charter" when declaring the fundamentals of a postwar international order. In this "Atlantic Charter" they proclaimed, in phrases reminding of constitutional instruments, a number of rights of peoples and nations.

180. John Fischer Williams, The League of Nations and Unanimity, 19 AM. J. INT'LL. 475, 485 (1925). For the U.N. Charter, see ALF RosS, CONSTITUTION OF THE UNITED NATIONS: ANALYSIS OF STRUCTURE AND FUNCTION 35-36 (1950).

181. See David M. WALKer, The OXFord COMPANion to LaW 208 (1980).

182. Id. at 796.

183. ThE DECLARATION OF INDEPENDENCE para. 15 (U.S. 1776). 
Against the background of this history, there is no doubt that in 1945 the term "charter" was understood to be equivalent to "written constitution." 184 The U.N. founders chose this term and not, for instance, "covenant" which had been term used in the League of Nations statute. A covenant is an agreement or promise; in English biblical translations it denotes an engagement entered into by God with a person or people. A charter, on the other hand, is a document setting forth constitutional rights and responsibilities. The constitutional goals of the Charter are confirmed by the opening words of the Charter ("We the peoples of the United Nations") which are modeled on the preamble of the Constitution of the United States ("WE THE PEOPLE of the United States ..."). The drafters of the Charter phrased the text in terms of a constitution enacted by the peoples represented at San Francisco. The Covenant of the League of Nations, in contrast, opened with the classical words of a treaty: "The High Contracting Parties ..."

\section{Constitutional History}

As far as we can speak of a "constitutional history" of the international community since 1945 , it has been shaped, and taken place, in the United Nations and, in particular, in its General Assembly. It is sufficient to mention a few key words to make the reader recall the great debates which have profoundly influenced, if not changed, global life: self-determination of peoples, decolonization, human rights, fight against racial discrimination, definition of aggression, nuclear arms, utilization of outer space and the sea-bed ("common heritage of mankind"), global environmental problems, especially the use of nonrenewable resources and the protection of particularly vulnerable areas (Antarctica, tropical forests). In all these discussions, the U.N. regarded itself as the "natural forum"; and, indeed, no other body could have claimed a similar legitimacy. Further, "[p]ractically all the proposals for world constitutionalism in the postwar era have taken the U.N. Charter and its institutional arrangements as a point of departure," and not surprisingly so because "the U.N. as the premier world body is an open system in continuous interaction with the flow of global megatrends, its

184. See also I THE SHORTER OXFORD ENGLISH DICTIONARY ON HISTORICAL PRINCIPLES 294-95 (C.T. Onions ed., 1933) ("[a] written document delivered by the sovereign or legislature ... granting privileges or recognizing rights."). 
politics instantly reflecting and effecting momentum towards one or other of the competing approaches to world order." 185

\section{Universality and the Problem of Sovereignty}

An outstanding feature of the ideal type of constitution is the principle of universality or inclusiveness-a constitution applies without exception to all members of the community it purports to govern (which does, however, not imply that it has to treat them all alike). The community in question here is the entire international legal community. This includes, in particular, sovereign states regardless of their membership in the U.N.. This raises the question whether a state which has not ratified the Charter can be regarded as committed to observing it. It could now be argued that the non-members, by accepting the "basic principles" of the Charter, tacitly consented to the entire instrument because the basic principles cannot be separated from the machinery created to implement and safeguard them. This, however, would grossly distort reality. Some countries, such as Switzerland, have chosen not to become members of the U.N.. We cannot circumvent the problem merely by saying that the number of states remaining outside the organization has become small. The doctrinal weight of the issue is not lessened by this fact.

Article 34 of the Vienna Convention on the Law of Treaties states "[a] treaty does not create either obligations or rights for a third State without its consent," and this codifies a principal consequence of the sovereignty and equality of states.

It may be argued that the Charter is universal because its drafters, dismissing the established pacta tertiius non nocent rule, wanted it to be that way. Such self-authorization could be understood as part of the revolutionary grand design underlying the Charter which I have referred to above. ${ }^{186}$ However, the claim that the Charter itself lays to the allegiance of non-member states is phrased in rather cautious terms-the organization "shall ensure" that such states "act in accordance" with the principles set out in Article 2, paragraphs 1-5 of the Charter "so far as may be necessary for the maintenance of international peace and security." For this reason, I suggest it is rather a functional interpretation of the concept of sovereignty-the basis of the pacta

185. Samuel S. Kim, In Search of Global Constitutionalism, in THE CONSTITUTIONAL FoundATIONS OF WORLD PEACE 55, 57 (Richard A. Falk et al. eds., 1993) [hereinafter CONSTITUTIONAL FoundATIONS]. See also ALLOTT, supra note 1, at 319 (The U.N. "comes closest to being the general social process of a pre-social international society").

186. See supra text accompanying note 157. 
tertiis non nocent rule - which explains and legitimizes the Charter's universal application.

Today, there is general agreement that sovereignty cannot mean unlimited international freedom of action as this would be incompatible with the very idea of a legal order. Rather, the notion describes the legal status which the international community assigns to its principal members at a given point of time. "[S]overeignty of the States, as subjects of international law, is the legal authority of the States under the authority of international law." 187 The concept of sovereignty is not static. Its substance has changed and will change in the course of time.

An important innovation was introduced by Article 2(1) of the Charter which emphasizes the interdependence of sovereignty and equality ${ }^{188}$ and, what is more, gives the idea of equality precedence over that of sovereignty by relegating the latter to the position of an attributive adjective which merely modifies the noun "equality." It is "sovereign equality," not "equal sovereignty" the Charter speaks of. ${ }^{189}$ This is fully in line with the fact that the instrument significantly restricts states' traditional "sovereign rights." From the two elements, "sovereignty is in a process of progressive erosion, inasmuch as the international community places ever more constraints on the freedom of action of States." We witness a "development towards greater community discipline ... driven by a global change in the perception of how the right balance between individual State interests and interests of mankind as a whole should be established." ${ }^{190}$ Sovereignty, as a concept excluding legal superiority of any one state over another, ${ }^{191}$ is not at odds with a greater role of the international community vis-à-vis all its members. All that states can ask is to be treated equally in and before the law. ${ }^{192}$

187. Hans Kelsen, The Principle of Sovereign Equality of States as a Basis for International Organization, 53 YALE L. J. 207, 208 (1944). See also Albrecht Randelzhofer, Staatsgewalt und Souveränität, in I HANDBUCH DES STAATSRECHTS, supra note 56, at 700, and ALLOTT, supra note 1 , at 309, 418 .


COMMENTARY AND DOCUMENTS 98-99 (2d ed. 1949); and Bleckmann,, supra note 41, at 77-89.

189. It is interesting to note that the Treaty on the Final Settlement with Respect to Germany, following the terminology of the Charter, describes Germany's status as that of an "equal and sovereign partner in a united Europe," while older peace treaties simply used the word "sovereignty." Treaty on the Final Settlement with Respect to Germany, Sept. 12, 1990, para. 4, 29 I.L.M. 1186 (1990).

190. Tomuschat, supra note 68 , at 292.

191. Par in parem non habet imperium or, as the Declaration on Friendly Relations, supra note 175 , puts it, "States are juridically equal."

192. See also Henkin, supra note 42 , at 356. 
Sovereign equality depends on a comprehensive prohibition of the use of force and a working mechanism to implement and enforce it.

In principle, to set forth sovereign equality means to respect the existence and integrity of each State. However, ... far into the twentieth century the legal position did not live up to that proposition in that the use of force as the very denial of legal equality was not forbidden. With the comprehensive ban on the use of force under Article 2(4) of the U.N. Charter the system has eventually found its logical coherence. ${ }^{193}$

Thus, adherence to the Charter does not diminish, or is in conflict with, a state's sovereign equality. Rather it is a necessary prerequisite for the de facto enjoyment of that right. It is only by the Charter and the organization it has established that a state's sovereign equality can be effectively protected.

As far as non-members are concerned, if the Charter were interpreted as a treaty in favor of third states, non-member states would benefit in many ways. They would benefit from the protection granted by the Charter, its procedural guarantees, and the restrictions placed upon other states with respect to their right of self-defense. Yet nonmember status would not be subject to any obligation set out in the Charter. Nor could the Security Council lawfully take action against them. It is obvious that such a privileged position for some states would go directly against the fundamental principle of equality-a principle which is mirrored and concretized by the Charter's system of collective security. ${ }^{194}$ It follows from the concept of sovereign equality that if a state can refer to Chapter VII as a remedy against unlawful action by other states, it must also be a possible addressee of Charter VII measures when it violates the Charter.

This, in turn, challenges the opinion that non-member states, as long as they do not contravene Charter provisions, are not bound by the instrument. Either a state is bound by the Charter or it is not. Why should a non-member state, so long as it complies with the Charter, not be obliged to respect it if, in the very second it breaches the instrument, it is considered to be subject to it? Such a view is illogical. In a system characterized by the rule of law, one can only be held responsible for an

193. Tomuschat, supra note 68 , at 293. See also id. at $221-22,334,355$.

194. In the Charter, "rights and benefits" and "obligations" generally have a complementary character. U.N. CHARTER art. 2, para. 2. Only states that are able and willing to carry out the obligations can become members of the organization and enjoy the respective rights. See id. art. 4, para. 1. A member against which preventive or enforcement action has been taken by the Security Council may be suspended from the exercise of the rights and privileges of membership. See id. art. 5. See also id. art. 6. 
action if that person was subject to the rules in question at the time the action was taken. As Professor Kelsen said, "[i]f the Charter attaches a sanction to a certain behaviour of non-Members, it establishes a true obligation of non-Members to observe the contrary behaviour."195

Article 2(6) of the Charter supports Kelsen's view. The pacta tertiis non nocent rule itself is based on the principle of sovereign equality which calls for this very exception. It is not by virtue of Article $2(6)$ that the Charter is binding on non-member states. Rather the Charter is binding because of the overriding principle of sovereign equality. Accordingly, non-member states are not only bound by the principles of Article 2, but the Charter as a whole. This means that binding decisions of the Security Council can be addressed to a nonmember state-be it a law-breaker or a state expected to assist the U.N. in the performance of preventive or enforcement action. Equally, the priority of the Charter over conflicting obligations (Article 103) applies to members and non-members alike.

The criterion of universal application of the Charter therefore met. I conclude that a comparison of the Charter with the ideal type of constitution reveals a similarity sufficiently strong to attribute constitutional quality to the instrument.

Good arguments support the view that the Charter has had constitutional quality $a b$ initio. In the words of the Australian delegate to the last Assembly of the League of Nations in April 1946: "Des bouleversements causés par deux guerres mondiales a surgi l'une des créations les plus caractéristiques du $\mathrm{xx}^{\mathrm{e}}$ siècle: l'organisation d'une communauté internationale régie par une constitution écrite." ${ }^{196}$ But at any rate, during the fifty years of U.N. history, a constitutional predisposition of the Charter has been confirmed and strengthened in such a way that today we can rightly call it a constitution. Indeed, "international law can now properly be regarded as "law with a constitution." 197 The international community is a constitutional community or "une communauté normative par le droit constitutionnel."198

195. KELSEN, supra note 157 , at 107.

196. Address by Professor K.H. Bailey, reprinted in L'HÉRITAGE DE LA SOCIÉTÉ DES NATIONS 53 (Secrétariat de la Société des Nations ed., 1946).

197. See Sir Humphrey Waldock, General Course on Public International Law, 106 REC. DES CouRs 1, 7 (1962-II). See also id. at 36, 38; Ross, supra note 180, at 36 ("in a systematic respect the Charter is a constitution"); and R. St. J. Macdonald, Reflections on the Charter of the United Nations, in FESTSCHRIFT FÜR KARL JOSEF PARTSCH ZUM 75. GEBURTSTAG 29, 45 (Jürgen Jekewitz et al. eds., 1989).

198. See RENÉ-JEAN DUPUY, LA COMMUNAUTÉ INTERNATIONALE ENTRE LE MYTHE ET L'HISTOIRE 151 (1986) (speaking of "[l]a communauté normative par le jus cogens."). 


\section{CONCEPTUAL DISTINCTIONS}

All the norms of the Charter share a constitutional quality. For their implementation, the substantive rules depend on the rules of procedure, and the rules of procedure are meaningless without material norms. The inclusion of rules of procedure and organization in the circle of constitutional norms of the international community is a particularly tangible consequence of the view presented here. One could not arrive at this result if constitutional principles were grounded solely on customary law.

\section{A. Constitutional Law and "General International Law"}

What is the relationship between "general international law" and the law of the Charter? Following Professors Verdross and Simma, I suggest that the Charter, as constitution of the international legal community, embraces all international law. "The Covenant [of the League of Nations]," Professor Waldock wrote, "was conceived of rather as a multilateral treaty operating within the framework of international law than as the constitution of an international political society within which international law would operate." ${ }^{199}$ In the case of the Charter, exactly the opposite is true. Accordingly, there is no room for a category of "general international law" existing independently beside the Charter. Instead, the Charter is the supporting frame of all international law and, at the same time, the highest layer in a hierarchy of norms of international law.

The drafters of the Charter assumed the validity of certain legal rules, in particular those regarding the conclusion and entry into force of treaties, which do not appear in the text of the Charter. Should one declare such rules to have been "incorporated" by the Charter, or should one rather see them as a body of customary law of the international community the Charter has tacitly approved of? Either answer presumes the fact that the community of states which enacted the Charter had the authority partly or completely to repeal the then existing law, and that pre-1945 law could not remain in force without the Charter acting as an intermediate. In that sense too, the Charter connects the by-gone era and the new.

One should distinguish norms of constitutional character from general rules which are not to be accorded that quality. In the case of

199. Waldock, supra note 197, at 19. 
the former, to which primordial (or, in Professor H.L.A. Hart's language, secondary) rules like pacta sunt servanda belong, one should speak of "incorporation" because the essential unity of the constitutional order devised in 1945 is thereby emphasized. Rules belonging to the latter group, such as customary rules of the law of the sea, may better be referred to as customary international law upheld by the Charter.

The same distinction between international constitutional law and other norms of international law applies to treaty law tacitly confirmed by the Charter in 1945. Pre-1945 contractual rules of a constitutional character, for instance the renunciation of war as an instrument of national policy in the 1928 Kellogg-Briand Pact, have generally been formally adopted and modified by the Charter. Accordingly, there is no need to speak of informal incorporation. On the other hand, the bulk of treaty law upheld by the Charter, such as the 1907 Hague Convention Respecting the Laws and Customs of War on Land, has the rank of ordinary law.

During the life of the Charter, constitutional rules which preceded the instrument have become a part of it, and they are subject to the relevant rules of interpretation and amendment, the practice of the U.N. organs, etc. They are valid solely in the form the Charter has given them. Neither can new customary law come into being which would amend, or derogate from, Charter law. This already follows from Article 103 of the Charter which can only been read to give the Charter priority over all conflicting obligations of states regardless of their formal source. For this reason, there is no parallel existence of customary constitutional rules and Charter rules. The United States Government was right when it argued in the Nicaragua case that "the provisions of the United Nations Charter ... subsume and supervene related principles of customary and general international law."200 Indeed, "the existence of principles in the United Nations Charter precludes the possibility that similar rules might exist independently in customary international law."201

As is well known, the Court rejected this argument, holding that "even if two norms belonging to two sources of international law appear identical in content, and even if the States in question are bound by these rules both on the level of treaty-law and on that of customary international law, these norms retain a separate existence." ${ }^{202}$ The Court's remarks are certainly correct in so far as the general relationship

200. Nicaragua, 1986 I.C.J. 14, at 93, para. 173.

201. Id. at 93 , para. 174 (summarizing the U.S. view) (emphasis added).

202. Id. at 95 , para. 178 (emphasis added). 
between norms belonging to different categories of sources of international law is concerned. But they overlook the special case of constitutional rules expressly or implicitly codified in the Charter. ${ }^{203}$ The Court went so far as to claim that "the Charter gave an expression ... to principles already present in customary international law, and that law has in the subsequent four decades developed under the influence of the Charter, to such an extent that a number of rules contained in the Charter have acquired a status independent of it." ${ }^{204}$ How shall law expressly adopted by the Charter, and developed under its influence, "acquire" an independent status? As Judge Weeramantry said in his dissenting opinion in the Lockerbie case, "[t]he entire law of the United Nations has been built up around the notion of peace and the prevention of conflict." 205 Regrettably, the Court, by suggesting that there is "a rule (or set of rules) [regarding the non-use of force] to be henceforth treated separately from the provisions, especially those of an institutional kind, to which it is subject on the treaty-law plane of the Charter," ${ }^{206}$ rather impaired the unity of the legal order that the Charter had sought to establish in that field. ${ }^{207}$

If the Charter, despite its claim to last eternally, were to lose legal force, it would remain to be seen whether it would be replaced by a new constitution, or whether international law would return to its preconstitutional state. At any rate, the continuity of the legal order would be interrupted. Even if rules presently being in force "remained" valid, their contents, the reason for their validity, would remain the same. If there were a new constitution, it could give validity to the norms in question; otherwise, the validity of these norms would depend on their

203. The Court's reasoning was clearly guided by its wish to adjudicate the dispute in spite of the U.S. multilateral treaty reservation. From a constitutional point of view, however, a reservation excluding jurisdiction over constitutional law of the international community cannot be regarded as admissible because it would prevent the Court from applying the very core principles that community is based on.

204. Nicaragua, 1986 I.C.J. 96-97, para. 181.

205. 1992 I.C.J. 70, 180.

206. Nicaragua, 1986 I.C.J. 99-100.

207. For a criticism of the unpredictability of the applicable law resulting from the Court's approach, see Shabtai Rosenne, The Role of the International Court of Justice in Inter-State Relations Today, 20 REVUE BELGE DE DROIT INTERNATIONAL 275, 284 (1987).

As regards Article 51 of the Charter, the provision in question, the Court conceded that "the present content" of the "inherent" right of self-defense "has been confirmed and influenced by the Charter." Nicaragua, 1986 I.C.J.94, para. 176. This qualification considerably limits the "separate existence" claim quoted in the text.

For a discussion of a possible customary right of self-defense, see laN BROWNLIE, INTERNATIONAL LAW AND THE USE OF FORCE BY STATES 269-75, 279-80 (1963); Brun-Otto Bryde, Self-Defence, in ENCYCL. PUB. INT'L L., Instalm. 4, 212, 214 (1982); YORAM DINSTEIN, WAR, AGGRESSION AND SELF-DEFENCE 182-83, 252 (2d ed. 1994). 
having been newly accepted by the members of the international community. ${ }^{208}$

\section{B. "Constitutional By-Laws" of the International Community}

Attributing constitutional quality to the Charter does not imply that other international agreements concluded after 1945 cannot be of constitutional rank too. Nor does it rule out the possibility of post-1945 constitutional prescriptions existing in the form of customary law or general principles of law. For instance, "world order treaties" like the two Human Rights Covenants or the Genocide Convention are part of the constitutional foundation of the international community. However, we need to perform a closer examination along the lines of my analysis of the Charter to ascertain the exact status of their provisions within the framework of international constitutional law. Tentatively, I suggest that these treaty and customary rules can be ascribed constitutional quality if, and to the extent that, they characterize in detail, or further develop, the constitutional law of the Charter. One could speak of "constitutional by-laws" of the international community because it is law of an accessory nature, adding to, and implementing objectives of, the law of the Charter. It is also possible to use the notion of a substantive constitution (as opposed to a formal or written one) to describe that larger segment of a community's legal order which encompasses its key rules.

From this it appears, first, that a repeal of Charter provisions by such later by-laws is impossible. The rules in question would only pretend to constitutional quality; because of Article 103 of the Charter, the law of the Charter would prevail. Second, there cannot be constitutional treaty or customary law supplementing the Charter in areas where the Charter has set out comprehensive rules that leave no room for additional prescriptions. Here, Articles 108 and 109 of the Charter represent the only way to introduce constitutional change beyond the range of interpretation. Such areas include the functions and powers of the various organs established by the Charter. Even silence of the Charter on a certain point may reflect a (negative) decision rather than permission freely to regulate the question elsewhere.

The concept of "constitutional by-laws" rather than the concept of "incorporation" may better describe the relationship of certain fundamental prescriptions developed since 1945 with the Charter than that of

208. See KELSEN, supra note 5, at 117-18.

HeinOnline --- 36 Colum. J. Transnat 588 (1998) 
"incorporation." Although the notion of incorporation explains well what happened to general international law in 1945 , one can hardly say that since 1945 an incessant and indefinite process of incorporation is taking place before our eyes. Such terminology would rather obscure than illuminate the phenomenon of key rules agreed upon after 1945 that were not included in the text of the Charter.

\section{Constitutional Law, Jus Cogens, and Obligations Erga Omnes}

The realms of international constitutional law and jus cogens are only partially identical. The differences are result from the different origins and objectives of the two concepts. Constitutional law can be described as the common denominator of the international community. It is the body of rules and principles defining, in form and in substance, the basis of the international community, and indicating the general course the community has decided to steer. The constitution of the international community, as embodied in the United Nations Charter, has a substantive part, in which common values, goals and principles are set out, and a part relating to organization and procedure which establishes the machinery necessary for carrying out the substantive norms. It follows from their very nature that these rules can only be amended by the constitutional community as such. ${ }^{209}$

Jus cogens, on the other hand, has been defined as a body of norms "accepted and recognized by the international community of States as a whole ... from which no derogation is permitted and which can be modified only by subsequent norm[s] of general international law having the same character."210 This category of peremptory norms places a set of rules beyond the reach of states when they, bilaterally or multilaterally, exercise their law-making function. As such, its potential scope is wider than that of constitutional law. Theoretically, any rule, not only a rule concerning the constitutional structure of the international community, can be made a peremptory norm. However, at present the number of rules that undisputedly have that quality of a peremptory norm is much smaller than that of constitutional rules. But there is a partial overlap between jus cogens and constitutional law which has often obscured the difference between the categories. The

209. See infra text accompanying note 246 et seq.

210. Vienna Convention on the Law of Treaties, opened for signature May 23, 1969, art. 53, 1155 U.N.T.S. 331. For an instructive overview of the concept of jus cogens, see PAUL REUTER, INTRODUCTION TO THE LAW OF TREATIES 142-46 (José Mico \& Peter Haggenmacher eds., 1995). 
prohibitions of genocide, aggression, slavery and of trading in human beings, as well as the right of peoples to self-determination belong to both classes of norms. Other constitutional rules, like provisions on organization and procedure, are not peremptory norms as defined by Article 53 of the Vienna Convention. They are, however, similarly placed out of the reach of states in that they can only be amended following the procedure set out in Articles 108 and 109 of the Charter. It is, therefore, not the lack of capacity to commit the international community as a whole which accounts for the fact that these procedural constitutional rules are not peremptory norms, as conceived by the Vienna Convention. Rather the quality of these rules arises out of the specific purpose of jus cogens in comparison with that of constitutional law. According to Article 53 of the Vienna Convention and Article 103 of the Charter, a breach of a rule of jus cogens or constitutional law leads to the same result, namely the invalidity of the relevant agreement according to Article 64 of the Vienna Convention. If a new norm of jus cogens emerges, any existing treaty which is in conflict with that norm becomes void. So too, an obligation newly introduced into the Charter by way of amendment would prevail over any conflicting obligation or, as has become clear in the Lockerbie case, right of a state. At the same time, either a peremptory or a constitutional norm bar the development of a contravening rule of customary law.

Recently, Professor E. Lauterpacht, acting as an ad hoc judge of the I.C.J., addressed the question of a possible collision of the priority status of Charter obligations according to Article 103 with norms of $j u s$ cogens:

[T] he prohibition of genocide, unlike the matters covered by the Montreal Convention in the Lockerbie case to which the terms of Article 103 could be directly applied, has generally been accepted as having the status not of an ordinary rule of international law but of jus cogens .... The relief which Article 103 of the Charter may give the Security Council in case of conflict between one of its decisions and an operative treaty obligation cannot-as a matter of simple hierarchy of norms-extend to a conflict between a Security Council resolution and jus cogens. ${ }^{211}$

According to Article 103, however, obligations of states arising from decisions of the Security Council only lawfully arise "under the

211. Application of the Convention on the Prevention and Punishment of the Crime of Genocide (Bosnia \& Herzegovina v. Yugo. (Serbia \& Montenegro)), 1993 I.C.J. 407, at 440, para. 100 (Sept. 13) (Lauterpacht, J., sep. op.). 
present Charter" if they are in accordance with the constitutional law of the international community, including the peremptory norms referred to above. It is only decisions consistent with jus cogens that can create obligations under Article $103 .^{212}$ Given the nature and function of jus cogens, this symmetry between peremptory norms and constitutional obligations arising under the Charter is likely to persist in the case of the creation of new jus cogens rules.

There is also a partial identity of constitutional law and obligations erga omnes. It is well known that the I.C.J. has identified various obligations "towards the international community as a whole." include the prohibitions of acts of aggression, and genocide, and the duties of states concerning the basic rights of the human person, including protection from slavery and racial discrimination. The first of these prohibitions is directly pronounced in the Charter (Article 2(4)); the others are based on the Charter ${ }^{214}$ and have been elaborated in treaties which have the character of "constitutional by-laws" of the international community. In its recent judgment in the East Timor case, the Court added the right of peoples to self-determination to its list of norms possessing erga omnes character. ${ }^{215}$ The principle was already referred to in the Charter ${ }^{216}$ and was defined as a right in Article 1 of the two International Human Rights Covenants of 1966. In principle every constitutional rule has an erga omnes effect in the sense that it is directed towards, and binding on, all members of the community, and that all members have a legal interest in its observance by all other members. ${ }^{217}$ But the specific obligations that are currently recognized as obligations erga omnes represent a subset of international constitutional law.

Given that the most characteristic feature of these obligations is this relation to community values and interests - this is not astonish-

212. See Lockerbie, 1992 I.C.J. 64, 174 (Weeramantry, J., dissenting) ("The powers of the Council are subject to Articles 1 and 2 and, in particular, to the guarantees they provide of conformity with international law"), Oscar Schachter, The UN Legal Order: An Overview, in 1 UNITED NATIONS LEGAL ORDER 1, 13 (Oscar Schachter \& Christopher C. Joyner eds., 1995). See also Lockerbie, 1992 I.C.J. 101-02, 206-07, para. 23 (El-Kosheri, J., dissenting) ("[T]he meaning of Article 25 is that the Members are obliged to carry out only those decisions which the Security Council has taken in accordance with the Charter" (quoting KELSEN, supra note 157, at 95)). Cf. Gowlland-Debbas, supra note 176, at 667.

213. Barcelona Traction, 1970 I.C.J. 3, 32, paras. 33-34.

214. See U.N. ChARTER pmbl. and arts. 1(3), 13(1b), 55, 62(2), 68, 76.

215. See East Timor (Port. v. Austl.), 1995 I.C.J. 90, 102, para. 29 (June 30).

216. See arts. 1(2) and 55. See also arts. 73 and 76.

217. See Weller, supra note 8 , at 52. 
ing. ${ }^{218}$ The category of obligations erga omnes was advanced to give states who, according to traditional international law, were not affected by a breach of rules, "a legal interest in their protection." ${ }^{19}$ This way, pivotal community values could be safeguarded in the absence of community organs. As Judge Ago remarked, the international community is envisaged as having a right to react to such serious forms of internationally wrongful acts. ${ }^{220}$ Recognizing the constitutional character of the Charter, which implies the existence of effective organs of the international community, profoundly changes that picture. ${ }^{221}$ It cannot now be held only in an abstract way that obligations "are owed to the community." The existence of community organs allows us to speak of an organized entity possessing a right, and the actual ability, to demand the performance of obligations erga omnes. ${ }^{222}$ However, for the time being the individual states have still a role to play in ensuring compliance with the rules in question. At present, only the prohibition of aggression and, arguably, grave and wide-ranging violations of human rights, can be enforced by a community organ. ${ }^{223}$ Since the U.N. lacks standing before the I.C.J., it is also prevented from judicially charging a state with a violation of obligations erga omnes. To that extent states perform, in an ancillary capacity, functions of community organs; they act as agents of the international community "in the public interest."224

218. This feature led Professor Delbrück to aptly describe them as "public interest norms." See Jost Delbrück, Comments, in ALLOCATION OFLAW ENFORCEMENT AUTHORITY, supra note 125, at 174, 194.

219. Barcelona Traction, 1970 I.C.J. 32, para. 33.

220. See Roberto Ago, Obligations Erga Omnes and the International Community, in INTERNATIONAL CRIMES OF STATES: A CRITICAL ANALYSIS OFTHE ILC'S DRAFT ARTICLE 19 ON STATE RESPONSIBILITY 237, 238 (Joseph H.H. Weiler et al. eds., 1989). For discussion, see ANDRÉ DE HOOGH, OBLIGATIONS ERGA OMNES AND INTERNATIONAL CRIMES: A THEORETICAL INQUIRY INTO THE IMPLEMENTATION AND ENFORCEMENT OF THE INTERNATIONAL RESPONSIBILITY OF STATES 93-95 (1996).

221. For a specific reference to "the organized international community," see South West Africa (Eth. v. S. Afr.; Liber. v. S. Afr.), 1966 I.C.J. 6, 467 (July 18) (Padilla Nervo, J., dissenting).

222. Though based on an assessment of specific legal interests of the U.N., the same conclusion is arrived at by DE HOOGH, supra note 220 , at 114-27.

223. U.N. CHARTER art. 39.

224. See Jost Delbrück, The Impact of the Allocation of International Law Enforcement Authority on the International Legal Order, in ALLOCATION OF LAW ENFORCEMENT AUTHORTY, supra note 125 , at 135,154 . For a discussion of the respective role of the Security Council, see also Torsten Stein, Decentralized International Law Enforcement: The Changing Role of the State as Law Enforcement Agent, in id. at 107, 114-19, and the comment by Tomuschat, id. at 159-60. See also ALLOTT, supra note 1, at 309-10, 418 (describing states as constitutional organs of international society). For an early expression of the principal-agent idea, see HANS KelSEN, PRINCIPLES OF INTERNATIONAL LAw 25 (1952) ("The state which, authorized by international law . . ., resorts to reprisals may be considered to be acting as an organ of the international community constituted by international law. The enforcement action 
At any rate, the category of obligations erga omnes appears to be an interim phenomenon in the process of constitutionalization of the international community. The community has already been recognized to respect many rights, without being able to enforce them. In a constitutional community equipped with its own organs, the term obligations erga communitatem will replace a notion which emphasized the individual states' authority to react to a violation of community values.

\section{CONSEQUENCES}

The question arises whether it is possible to deduce from the constitutional character of the Charter any more specific consequences. I suggest that the perception of an instrument as constitution gives it a certain shape and contour, and that seeing an instrument in its proper constitutional perspective allows us to answer certain questions.

\section{A. Non-Member States}

Seeing the Charter as a constitution offers the best possible explanation for the demands made on non-member states in Articles $2(6)$ and 103. As Hans Kelsen already remarked in 1950, "[o]nly if the Charter ... is considered to constitute a new general international law, that is to say, if the law of the United Nations is recognized to be valid for, and applicable to, all the states of the world, the provision of Article 103 as relating to treaties between Members and non-members is not at variance with existing law." 225 It is true that the two provisions "are merely partial answers to the fundamental issue of the place of the U.N. Charter in the international community and its relationship to other

may be interpreted as an action of this community, its reaction against a violation of international law.").

The regime of consequences of an international crime envisaged by the I.L.C. in its draft articles on state responsibility is guided by the view that "apart from any collective response of States through the organized international community ... a ... response to a crime is called for on the part of all States," to which therefore "injured State" status is attributed. Report of the International Law Commission, U.N. GAOR, Supp. No. 10, U.N. Doc. A/51/10, 121, at 170 (1996) (draft article 40(3)). See also Frowein, supra note 42, at 405-22, and Tomuschat, supra note 68 , at 365-67.

225. KELSEN, supra note 157, at 116. That it is not possible consistently to explain, on the basis of a contractual view, the status of non-member states under the Charter was demonstrated by Professor Macdonald in a review of the relevant literature. See Macdonald, supra note 197. 
norms of international law."226 Nevertheless, they give a strong hint of its constitutional character. Such qualification also explains the corresponding practices of the Security Council both of taking action against such states on the basis of Chapter VII and of directing, for almost twenty years now, its decisions to "all States."227

\section{B. The Charter as a Living Instrument}

In general, the life of the Charter can well be explained in terms of the constitutional model. Referring to the Charter, an early commentator opined that "[c]onstitutions always have to be interpreted and applied, and in the process they are overlaid with precedents and conventions which change them after a time into something very different from what anyone, with only the original text before him, could possibly have foreseen." 228 Recently, the U.N. was called "an entire system which is in constant movement, not unlike a national constitution whose original texture will be unavoidably modified by thick layers of political practice and jurisprudence."229 By way of example, one might mention the Uniting for Peace resolution of 1950 , the codification and development of Charter principles and rules by the General Assembly, ${ }^{230}$ the invention of peacekeeping operations, the good offices function performed by the Secretary-General, the expansion of the concept of international peace and security in the practice of the Security Council, and the development of procedures of monitoring the observation of human rights by states. This is not to say that any deviation from the text of the Charter can be justified by calling the

226. Köck, supra note 42 , at 92.

227. See Tomuschat, supra note 68 , at 256 . Some scholars opine that the Council, when taking action against non-member states, does so as an organ of an alliance of states pursuing their right of collective self-defense. See VERDROSS \& SIMMA (3d ed.), supra note 41, at 177, and Tomuschat, supra note 68 , at 253 . This proposition finds no support in the practice of the Security Council-and gladly so because the Council cannot divest itself of its quality as an organ of the international community, and as such it can only take enforcement action on the basis of Chapter VII of the Charter.

228. J.L. Brierly, The Covenant and the Charter, 23 BRIT. Y.B. INT'L L. 83 (1946).

229. Tomuschat, supra note 68 , at 251-52.

230. See, e.g., Universal Declaration of Human Rights, G.A. Res. 217A, U.N. GAOR, 3d Sess., U.N. Doc. A/810 (1948); Declaration on the Granting of Independence to Colonial Countries and Peoples, G.A. Res. 1514, U.N. GAOR, 15th Sess., Supp. No. 16, U.N. Doc. A/4684 (1960); Declaration on Friendly Relations, supra note 175; Charter of Economic Rights and Duties of States, G.A. Res. 3281, U.N. GAOR, 29th Sess., Supp. No. 31, U.N. Doc. A/RES/3281 (1974); Definition of Aggression, G.A. Res. 3314, U.N. GAOR, 29th Sess., Supp. No. 31, U.N. Doc. A/9631 (1974). 
instrument a constitution. ${ }^{231}$ Nor is it suggested that all of the developments mentioned above have taken place in accordance with the Charter. Only a thorough review of each particular modification could prove its constitutionality or unconstitutionality.

As it is a general principle of any constitutional system of governance that the exercise of power shall be guided and confined by law, a constitutional view of the Charter requires adequate mechanisms to ensure the constitutionality of the conduct of the organs established under the Charter. ${ }^{232}$

\section{Constitutional Interpretation}

A constitution, I argue, typically emancipates itself from the forces that brought it about. To use Judge Alvarez' wonderful metaphor, constitutions "can be compared to ships which leave the yards in which they have been built, and sail away independently, no longer attached to the dockyard." ${ }^{233}$ Hence, an interpretation based on the original will of the parties ("static-subjective interpretation") is inappropriate. Such an approach would unduly subject the present and the future to whatever a bygone generation declared to be the law, and this would impede the solution of contemporary problems. Instead, an interpretation of a Charter provision must aim to establish, at the time of interpretation, the objective meaning. It should, in light of the concrete circumstances of the case in question, take account of the dynamic character and inherent incompleteness of any constitution ("dynamic-evolutionary" or “objective interpretation"). ${ }^{234}$

231. For a sharp criticism of several practices which the author regards as violations of the Charter and of "the constitutional foundations on which the Charter . . . [is] based," see YeHUdA Z. BluM, ERODING THE UNTTED NATIONS ChARTER 6 (1993). See also Leo Gross, On the Degradation of the Constitutional Environment of the United Nations, 77 AM. J.INT'L L. 569 (1983) (criticizing the practice of "[m]anipulating [the U.N. Charter] in order selectively to punish unpopular member states").

232. For an analysis of the existing means of constitutional control, in particular the role of the International Court of Justice, and possible new methods and procedures, see my forthcoming book, supra note *, ch. 10, sec. II E.

233. Reservations to the Genocide Convention, 1951 I.C.J. 15, 53 (May 28) (Alvarez, J., dissenting). See also Competence of Assembly Regarding Admission to the U.N., 1950 I.C.J. 4, 18 (March 3) (Alvarez, J., dissenting) [hereinafter Competence of Assembly] and Admission of a State to the United Nations, 1947-48 I.C.J. 57, 68 (May 28) (Alvarez, J., indiv. op.). See also DuPUY, supra note 198, at 81.

234. See Legal Consequences for States of the Continued Pesence of South Africa in Namibia (Southwest Africa) Notwithstanding Security Resolution 276, 1971 I.C.J. 16, 31, para. 53 (June 21); and South West Africa Cases (Eth. v. S. Afr., Liber. v. S. Afr.), 1966 I.C.J. 6, 325, 439 (July 18) (Jessup, J., dissenting). See also Ress, supra note 42, at 35-37. 
Accordingly, the travaux préparatoires will only be considered in exceptional circumstances. ${ }^{235}$ Besides the linguistic-grammatical and the systematic interpretation (the latter determining the place of a provision "in the general structure and scheme of the Charter)" ${ }^{236}$ teleological interpretation is of special significance. It gives weight to the object and purpose of a particular Charter rule and the Charter as a whole. It is through teleological interpretation of constituent treaties of international organizations that implied powers are established. ${ }^{237}$ Determining the powers that complete or supplement those expressly defined in the Charter is an indispensable method of constitutional development. Nevertheless, it has to be practiced with caution. Notwithstanding the growth of the welfare state in the twentieth century and the corresponding expansion of governmental rights of intervention in the private sphere of citizens, the idea of "limited government" is still inherent in the notion of constitution. The Tenth Amendment to the U.S. Constitution provides that the powers not vested in the Federal government are retained by the states or the people. In a similar way, the states constituting the international community have only bestowed a limited number of rights and responsibilities on that body. ${ }^{238}$

Of course "[t]he rule of interpretation according to which limitations of a party's sovereignty are not to be presumed already faces extensive restrictions . . . in the case of international organizations." 239 This assumption is in line with the increasingly weak condition of the notion of sovereignty that I noted above. It is not so much the principle of sovereignty of states but constitutionalism which requires us to recognize that the U.N. has only been furnished with a limited number of rights and responsibilities. Only in highly exceptional cases, in which the performance of the organization's most essential tasks is at stake, can one have recourse to the category of implied powers. In the normal life of the international community, it is up to its members to amend the

235. See also Certain Expenses of the U.N., 1962 I.C.J. 151, 182, 184-85 (July 20) (Spender, J., sep. op.). Professor Rosenne described the "lack of interest in the intentions of the original members with corresponding disinterest in the travaux préparatoires" as a characteristic element of a "constitutionalist" Charter interpretation. See ROSENNE, supra note 28 , at 237.

236. Certain Expenses of the U.N., 1962 I.C.J. at 162; see also id. at 167.

237. For the implied powers doctrine, see Reparation for Injuries Suffered in the Service of the United Nations, 1949 I.C.J. 174, 182 (Apr. 11). See also Effect of Awards of Compensation, 1954 I.C.J. 47, 56 (July 13); id. at 76, 80-81 (Hackworth, J., dissenting); Certain Expenses of the U. N., 1962 I.C.J. at 167; and id. at 198, 208, 213 (Fitzmaurice, J., sep. op.).

238. See Certain Expenses of the U.N., 1962 I.C.J. Rep. 168.

239. Ress, supra note 42 , at 27. 
Charter in order to provide the community organs with the powers deemed necessary for the accomplishment of their tasks.

The international legal community is made up of all subjects of international law-sovereign states, states enjoying a limited international legal personality, intergovernmental organizations, peoples and minorities, belligerent parties, individuals, as well as special entities like the Holy See. This is what Judge Mosler calls the "international legal community in its wider meaning"-it includes everybody "endowed with the capacity to take part in international legal relations." 240 All these legal persons are entitled to participate in the interpretation of the Charter; they constitute the respective "interpretive community."241 As long as sovereign states are in possession of the most substantial rights conferred by the international legal order, their views are particularly momentous. Nevertheless, the opinions of other community members are significant for the interpretation of rules which affect them in a special way. Human rights, for instance, cannot be properly interpreted without taking due account of the views of individuals and their nongovernmental organizations.

The interpretive method outlined here leaves ample room for constitutional adaptation. In both treaty and constitutional law, this century has seen an advance of the dynamic-evolutionary method of interpretation over the once undisputed static or textual approach. This has resulted in a convergence of prevailing methods of treaty and constitutional interpretation. If "treaty" is replaced with "Charter," Article 31(1) of the Vienna Convention on the Law of Treaties correctly describes the technique to be followed: "The Charter shall be interpreted in good faith in accordance with the ordinary meaning to be given to the terms of the Charter in their context and in the light of its object and purpose."

However, stating that Article 31(1) applies to the interpretation of the Charter is not to say that the same is true for the other paragraphs of Article 31. As a constitution, the Charter has acquired a life of its own.

240. Mosler, supra note 58, at 1252. For the view of the New Haven School, which rejects the "technical conception of the 'subjects of international law" and insists on a "comprehensive description of the participants in the world power process," see McDougal, supra note 50, at 160-62.

241. For a general description of this notion, see Detlev F. Vagts, Treaty Interpretation and the New American Ways of Law Reading, 4 EUR. J. INT'L L. 472, 480-81 (1993). See also Peter Häberle, Die offene Gesellschaft der Verfassungsinterpreten: Ein Beitrag zur pluralistischen und "prozessualen" Verfassungsinterpretation, 30 JURISTENZEITUNG 297, 299 (1975), reprinted in HÄBERLE, supra note 92, at 155, 157 ("Everybody living under conditions governed by a rule is, directly or indirectly, an interpreter of that rule .... All parts and powers of a political community may and do interpret its constitution."). 
"[Its] purpose constitutes an element of such a predominant weight for interpretation that the will of the parties becomes secondary."242 Interpretation is a task of the international community at large, but since the Charter is mainly interpreted in the day-to-day process of its application, the relevant work of U.N. organs carries special weight. ${ }^{243}$ The community has established these organs and entrusted them with the task of applying the provisions of the Charter. With this responsibility, they inevitably derive the power of interpretation. ${ }^{244}$ This interpretation, which must consider the views of all members of the international community, is not "authoritative" or "authentic" in the sense that it cannot be challenged. It can, of course, be right or wrong, and the community must strive to correct a wrong interpretive decision by making use of the respective - presently rather limited-constitutional means. From this it follows that interpretation engaged in by U.N. organs is not based on "agreement" or "consensus of all member states," or at least "the member states "concerned," in the way Article 31(3b) of the Vienna Convention speaks of "subsequent practice in the application of the treaty which establishes the agreement of the parties regarding its interpretation." Rather, the practice of the U.N. organs has gained significance for the interpretation of the Charter because of their status in the constitutional framework of the international community. The I.C.J. shared this view when it held that " $[t]$ he organs to which Article 4 entrusts the judgment of the Organization ... have consistently interpreted the text ...2245 This refers to the organs of the U.N. not its member states.

\section{Constitutional Amendment}

Every constitution presents the difficult problem of distinguishing interpretation and adaptation, progressive development and amendment. All these are different forms, or degrees, of constitutional change. While it is evident that every "living document" experiences change and must, to some extent, embrace it in order not to become irrelevant to the present, a constitution nevertheless has to channel and limit the process

242. Ress, supra note 42 , at 27.

243. See Report of Subcommittee B of Committee IV/2 of the San Francisco Conference, June 2, 1945, reprinted in THE UNITED NATIONS CONFERENCE ON INTERNATIONAL ORGANIZATION: SELECTED DOCUMENTS 879-80 (U.S. Department of State ed., 1946) [hereinafter U.N. CONFERENCE]. See also Louis B. Sohn, The UN System as Authoritative Interpreter of Its Law, in 1 UNITED NATIONS LEGAL ORDER, supra note 212, at 171-74.

244. See Competence of Assembly, 1950 I.C.J. at 15.

245. Id. at 9 . 
of transformation. It is one of the main purposes of a written constitution to ensure a higher degree of certainty within the law than that prevailing in a system of customary rules. The international community, in particular, with its complicated history, heterogeneous subjects and many actors can benefit enormously from an instrument clearly setting out the rights and duties of its members.

Do Articles 108 and 109 of the U.N. Charter set up an exclusive régime for Charter amendments so that the Charter can only be amended in the ways provided therein? The text of the provisions supports such a view. Article 108 begins with the words "Amendments to the present Charter shall come into force...." and Article 109, paragraph 2 provides that "[a]ny alteration of the present Charter ... shall take effect when ...." This leaves no room for other procedures of Charter amendment. The clauses were "supposed to reconcile the conflicting demands of flexibility and stability,"246 and there is no indication that the founding members, in particular the major powers, were prepared to relativize the effect of a compromise whose achievement had been difficult enough.

Because of the antagonism between East and West, which made it extremely difficult to comply with the requirements set out in Articles 108 and 109, however, member states eventually applied to the Charter the general rule of treaty amendment which Article 39 of the Vienna Convention phrased as follows: "A treaty may be amended by agreement between the parties" - that is, also by tacit agreement or a customary rule resulting from corresponding opinio juris and general state practice. The I.C.J. approved of this concept of informal Charter modification in its 1971 advisory opinion on Namibia when it held that the practice according to which, contrary to the wording of Article 27, paragraph 3 of the Charter, abstention or absence on the part of one of the permanent members does not hinder the adoption of a Security Council resolution "has been generally accepted by Members of the United Nations."247

246. Wolfram Karl \& Bernd Mützelburg, Comment on Art. 108, in THE CHARTER OF THE U.N., supra note 41 , at $1163,1165$.

247. Legal Consequences for States of the Continued Presence of South Africa in Namibia (Southwest Africa) Notwithstanding Security Resolution 276, 1971 I.C.J. 16, 22, para. 22 (June 21). But see Certain Expenses of the U.N., 1962 I.C.J. at 182, 191 (Spender, J., sep. op.) ("[Subsequent conduct by all parties to a multilateral treaty] may . . provide evidence from which to infer a new agreement with new rights and obligations between the parties, in effect superimposed or based upon the text of the treaty and amending the same. This latter aspect of subsequent conduct is irrelevant for present consideration since no amendment of the Charter my occur except pursuant to Article 108 of the Charter."). 
To license informal amendments, however, is to generate a grey area in which the border between law and no-more-law, and law and not-yet-law becomes blurred. Articles 108 and 109 of the Charter, which are modeled on similar provisions of national constitutions, ${ }^{248}$ set out precise procedures for amending the Charter. They define participants and necessary majorities and also define the point of time in which an amendment comes into force. All these elements of amendment remain in doubt in the case of "informal" amendments.

Furthermore, a constitutional view of the Charter requires the participation of the international legal community at large in Charter amendments. While states are presently the only community members entitled to cast their vote, they nevertheless must take account of the views of the other members, especially in matters of particular concern to such members. A free and open discussion of the constitutional issues at issue is necessary to enable these non-governmental actors to form, clarify, and voice their opinions.

The question of amendment highlights the distinction between treaty and constitution which is crucial to my argument. If the parties agree, a treaty may be amended by a rule of customary law even if the text of the treaty says otherwise. There is nothing in general international law to prevent the parties from amending a treaty provision in any way they like. A constitution, in contrast, establishes institutions which by their very nature can only act under, and according to, the constitution which has given life to them. By adopting the constitution, the members of the respective community place themselves under its protection, and accept the corresponding restrictions. Henceforth, their capacity in constitutional matters is limited to the role assigned to them by the constitution.

I conclude that the Charter, as constitution of the international community, can only be amended in the procedures provided for in Articles 108 and 109. "A constitution is no soil for customary law."249

Can constitutional law that is not laid down expressis verbis in the Charter be amended? There is a symbiotic existence of written and unwritten constitutional law. Accordingly, constitutional law implicitly

248. See, e.g., U.S. CONST. art. V.

249. Christian TOMUSChAT, VerfasSUNGSGEWOHNHEITSREChT? EINE UNTERSUCHUNG ZUM STAATSRECHT DER BUNDESREPUBLIK DEUTSCHLAND 144 (1972). See also Jean-Paul Jacqué, La Constitution de la Communauté Européenne, 7 REVUE UNIVERSELLE DES DROITS DE L'HOMME 397, 403 (1995) ("Le caractére constitutionnel des traités se manifeste essentiellement dans l'exclusion du jeu des règles de droit international en ce qui concerne la révision des traités .... Un fort courant exclut toute révision coutumière des constitutions écrites en s'appuyant sur l'idée que les auteurs de la constitution, lorsqu'ils ont prévu un mode spécifique de révision, ont entendu exclure tout recours à la coutume constitutionnelle."). 
incorporated by the Charter can be amended in the procedure provided for in Articles 108 and 109. If one wants to change the Charter, no other procedure is admissible. However, to the extent that, under the reign of the Charter, constitutional rules have been concretized in special treaties (like the 1969 Vienna Convention on the Law of Treaties), they can be amended according to the relevant rules. So too, customary rules of constitutional rank, which have been generated since 1945 in accordance with the Charter, cannot mandatorily be subjected to its amendment procedure. The same holds true for the constitutional law of the "world order treaties" concluded under the legal umbrella of the Charter. They can be amended according to their own rules and by way of customary law. If, however, an amendment to the Charter were to lead to a conflict between an earlier extra-Charter constitutional rule and the amended Charter, the latter would prevail (Article 103 of the Charter).

Article 53 of the Vienna Convention on the Law of Treaties defines a norm of jus cogens as one "accepted and recognized by the international community of States as a whole ... which can be modified only by a subsequent norm of general international law having the same character." As constitutional law-making is a perfect expression of the general will of the international community, jus cogens may be created and modified through Charter amendment, regardless of whether the norm in question is presently pronounced in the Charter or not.

Furthermore, it is desirable that the Charter, as a constitution, pictures as completely as possible the constitutional law presently in force. The procedure of Articles 108 and 109 can be used to supplement the text of the Charter with rules already belonging to the body of constitutional law of the international community.

A number of constitutions, particularly those of some European states, declare some of their provisions to be unamendable. ${ }^{250}$ Their authors regarded them as so pivotal to their conception of the constitution that they simply prohibited their amendment. If a people wants to do away with these provisions, it has to establish an altogether new constitution (something it always has the power to do). In this case, however, it cannot claim identity of the old and the new constitutional regime are identical.

250. For a comparative survey, see Peter Häberle, Verfassungsrechtliche Ewigkeitsklauseln als verfassungsstaatliche Identitätsgarantien, in RECHTSVERGLEICHUNG, supra note 83, at 597. See also Hans-Ulrich Evers, Comment on Art. 79(3) of the Basic Law, in 7 BONNER KOMMENTAR ZUM GRUNDGESETZ, art. 79(3), paras. 23-35 (Rudolf Dolzer gen. ed., 2d ed. 1982). 
The most prominent example of such an effort to make future generations honor certain constitutional values and institutions is, perhaps, Article 79, paragraph 3 of the (West) German Constitution of 1949.251 It was written against the backdrop of the experience of the Weimar Constitution of 1919 which had made it easy for Hitler to establish his dictatorship under the guise of constitutional legitimacy. But the Grundgesetz was not the first constitution to tread such a path. Article 112, paragraph 1 of the Constitution of Norway of 1814, which is still in force, states that an amendment "must never contradict the principles embodied in this Constitution, but solely relate to modifications of particular provisions which do not alter the spirit of the Constitution." Similar provisions were adopted by the constitutions of Ecuador (1861) and Greece (1864). Peter Häberle distinguished the following types of Ewigkeitsklauseln, or "eternity clauses": (1) clauses protecting the "spirit" of a constitution, i.e., its fundamental principles, and (2) clauses protecting certain specified principles (for instance, the republican form of government, human rights, the separation of powers, or federalism). There has been a gradual expansion of the scope of constitutional features thus protected. Today, democracy, human dignity and human rights are commonly regarded as the foundation of constitutionalism which may not be altered. ${ }^{252}$ Many constitutions past and present have copied the guarantee of the republican form of government inserted in the French Constitution of 1875 in 1884 . These include the constitutions of Brazil 1891, Portugal 1911, China 1923, Turkey 1924 and 1961, Italy 1947, France 1958). A comprehensive catalogue of prohibitions is set out in Article 110, paragraph 1 of the Greek Constitution of 1975 and Article 290 of the Constitution of Portugal of 1976. Similarly, Article 4 of the Turkish Constitution of 1982 makes the essence of the constitution unamendable. ${ }^{253}$ The

251. According to the provision, an amendment is inadmissible "which touches upon the subdivision of the Federation in States, the principal participation of the States in [federal] legislation, or the principles laid down in Articles 1 and 20." Article 1, on its part, mainly protects human dignity and declares the fundamental rights listed in the following articles to be law directly binding on the legislative, executive and judicial powers. Article 20 describes Germany as a democratic and social federation.

252. See Häberle, supra note 250 , at 600-09.

253. See also U.S. CONST. art. V in fine: "Provided that ... no State, without its Consent, shall be deprived of its equal Suffrage in the Senate." This provision makes the constitution, as James Bryce said, "in one respect virtually, if not technically, unchangeable." BRYCE, CONSTITUTIONS 5 (1905). For a discussion of the Austrian Constitution of 1920/1929 (as amended), Article 44(3) of which requires a referendum for a Gesamtänderung der Bundesverfassung, or change of fundamental principles, see Siegbert Morscher, Die Hierarchie der Verfassungsnormen und ihre Funktion im Grundrechtsschutz in ÖSTERREICH, 1990 EUROPÄISCHE GRUNDRECHTE-ZEITSCHRIFT 454, 468-70. For a discussion of the Spanish Constitution of 1978, Article 168(1) of which requires a two-thirds majority of both chambers 
Constitution of the Republic of Korea of 1948, as revised in 1954, and the Constitution of the Republic of Korea of 1960 (Article 98) provided that, inter alia, the form of government and the principle of the sovereignty of the people could not be changed. Although the present South Korean constitution lacks a respective provision, the existence of substantive limits of the power of constitutional amendment is generally acknowledged. ${ }^{254}$ The same is true for Japan where most scholars believe that the fundamental principles of the constitution (popular sovereignty, fundamental rights, and pacifism $)^{255}$ cannot be changed through the process of amending the constitution as determined in Article $96 .{ }^{256}$ In Switzerland, similar views about ultimate limits of constitutional amendment have become dominant. ${ }^{257}$

In recent years, two decisions of the European Court of Justice 258 gave rise to a discussion of whether there are certain substantive limits on the power of member states of the European Communities to amend the founding treaties. Some argued that the existence of such limits would suggest a development of an independent community system, the basics of which are no longer within the member states' reach. ${ }^{259}$ Professor Herdegen has come to the conclusion that, inter alia, an amendment abolishing the European Parliament or the European Court of Justice would be inadmissible. ${ }^{260}$

of the Cortes Generales for the amendment of certain fundamental rules, see Pedro de Vega, Das Verfahren der Verfassungsänderung in der spanischen Rechtsordnung, in SPANISCHES VERFASSUNGSRECHT 91, 104-08 (Antonio López Piña ed., 1993).

254. See Bongkun Kal, Der Einfluss der Grundgesetzes auf koreanisches Verfassungsrecht, in 40 JAHRE GRUNDGESETZ: ENTSTEHUNG, BEWÄHRUNG UND INTERNATIONALE AUSSTRAHLUNG 299, 310 (Klaus Stern ed., 1990).

255. See JAPAN CONST. pmbl., arts. 1, 9, 11, and 97.

256. This information was kindly provided by Professor Norikazu Kawagishi (Waseda University, Tokyo).

257. See Arthur Haefliger, Die Hierarchie von Verfassungsnormen und ihre Funktion beim Schutz der Menschenrechte: Landesbericht Schweiz, EUROPÄISCHE GRUNDRECHTEZEITSCHRIFT, Nov. 30, 1990, at 474, 477-78; Häberle, supra note 83, at 139, 169 n.100.

258. See Case 1/91, Opinion Delivered Pursuant to the Second Subparagraph of Article 228(1) of the E.E.C. Treaty, 1991 E.C.R. I-6079; Case 1/92, Opinion Delivered Pursuant to the Second Subparagraph of Article 228(1) of the E.E.C. Treaty, 1992 E.C.R. 1-2821.

259. See Matthias Herdegen, Vertragliche Eingriffe in das "Verfassungssystem" der Europäischen Union, in 1 FESTSCHRIFT FÜR ULRICH EVERLING, supra note 87, at 447, 456. See also Roland Bieber, Les limites matérielles et formelles à la révision des traités établissant la Communauté européenne, 367 REvUE DU MARCHÉ COMMUN ET DE L'UNION EUROPÉENNE 343, 346-49 (1993). But see Markus Heintzen, Hierarchisierungsprozesse innerhalb des Primärrechts der Europäischen Gemeinschaft, 1 EUROPARECHT 35, 42-45 (1994).

260. See Herdegen, supra note 259 , at 461 . See also Jacqué, supra note 249 , at 404 , and Bieber, supra note 259, at 349 (declaring as inadmissible a diminution of fundamental rights and freedoms recognized by the E.U.; of democratic guarantees like the institution of the European Parliament, the direct election of its members, or the degree of its participation in the legislative process; and of judicial guarantees like the existence of the Court of Justice of the 
While in Germany the restrictions imposed by Article 79, paragraph 3 of the Basic Law are generally attributed to the influence of Carl Schmitt's thoughts, ${ }^{261}$ the much older distinction between pouvoir constituant and pouvoirs constitués, as systematized by Sieyès. This distinction implies that the institutions established by a constitution are not at liberty to take the place of the original constituent power and to change the essence of the constitution: "un pouvoir institue (réparti sur plusieurs autorités) qui, subordonné au constituant, ne saurait ni méconnaître la substance de la Constitution ni encore moins l'abroger .... II ne peut s'exercer [le pouvoir de révision] que pour préserver la Constitution et la rendre plus effective."262 Even when the French Constitution of 1793 declared that a people always has the right to change its constitution, ${ }^{263}$ that right did not apply to the fundamental principles enshrined in the Declaration of the Rights of Man. ${ }^{264}$ As Konrad Hesse said:

In any case a constitutional amendment requires that those rules are preserved which constitute the identity of the constitution .... 'Amendments' which would destroy this identity and thus bring about discontinuity are inadmissible. In reality, in that case constitutional law is not amended but created. Outside the law of the hitherto valid constitution, that constitution is replaced by a new one. ${ }^{265}$

European Communities, the effect of its decisions, and the access of individuals to the Court).

261. See SCHMTT, supra note 9, at 25-28 (arguing that the pouvoir constitue does not have the power to change the "fundamental political decisions determining the substance of a constitution" as made by the pouvoir constituant). For Schmitt's concept of constitution, see supra note 9 and accompanying text.

262. GREWE \& RUIZ FABRI, supra note 168 , at 50 . Accordingly, as to the power to amend the constitution (pouvoir de revision) a distinction is made between a pouvoir constituant originaire and a pouvoir constituant dérivé ou institué. That clauses like Article 79(3) of the German Constitution can be based on very different constitutional concepts (ranging from $\mathrm{C}$. Schmitt's to those of natural law), is emphasized by Häberle, supra note 250, at 614 n.67.

263. See supra note 178.

264. See Hofmann, supra note 56, at 295. See also EMER DE VATTEL, I LE DROIT DES GENS OU PRINCIPES DE LA LOI NATURELLE APPLIQUÉS À LA CONDUITE ET AUX AFFAIRES DES NATIONS ET DES SOUVERAINS (1798), ch. 3, sec. 34 (M.P. Pradier-Fodéré ed., 1863), and the distinction between articles réglementaires and articles fondamentaux in the French Constitution of 1814. The majority of scholars was of the opinion that only the former, but not the "fundamental" rules could be amended by the legislature. See Evers, supra note 250, at para. 23.

265. Hesse, supra note 88, at 12. 
In the same line of thought, the Italian Constitutional Court recognized in 1988 implicit limitations of the amending power resulting from the inviolability of fundamental constitutional principles. ${ }^{266}$

The written text of the Charter does not contemplate any ultimate bounds to Charter amendments. Articles 108 and 109 are concerned with procedure, not with substance. However, in the same way that positive prohibitive rules protecting the very essence of a constitution have to be regarded as declarative ${ }^{267}$ there are also unwritten limits-" "for a body entrusted with the task of amending a constitution, the 'spirit' of the constitutional order is intrinsically inviolable." ${ }^{268} \mathrm{~A}$ constitutional reading of the Charter reveals that the document is based on certain values and principles most of which are set out in the Preamble and Articles 1 and $2 .^{269}$ Deprived of them, the Charter would cease to be what it is today. ${ }^{270}$ Constitutional change of a legal system committed to individual freedom, and the restriction and rationalization of governmental power, is inherently limited by the responsibility for maintaining this order of liberty and confined power. ${ }^{271}$ As Louis Henkin put it, "[a]mendments must not be such as to derogate from the commitment to constitutionalism."272 Consequently, Articles 108 and 109 do not authorize member states to abolish, for instance, the commitment of the international community to "fundamental human rights" or to "the dignity and worth of the human person," or the principle of sovereign equality of states, or the prohibition of the use of force. Such "amendments" would result in a legal order so different from the constitution associated with the name of the United Nations to such an extent that the latter would have to be regarded as discontinued. The inadmissibility of certain amendments does not follow from the fact

266. Corte Cost., Dec. 15, 1988, Dec. No. 1146, 89 Racc. uff. Corte Cost. 627, 632-33, reprinted in 33 Giur. It. II, pt. 1, at 5565, 5569 (1988) (with a comment by Sergio Bartole). See GREWE \& FABRI, supra note 168 , at 57-58.

267. See Häberle, supra note 250, at 612.

268. Häberle, supra note 250, at 613. See also id. at 597.

269. For the close relationship between constitutional preambles and rules prohibiting certain amendments, see Häberle, supra note 250 , at 614 . For the normative force of preambles, see Häberle, Präambeln im Text und Kontext von Verfassungen, in RECHTSVERGLEICHUNG, supra note 83, at 176, 188-90, 203-05, 207-08. See also SMEND, supra note 6, at 108-09, 158, and SCHMITT, supra note 9, at 25. For a recent analysis of the preamble of the U.N. Charter, SEe DIE PRÄAMBEL DER UN-CHARTA IM LICHTE DER AKTUELLEN VÖLKERRECHTSENTWICKLUNG (Stephan Hobe ed., 1997).

270. For the notion of "fundamental constitutional principles," or "structural principles," see Kurt Eichenberger, Vom Umfang mit Strukturprinzipien des Verfassungsstaates, in VERFASSUNGSSTAATLICHKEIT: FESTSCHRIFT FÜR KLAUS STERN 457 (Joachim Burmeister ed., 1997).

271. See Scheuner, supra note 23, at 180.

272. HENKIN, supra note 20 , at 10. 
that the relevant norms possibly "preceded" the Charter but from the outstanding importance of those norms in the constitutional order established by it. In that sense, one may speak of a hierarchy of constitutional law of the international community.

\section{E. Freedom and Restraint of Security Council Reform}

If, therefore, the bodies endowed with the power to amend the Charter, as pouvoirs constitués, ${ }^{273}$ do not enjoy unlimited freedom of action, the question follows whether the Charter sets constitutional limits to a reform of the Security Council. This has been a matter of intense discussion since 1992. For here, in contrast to the substantive principles mentioned in the preceding section of this article, one cannot argue that restrictions of the amendment power directly follow from an implied obligation of member states to preserve the "core identity" of the Charter. Fundamental commitments of the international community do not seem to be involved in the case of provisions on the procedure of one of the organs established by the Charter.

The functioning of the Council is, however, not an end in itself. Rather it is meant to foster the achievement of certain purposes, the most important of which is the maintenance of international peace and security. Accordingly, one can say that if a reform of the Council made it impossible for the organization effectively to serve that purpose, such a reform would have to be deemed unconstitutional. To put it differently, because the Charter is the constitution of the international community, member states are obliged to maintain a mechanism with a certain minimum ability to safeguard international peace. This implies that the bodies which have been entrusted with Charter amendment enjoy wide discretionary powers. The Charter does not make mandatory any specific kind of Council reform. This is, however, not to say that one is barred from offering advice based on constitutional considerations with regard to a restructuring of the Council and its voting procedure. The guiding idea is that a Council reform should advance as much as possible the aims and purposes of the international community as set out in the Charter. It should promote in particular the maintenance of international peace and the protection of the "dignity and worth of the human person." Of the many constitutionally admissible

273. Another term is pouvoir constituant dérivé or institué, as opposed to the pouvoir constituant originaire. See Vlad Constantineso, L'émergence d'un droit constitutionnel européen: Rapport de synthèse, 7 REV. UNIVERSELLE DES DROITS DE L'HOMME 445, 449 n.32 (1995). 
amendments some may better serve these goals, and some may be more in line with the general Charter concept of international relations, than others. It seems to be of central importance to develop a more effective system of "global governance" based on a recognition of the different indispensable contributions states have to make, and are able to make.

In the present discussions about reform, governments have invoked a number of principles or "concepts" which they support with specific legal arguments. ${ }^{274}$ They maintain that these principles, which lead to different and partly incompatible types of Council reform, are either explicitly pronounced in the Charter or follow from a systematic reading of the instrument.

The principle to which governments refer most often is that stated at the very beginning of Article 2 of the Charter-the principle of the sovereign equality of U.N. member states. A related notion is that of the representativeness of the Council. Representativeness seems a corollary of respect for equality. It may amount to more than that, however, because a body composed of states cannot be called representative if it does not reflect, to some degree, inequalities within its constituency. The concept of a "democratic international society" is advanced by developing countries claiming a better representation on the Council. In light of the main purposes of the U.N., including the maintenance of international peace and security and the promotion of "social progress and better standards of life in larger freedom", 275 and in light of the Charter's goal of providing the best possible structures and procedures for attaining their goals, "effective governance" may be another (constitutional) principle relevant to Security Council reform. Finally, a closer look at the respective roles allocated to the General Assembly, the Security Council and the International Court of Justice appears to reveal a rudimentary system of checks and balances, or constitutional control, in which a reformed right of veto of the permanent members of the Council should be accorded its proper place.

But do the principles and concepts in question, regardless of their content and legal status, permit us to reach beyond the status quo?

274. See Report of the Open-ended Working Group on the Question of Equitable Representation on and Increase in the Membership of the Security Council and Other Matters Related to the Security Council, U.N. Doc. A/50/47, at 5 (1996) ("[The Group] again recognized that the principles of the sovereign equality of all Members of the United Nations, equitable geographical distribution and contribution to the maintenance of international peace and security, as well as to the other purposes of the Organization, should guide the work on the reform of the Security Council .... [I]t reiterated that the concepts of transparency, legitimacy, effectiveness and efficiency should also be taken into account in this context as should, in the view of a large number of delegations, the concept of democracy.").

275. U.N. CHARTER pmbI. 
Sovereign equality (or equality of constitutional status) is a principle not to be found in the Charter in a pure or abstract form but only as that amalgam which is the outcome of the precise allocation of rights and responsibilities defined by the Charter. The Charter has, in fact, newly defined the classical notion of sovereign equality to accommodate the needs of a world "determined to save succeeding generations from the scourge of war." 276 Accordingly, one cannot assert that there is a conflict or contradiction between that principle on the one hand, and limited access of member states to the Council and the veto power of the permanent members on the other hand, which should be remedied through Charter reform. Neither can the principle of sovereign equality, as it stands today, prescribe exactly how rights and responsibilities should be allocated in the future.

The foregoing does not, however, preclude a distinction and critical appraisal of different elements of this consolidated principle. The Charter, it is true, is the ultimate point of reference. But its letter is grounded on and influenced by assumptions and premises which interpretation may not ignore. As regards the veto, the drafting history of the Charter reveals that it was invented and understood to be an exceptional device, a divergence from the ideal of full equality which could not be realized under the prevailing circumstances. In a discussion of alternative modes of Council reform and their relative merits, one is therefore not prevented from giving more weight to one element than to another, nor is one prevented from declaring one element, and not another, to represent the essence of a principle. One can also oppose and balance the different principles mentioned above in order to suggest, in the end, a reform of the Security Council which can be regarded as a constitutionally sound progressive development of the Charter.

In 1948, Philip C. Jessup pointed out that "[i]t is supremely difficult to find acceptable formulae [for inequalities in voting power and in representation] in political organizations, where the prestige factor and problems of political existence may be at stake."277 It remains to be seen whether it is possible to complement a set of political, and therefore shifting, "formulae" with constitutional considerations able to guide the allocation of responsibilities and rights to individual members of the international community. ${ }^{278}$

276. See supra note 188 and accompanying text.

277. PhILIP C. JESSUP, A MOdERN LAW OF NATIONS: AN INTROdUCTION 30 (1948).

278. For a detailed discussion of the questions mentioned here, see the author's forthcoming book, supra note *, ch. 10. 


\section{F. Legal Persons Other than States as Addressees of Security Council Decisions}

In situations of civil strife in a country, the Security Council now almost routinely appeals to all sides concerned. It does not appeal only to the government entitled to act on behalf of the State, or the entity which has undertaken the commitments set forth in the Charter. Still, until recently the Council had never used the instrument of a binding decision vis-à-vis a non-State entity. ${ }^{279}$ This changed in the course of the Yugoslav crisis, when the Council, acting under Chapter VII, made demands on "the Bosnian Serb forces" and "the Bosnian Serb party," respectively. ${ }^{280}$ This Article has shown that the Council was fully entitled to make such demands, as the Charter is binding upon all members of the international community. This includes belligerent and insurgent bodies whose (limited) international legal personality is generally acknowledged. Also included are intergovernmental organizations, regardless of whether all of their members have ratified the Charter. The Security Council has adopted a practice of "calling upon" international organizations to act in accordance with its resolutions. Although the Council does not use the words "decides that" at the beginning of the relevant paragraphs, its "call" is more than just a political appeal, as legal consequences are attached to it. ${ }^{281}$ In fact, the Council presupposes that intergovernmental organizations are generally required to comply with Council resolutions-a responsibility which can only be based on the Charter. ${ }^{282}$

279. See Tomuschat, supra note 68 , at 255.

280. See S.C. Res. 1004, U.N. SCOR, 50th Sess., 3553rd mtg., U.N. Doc. S/RES/1004 (1995) and S.C. Res. 1010, U.N. SCOR, 50th Sess., 3564th mtg., U.N. Doc. S/RES/1010 (1995). See also S.C. Res. 1022, U.N. SCOR, 50th Sess., 3595th mtg., U.N. Doc. S/RES/ 1022 (1995), which temporarily excluded "the Bosnian Serb party" from the suspension of measures imposed by the Council; and S.C. Res. 1127, U.N. SCOR, 52nd Sess., 3814th mtg., U.N. Doc. S/RES/1127 (1997), which provided for sanctions against the Uniao Nacional para a Independencia Total de Angola (UNITA).

281. See, e.g., S.C. Res. 748, U.N. SCOR, 47th Sess., 3063 mtg., para. 7, U.N. Doc. S/RES/748 (1992) (Libya) ("The Security Council ... Calls upon . . . all international organizations, to act strictly in accordance with the provisions of the present resolution, notwithstanding the existence of any rights or obligations conferred or imposed by any international agreement or any contract entered into or any license or permit granted prior to 15 April 1992."). See also S.C. Res. 841, U.N. SCOR, 48th Sess., 3238th mtg., paras. 9, 12, U.N. Doc. S/RES/917 (1993) (Haiti).

282. That intergovernmental organizations, although they have not ratified, and cannot ratify, the Charter, are bound by it was expressed by Article 30(6) of the Vienna Convention on Treaties with and between International Organizations, supra note 175, which stipulates that " $[t]$ he preceding paragraphs are without prejudice to the fact that, in the event of a conflict between obligations under the Charter of the United Nations and obligations under a treaty, the obligations under the Charter shall prevail." 
Inasmuch as the activity of individuals can have a bearing on the maintenance of international peace and security, they, too, can be addressees of Security Council decisions. The same applies to associations and corporations established under private law, including multinational corporations whose role in international affairs is ever more important. It is not impossible to conceive of a situation in which the conduct of such corporations would be of critical importance to the preservation of world peace. In such a case, the Council may directly address the corporation in question. ${ }^{283}$

\section{G. Admission and Expulsion of U.N. Member States}

If it is true that today all states are equally obliged to heed the rules of the Charter, then all states are also equally entitled to membership in the organs of the international community. The "principle of universality" of the U.N., understood as the legal basis for such entitlement, follows from the constitutional character of the Charter, which itself is founded on the principle of sovereign equality. Article 4, paragraph 1 of the Charter must therefore be read as entitling every sovereign and "peace-loving" state to membership. ${ }^{284}$ The latter requirement is met if a state credibly accepts the fundamental constitutional principles of the international community as enshrined in the Charter and other instruments. This means that every U.N. member state is obliged to vote in favor of an applicant's admission if these conditions are met. ${ }^{285}$ By joining the organization, a state can take part in the constitutional development of the international community. This right to membership is particularly momentous if one realizes that today "in most instances membership in the United Nations determines the existence of a State,

283. Such authority of the Council may be regarded as a form of international "public executive and judicial control" of private economic activities which Professor Friedmann some thirty years ago expected to be exerted in "a further stage in international legal organisation." See FRIEDMANN, supra note 26, at 231 (1964).

284. See Conditions of Admission of a State to Membership in the United Nations, 1947-48 I.C.J. 57, 71 (May 28) (Alvarez, J., indiv. op.). See also the amendments and comments of states concerning ch. III, para. 1 of the Dumbarton Oaks Proposals; THE UNITED NATIONS CONFERENCE: SELECTED DOCUMENTS, supra note 243, at 111-12.

285. The same view was already held with regard to the League of Nations. See WALTHER SCHÜCKING \& HaNS WeHBERG, 1 Die SATZUNG DES VölKERBUNDES 283 (3d ed. 1931); W. STRUB, DIE MITGLIEDSCHAFT IM VÖLKERBUND 87-90 (1927). A motion of Argentina of 1920 providing for an automatic membership of all sovereign states was adjourned. See STRUB, supra, at 90 n.2. But see Scelle, supra note 136, at 137 ("Mais l'admission d'aucun État ni Nation n'est obligatoire pour la Société, dans l'état actual de sa constitution juridique ") (emphasis added). 
irrespective of any additional unilateral acts of recognition on the part of States."286

Since the "package deal" of $1955^{287}$ and, subsequently, the solution of the micro-state question (to the effect that a state is admitted without regard to the size of its territory or population, or the strength of its economy or military), the practice of the U.N. has generally been in accordance with the proposition just mentioned. ${ }^{288}$ U.N. practice regognizes a constitutional right to membership in the U.N.-a right already implied by the words "open to all other peace-loving states" in Article 4, paragraph 1.

The most notable exceptions to the principle of according membership to states that desire it are the cases of the divided states: Germany, Korea and Vietnam. These states were the focal points of East-West confrontation, where each side tried to prevent the other from expanding its sphere of influence. In fact, the "package deal" had only been made possible by not including the applications of the two Vietnams and the two Koreas (no German applications were pending at the time). ${ }^{289}$ The states in question, whose independent statehood was generally denied by either the Western or the socialist block, were admitted to the U.N. "only after the conflicting claims of the two sides had been formally adjusted, either in favour of division (in the view of one side possibly only on a provisional basis) or in favour of reunification." ${ }^{290}$ With the explicit approval of the Four Principal Allied Powers, the two German states were admitted in 1973 after they had newly defined their relations in a treaty. An earlier effort to join the U.N. by the German Democratic Republic, which had expressly asserted a "right

286. JoHN DUGARD, RECOGNITION AND THE UNITED NATIONS 167 (1987).

287. See Leo Gross, Progress towards Universality of Membership in the United Nations, 50 AM. J. INT'LL. 791 (1956).

288. Since 1991, some states (Marshall Islands, Federated States of Micronesia, Monaco, Andorra, Palau) have even been admitted whose formal sovereignty is not beyond doubt, given their obligations to third states. For details of the legal status of Monaco and Andorra, see JORRI C. DUURSMA, FRAGMENTATION AND THE INTERNATIONAL RELATIONS OFMICRO-STATES: SELFDETERMINATION AND STATEHOOD 261, 316 (1996). For the question of "micro-states and the U.N.," see id. at 134-42.

289. See the joint draft resolution of Nov. 16, 1955) ("The General Assembly, . . 2. Requests the Security Council to consider, in the light of the general opinion in favour of the widest possible membership of the United Nations, the pending applications of all those countries about which no problem of unification arises ...") (emphasis added). See Gross, supra note 287, at 798, and Konrad Ginther, Comment on Art. 4, in THE CHARTER OF THE U.N., supra note 41 , at $158,161,166$.

290. Ginther, supra note 289 , at 166. 
to membership," failed because of the opposition of the United States, the United Kingdom, and France. ${ }^{291}$

One has to distinguish these cases, in which admission was delayed or denied because of the political and ideological antagonism between member states, from those in which U.N. organs did not recognize aspirant states because they had come into being as a result of a violation of the right of self-determination, the prohibition of aggression, or the prohibition of racial discrimination and apartheid. ${ }^{292}$ While this latter course of action is in line with the Charter, one can still conceive of a situation in which an entity has, over time, stabilized its independent political existence to such an extent that, in spite of its illegal birth, it can no longer be refused participation in the organs of the international community.

My interpretation of Article 4, paragraph 1 of the Charter does not, however, make the granting of state membership in the U.N. automatic. First, there must be a procedure to ascertain whether the criteria of independent statehood and willingness to carry out the Charter obligations are met. Second, at this stage of the constitutional development of the international community an obligation actively to participate in the work of the community organs cannot yet be assumed - a state is free to decide not to apply for membership in the U.N.

Just as a state can presently still abstain from becoming a member of the U.N., it can also leave the organization or temporarily withdraw from its institutions. Although the Charter does not contain a clause specifically providing for such withdrawal, it was already understood at San Francisco that a state could not be obliged to remain in the organization against its will. ${ }^{293}$ While it is not clear whether a member state was thought to be able to divest itself of the obligations set out in

291. See Application for Admission of the German Democratic Republic to the U.N., Feb. 28,1966 , together with accompanying declarations and memoranda, reprinted in XIV DOKUMENTE ZUR AUBENPOLTIK DER DEUTSCHEN DEMOKRATISCHEN REPUBLIK, pt. 1, at 639-91 (1970); Letter of the Governments of France, Great Britain and the United States to the President of the Security Council, March 16, 1966, reprinted in 21 EUROPA ARCHIV D 196 (1966). For the position of East Germany, see also WOLFGANG SPRÖTE \& HARRY WÜNSCHE, DIE VEREINTEN NATIONEN 18-21 (1971).

292. For the cases of Biafra, Katanga, Rhodesia, South Africa's "independent national states," and the "Turkish Republic of Northern Cyprus," see DUGARD, supra note 286, at 84$111,154$.

293. See VERdRoss \& Simma (3d ed.), supra note 41, at 85; Karl \& Mützelburg, Comment on Art. 108, in THE CHARTER OF THE U.N., supra note 41, at 1175-76. 
the Charter by withdrawing from the organization ${ }^{294}$ (a view not supported by Article 2, paragraph 6), a constitutional view of the Charter precludes this conclusion. For the time being, a state is free not to exercise its constitutional right to participate in the work of the community organs. In 1950, for example, the Soviet Union temporarily withdrew from the Security Council and other U.N. organs in reaction to the majority's refusal to replace the Kuomintang Government with that of the People's Republic as representative of China. ${ }^{295}$ In 1965, Indonesia decided to quit the organization. ${ }^{296} \mathrm{~A}$ state cannot leave the international community, however, and it cannot escape the rules set out in its constitution. Thus, since state participation in the work of the community organs still relies on state consent, one can say that such participation is of a contractual nature, whereas a state's commitment to the substantive rules of the Charter and its subjection to the authority of the community organs are not.

An understanding of the U.N. Charter as a constitution also has consequences for its Articles 5 and 6 . Just as a state cannot evade its obligations under the constitution of the international community, it cannot be expelled from the constitutional community as such. This membership in the international community has to be distinguished from a state's participation in the work of the community organs. A (temporary) suspension "from the exercise of the rights and privileges of membership," as provided for in Article 5 of the Charter, is acceptable from a constitutional point of view. However, it seems inadmissible permanently to exclude a state from the organic structure of the community as established by the Charter. To prevent a state permanently from participating in the work of the community organs is incompatible with the very idea of an international community living under a constitution. In a domestic context, punishing a lawbreaker by

294. See Report of Rapporteur of Commission I to Plenary Session, San Francisco Conference, June 24, 1945, reprinted in THE UNITED NATIONS CONFERENCE: SELECTED DOCUMENTS, supra note 243, at 595-96. See also the letter to the Secretary-General of March 8,1965 on the occasion of Indonesia's withdrawal from the U.N., in which the U.K. Government, referring to the terms of Article 2(6) of the Charter, declared "that a State which had expressed an intention to withdraw from the Organization nevertheless remained bound to observe the fundamental principles embodied in Article 2 of the Charter relative to the maintenance of international peace and security." U.N. Doc. A/5910 (S/6229) (1965), quoted in 1964 U.N.Y.B. 191. In a note verbale of May 13, 1965 addressed to the Secretary-General, the Italian Government observed that "[no] State could by withdrawing from the Organization avoid some of the fundamental obligations laid down in the Charter." U.N. Doc. A/5914 (S/6356) (1965), quoted in 1965 U.N.Y.B. 237.

295. See 1950 U.N.Y.B. 52, 74-77, 108-09, 415-16, 419-20.

296. See Egon Schwelb, Withdrawal from the United Nations: The Indonesian Intermezzo, 61 AM. J.INT'LL. 661 (1967); Yehuda Z. Blum, Indonesia's Return to the United Nations, 16 INT'L \& COMP. L.Q. 522 (1967). 
permanently withdrawing his political liberties (like his right to vote or to hold a public office) may be acceptable. But a state, as an entity representing an entire people in international relations, cannot infinitely be excluded from the community organs. This view is confirmed by the fact that in the history of the U.N. not a single state has been expelled from the organization. ${ }^{297}$ In the case of the Federal Republic of Yugoslavia (Serbia and Montenegro), the action taken by the Security Council and the General Assembly de facto amounts to a-legally questionable - suspension from the exercise of certain rights of membership. ${ }^{298}$

The early drafts of the Charter prepared by the U.S. Government contained no provisions for expulsion, and neither did the U.S. Tentative Proposals for a General International Organization of July 18, 1944 , which formed the basis of the Dumbarton Oaks conversations. The group responsible for drawing up the proposals was of the opinion that if the contemplated security system was to be effective, certain obligations-like the obligation to settle disputes peacefully-would have to be observed by all states, whether they were members of the organization or not. Member states should not be permitted to escape such obligations merely by withdrawing. It was considered undesirable for a state that had been expelled to regard itself as having been freed from its obligations as a member. ${ }^{299}$ At the same time, a major reason for including a provision for expulsion in the Covenant of the League

297. Various efforts aimed at an exclusion of Belgium, Israel, Portugal and South Africa. In 1974, a draft resolution recommending to the General Assembly the immediate expulsion of South Africa from the U.N. in compliance with article 6 of the Charter failed to be adopted by the Security Council because of the negative votes of the three Western permanent members. See 1974 U.N.Y.B. 109-15. See also FrANK ZEIDLER, DER AUSTRITT UND AUSSCHLUSS VON MITGLIEDERN AUS DEN SONDERORGANISATIONEN DER VEREINTEN NATIONEN 138-39 (1990).

In the League of Nations, neither in the case of the Japanese aggression against China, nor in the case of the Italian aggression against Ethiopia, was there a formal attempt at expulsion. It was only in 1939 , at a time when the League experiment had basically failed, that the Soviet Union was excluded. See Sohn, supra note 57, at 1386-90.

298. For discussion, see Yehuda Z. Blum, UN Membership of the "New" Yugoslavia: Continuity or Break?, 86 AM. J. INT'L L. 830 (1992); id., Reply [to letters to the editor-in-chief], 87 AM. J. INT'L L. 248 (1993) (arguing that Yugoslavia did not cease to exist as a subject of international law as a result of the secession of four of its six constituent republics). The contrary view (dissolution of the old Yugoslavia) is discussed in Vladimir-Djuro Degan et al., Correspondent's Agora: U.N. Membership of the Former Yugoslavia, 87 AM. J. INT'L L. at 240, 244, 246 (1993). For a detailed account of the events, see Marc Weller, The International Response to the Dissolution of the Socialist Federal Republic of Yugoslavia, 86 AM. J. INT'L L. 569 (1992). For the action taken by U.N. organs, see 1992 U.N.Y.B. 138, 1993 U.N.Y.B. 210. For the positions adopted by the United States and the United Kingdom, see also Marian Lash, Economic Sanctions and Other Measures, 87 AM. J. INT'L L. 614, 614-17 (1993) and 66 BRTT. Y.B. INT'LL. 618, 618-19 (1995), respectively.

299. See Ruth B. Russell, A History OF THE UnIted Nations Charter: THE Role OF THE UNITED STATES 1940-1945, at 362-63 (1958). 
of Nations, i.e. the extensive unanimity rule, was no longer present. ${ }^{300}$ Ironically, it was only at the insistence of the Soviet Union-the only state excluded by the League of Nations - that a provision on exclusion was incorporated into the Dumbarton Oaks Proposals. ${ }^{301}$

As had already been declared at the San Francisco Conference, ${ }^{302}$ Article 5 of the Charter provides an adequate and sufficient sanction if a state has breached the law of the constitution. ${ }^{303}$ Depending on the gravity of the violation, suspension may be inflicted for a longer or a shorter period of time. Only certain rights and privileges may be suspended, leaving others with the state in question. For these reasons, Article 6 should be removed from the text of the Charter. ${ }^{304}$

300. See C.W. Jenks, Expulsion from the League of Nations, 16 BRTT. Y.B. INT'L L. 155, 156 (1935) ("The clause [Article 16(4) of the Covenant] was introduced ... not because it was thought that the appropriate method of dealing with a covenant-breaking state is to expel it from the League of Nations and thereby to confess the complete inability of the League to restrain illegal conduct, but because it was thought that a state in breach of covenant might attempt to block systematically all League business by voting against every proposal under consideration.")

301. See Sohn, supra note 57 , at 1398-99.

302. See the comment made by the Dominican Republic regarding chapter five, section $B$, paragraph 3 of the Dumbarton Oaks Proposals: "It seems advisable that said sanction [i.e., expulsion] be eliminated, because, on the one hand, the character of the International Organization should be universal in principle, and on the other hand, the suspension of the exercise of the rights or privileges inherent in membership in the Organization, together with the sanctions provided for in Chapter VIII, Section B, paragraph 3, of the aforementioned Proposals, would at least assure all the effects of expulsion without offering any of its undesirable features." U.N. CONFERENCE, supra note 243, at 123.

Brazil and Ecuador submitted the following amendment to chapter three, paragraph 1 of the Dumbarton Oaks proposals: "No state may be expelled from the Organization...." Egypt recommended "to avoid ... any disposition aiming at expulsion of members." Referring to chapter five, section B, paragraph 3 of the Proposals, Belgium, Mexico, Norway, Uruguay and Venezuela likewise suggested to delete the clause dealing with expulsion. See id. at 111 $12,123-25$. For the respective discussions in Committee $I / 2$, in which a majority favored inclusion of such a clause in the Charter, see Report of Rapporteur (Membership) of Committee I/2 to Commission I on Chapter III, June 24, 1945, in id. at 507-09. Before, in the special subcommittee appointed to discuss withdrawal, suspension and expulsion, a motion approving the omission of a provision for expulsion had been carried by a vote of six to five. See Report of Rapporteur (Membership) to Committee $1 / 2$ on Meetings of the Special Subcommittee, May 22 and 23,1945 , in id. at 527.

For similar suggestions of the Inter-American Juridical Committee and states represented at the 1945 Inter-American Conference on Problems of War and Peace in Mexico City, see Sohn, supra note 57, at 1399-1400.

303. See also Hans Kelsen, The Old and the New League: The Covenant and the Dumbarton Oaks Proposals, 39 AM. J. INT'L L. 45, 49 (1945), and KELSEN, supra note 157, at 711-12, 714-15.

304. See also Charter of the Organization of American States, as amended Dec. 14, 1992, art. 9, in 33 I.L.M. 1005 (1994) (providing that a member state whose democratically constituted government has been overthrown by force may be suspended from the exercise of the right to participate in the sessions of the General Assembly and any other bodies of the organization); the Treaty on European Union, Feb. 7, 1992, art. f(1), O.J. (C 224) I (1992), as 


\section{CONCLUSION}

My theory of the existence of a constitution in the sphere of international law draws on the work of Alfred Verdross. Professor Verdross introduced a powerful notion whose time had not yet come when he first perceived it, which may explain his hesitancy to examine its consequences more fully. In the meantime, the scholars I have grouped together as belonging to the international community school began presenting evidence of the sociological foundations of a constitutional community. Although they embraced the concept of international constitutional law only cautiously, and although they ultimately, rejected the idea of the U.N. Charter as the constitution of the international legal community, their findings regarding the actual state of international law enabled me to take Professor Verdross' views a few steps further.

Scholars are increasingly coming to recognize "a gradual movement towards a universal constitutional system which can be described and analyzed in terms of law." $" 305$ But the place of the U.N. Charter in that system is not yet sufficiently understood. Those who believe in a broad "world constitutive process," 306 or an equally broadly defined "global constitutionalism," 307 will reject the view of the Charter as the written constitution of the international community as an antiquated revival of formalism and normativism. However, as the teachings of Smend and others have demonstrated, there is no inevitable conflict between the notion of a written constitution and that of a more inclusive constitutional process. The Charter can be seen as part of a larger process of building a world order of law and justice. It is neither an end in itself, nor a sufficient condition of such an order. Yet compared to the rather nebulous "cluster of various values, norms, procedures, regimes, institutions, and practices" supposedly comprising "global constitutionalism," 308 the Charter has the advantage of reliably provid-

amended by the 1997 Treaty of Amsterdam, available at <http.//www.bz.minbuza.nl/ english/treaties/tradam.html> (providing that certain membership rights may be suspended in the case of a "serious and persistent breach by a Member State" of the principles on which the

Union is founded, i.e., "the principles of liberty, democracy, respect for human rights and fundamental freedoms, and the rule of law"). Cf. the Treaty Establishing the European Community, Feb. 7, 1992, art. 236, 1 C.M.L.R. 573. As before, the treaties on the Union and the Communities do not provide for an exclusion of a member state.

305. Weller, supra note 8 , at 62-63.

306. For the respective views of the New Haven School, see supra text accompanying note 47.

307. See Richard A. Falk et al., Global Constitutionalism and World Order, in CONSTITUTIONAL FOUNDATIONS, supra note 185, at 3, 9 .

308. See Richard A. Falk, The Pathways of Global Constitutionalism, in CONSTITUTIONAL FOUNDATIONS, supra note 185, at 13, 14-15. 
ing, as a "visible document," an authoritative statement of both the fundamental rights and responsibilities of the members of the international community and the values to which this community is committed. Moreover, it also establishes clearly defined community institutions.

In applying the concept of a constitution to the international community, I have described an ongoing cumulative process in which empirical facts, beliefs and attitudes have forced us to revise our theory of the international legal system in ways already suggested by the norms of the Charter. However, perhaps there is less continuity than one would like to see. In fact, it may be that a scientific revolution as perceived by Thomas Kuhn is taking place, in which an older paradigm is overthrown and replaced by a new framework incompatible or even incommensurate with the old. Here, the old paradigm is an international law based on state sovereignty-a system of states perceived as possessing original, natural, and therefore unlimited legal powers, where a rule only becomes binding on a state because of its consent. In contrast, the new paradigm is international constitutionalism-the legal order of a community whose fundamental rules must be honored by every member of the community. If this is true, we cannot expect the "facts" and ideas marshaled in support of the old theory to be relevant to the new. The questions asked and answered in the new framework will have to be different from those of the old. Jarat Chopra has reminded us that Emmerich de Vattel, in his Law of Nations of 1758, attempted to make natural law more real, and inadvertently opened the door to the positivist project that defined so much of the following two centuries. ${ }^{309}$ Is today the idea of a universal constitution in the form of the U.N. Charter an analogous doctrine with comparable potential consequences?

A last point is worth considering. The American and the French Constitution, the prototypes of modern constitutions, resulted from a process of rationalization of the exercise of power. Self-conscious lawmaking was intended to make societal relations reliable and foreseeable.

Development of culture always presupposes an intensification of the division of labor and, thus, an increasing interdependence of groups situated at different places . . . . Increased division of labor and exchange require a higher degree of public safety, that is, more or less, legal security in the language of lawyers. This security, on its part, requires

309. See Jarat Chopra, Some Puzzles of International Society, 10 CAMBRIDGE REV. INT'L AFF. 23, 28 (Winter-Spring 1997). For the life and work of Vattel, see ARTHUR NUSSBAUM, A CONCISE HISTORY OF THE LAW OF NATIONS 156-64 (rev. ed. 1954). 
a higher regularity and reliability of societal relations. At the moment when local custom is not sufficient any more, this higher and more comprehensive form of rationality can only be achieved by subjecting the societal-particularly the political, economic and military-relations to a unified order which extends its scope territorially as well as in substance .... If eventually all inhabitants of a territory shall, directly or indirectly, be subjected to the ... entity of central decision, and if everybody shall contribute to the unity of the central force, the organization as a whole is in need of a comprehensive plan-a normative constitution. ${ }^{310}$

Heller's explanations are applicable to the idea of an international constitution. As in the case of national constitutions enacted in the past, the intensification of traffic and trade, the growing interdependence of people living at different places, and the ensuing need for legal security are the driving forces behind the process of constitutionalization.

But there is a decisive difference. Modern state constitutions are as much a result of the rationalization of the exercise of power as of the determination of citizens to secure a sphere of individual rights and liberties which the state must respect. ${ }^{311}$ In contrast, the international order is still so little developed that H.L.A. Hart considered it necessary to ask, "Is international law really law?"312 For this reason, one serious incentive for greater constitutionalism is missing in the international community as a community still dominated by states. Although there is a certain unease about the more active role that the Security Council has begun to play since the end of the Cold War, states do not feel the need to defend themselves against an international leviathan trespassing upon the rights of those who created it in order to protect them from each other. ${ }^{313}$ To the contrary, governments and the national elites supporting them are quite satisfied with the freedom they enjoy under traditional international law, which generally "speak[s] to governments the words that governments want to hear." 314 Only the international community at large, in particular the individuals whom international law (like all law) is meant to serve, can make international society

310. HELLER, supra note 10 , at 286-87, 306-07.

311. See id. at 307-09.

312. H.L.A. HART, THE CONCEPT OF LAW 209 (1961).

313. But see Weller, supra note 8 , at 61 (because international institutions "have arrogated much authority to themselves it will soon become a constitutional necessity to contemplate ways of ensuring that their activities are indeed based on a grant of authority by their constituents, that they comply with the rule of law and operate transparently and in a publicly accountable way.").

314. ALLOTT, supra note 1, at 296. 
"reconceive itself as a society, using social power, and especially legal relations, to bring about the survival and prospering of the whole human race." 315 History demonstrates that governments can be persuaded to take their place in a constitutional structure for the sake of peaceful relations and common survival. The possibilities for an international constitutional spirit are exemplified by the preamble of the 1951 Treaty of Paris Establishing the European Coal and Steel Community:

The Heads of Government and State,

... Considering that world peace can be safeguarded only by creative efforts commensurate with the dangers that threaten it,

... Resolved to substitute for age-old rivalries the merging of their essential interests; to create, by establishing an economic community, the basis for a broader and deeper community among peoples long divided by bloody conflicts, and to lay the foundations for institutions which will give direction to a destiny henceforward shared,

Have decided to create a European Coal and Steel Community .... ${ }^{316}$

315. Id. at 417 .

316. Treaty of Paris Establishing the European Coal and Steel Community, Apr. 18, 1951, pmbl., 261 U.N.T.S. 140. For the historical context, see Bardo Fassbender, Zur staatlichen Ordnung Europas nach der deutschen Einigung, 46 EUROPA ARCHIV 395, 397 (1991). 
HeinOnline --- 36 Colum. J. Transnat 620 (1998) 